\title{
Influence of the Gondwanide Magmatic Arc and Cape Fold Belt on the Karoo Basin - South Africa
}

\author{
Clyde Pitt Findlay III
}

Follow this and additional works at: https://researchrepository.wvu.edu/etd

\section{Recommended Citation}

Findlay III, Clyde Pitt, "Influence of the Gondwanide Magmatic Arc and Cape Fold Belt on the Karoo Basin South Africa" (2016). Graduate Theses, Dissertations, and Problem Reports. 5597.

https://researchrepository.wvu.edu/etd/5597

This Thesis is protected by copyright and/or related rights. It has been brought to you by the The Research Repository @ WVU with permission from the rights-holder(s). You are free to use this Thesis in any way that is permitted by the copyright and related rights legislation that applies to your use. For other uses you must obtain permission from the rights-holder(s) directly, unless additional rights are indicated by a Creative Commons license in the record and/ or on the work itself. This Thesis has been accepted for inclusion in WVU Graduate Theses, Dissertations, and Problem Reports collection by an authorized administrator of The Research Repository @ WVU. For more information, please contact researchrepository@mail.wvu.edu. 


\title{
Influence of the Gondwanide Magmatic Arc and Cape Fold Belt on the Karoo Basin - South Africa
}

\author{
Clyde Pitt Findlay III \\ Thesis submitted \\ to the Eberly College of Arts and Sciences \\ at West Virginia University
}

In partial fulfillment of the requirements for the degree of

Masters of Science In

Geology

Amy Weislogel, Ph.D., Chair

Tim Carr, Ph.D.

Jaime Toro, Ph.D.

Department of Geology and Geography

Morgantown, West Virginia

2016

Keywords: Karoo Basin, Gondwana, Permian, Triassic, Shale, Mudstone, Provenance, Geochemistry, Major Elements, Trace Elements, Rare Earth Elements, Sm-Nd, Subsidence Model, Foreland Basin Copyright 2016 Clyde Pitt Findlay III 


\section{ABSTRACT \\ Influence of the Gondwanide Magmatic Arc and Cape Fold Belt on the Karoo Basin - South Africa}

\section{Clyde Pitt Findlay III}

The Permian Ecca Group in South Africa preserves a thick succession of clastic basin fill, including mud-rich turbidite sequences and hemipelagic mudstone units. Provenance of mud influx into the basin is an important constraint for understanding the tectonic processes influencing regional basin development and distribution of organic-rich Lower Ecca Group mudstone and subsequent depositional style of the Upper Ecca Group turbidite systems. In this study, we interpret the Ecca Group mudstones were sourced by the Cape Fold Belt and Gondwanide Magmatic Arc based on geochemistry and mineralogy of 38 mudstone samples. Muscovite and high quartz content (average 32.9\%) indicate metamorphic and recycled sedimentary sources. Chemical index of alteration (CIA) values are greatest (CIA $=76-82$ ) and Index of Compositional Variability (ICV) is depressed (ICV $=0.5-0.8$ ) at the base of the Ecca Group, and indicate less weathering upsection. Rare earth element abundances display LREE enrichment and a negative Eu anomaly, and various trace element plots are consistent with mixing of sediment derived from Old Upper Continental Crust (OUC) and Young Differentiated Arc (YDA) terranes, such as the Cape Fold Belt and Gondwanide Magmatic Arc, respectively. Epsilon Nd and chondritic model ages are consistent with mixing of OUC and YDA sources. These results indicate that the southern Gondwanide Magmatic Arc and the Cape Fold Belt affected subsidence and sedimentation during early development of the Karoo Basin, and that the basin is a retroarc foreland basin. 


\section{Acknowledgments}

First and foremost I thank my wife, Jenny, for helping me through my master's degree. She not only kept me on track to finish writing this thesis, but supported me financially as well. I would also like to thank my advisor, Amy Weislogel, for introducing me to the Karoo project and guiding me through my research. I also thank my graduate committee, Tim Carr and Jaime Toro, for their support. This project would not have been possible without the help of my fellow classmates Matt McKay and Ben Johnson. Finally I would like to thank Harold Stowell and Liz Bollen at the University of Alabama, the GeoAnalytical lab at Washington State University, Actlabs, and the Shared Resource Facilities at West Virginia University for the use of their analytical facilities. 


\section{Table of Contents}

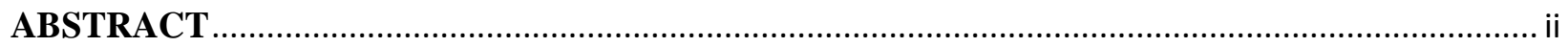

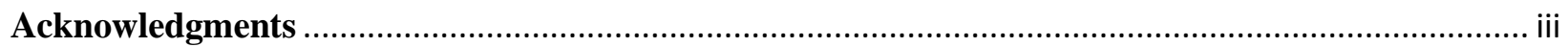

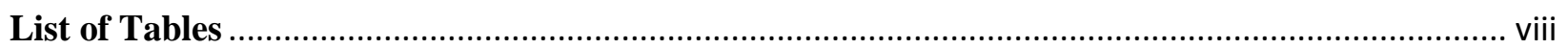

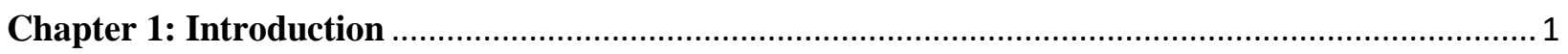

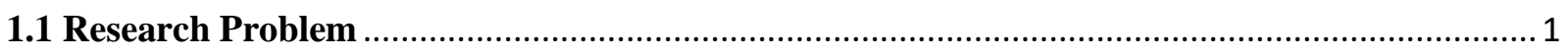

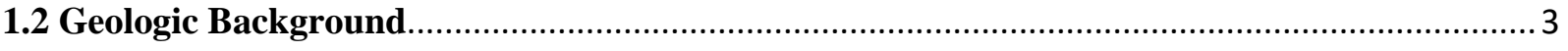

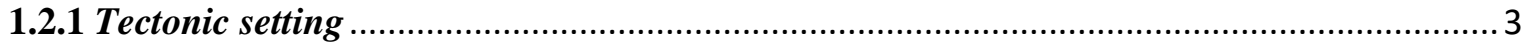

1.2.2 Karoo Basin Stratigraphy ...................................................................................... 4

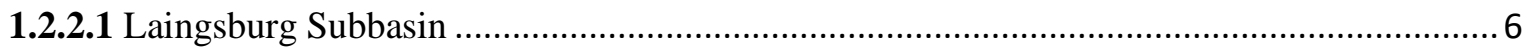

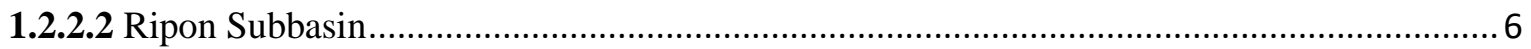

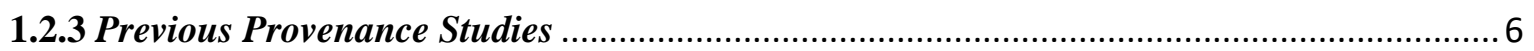

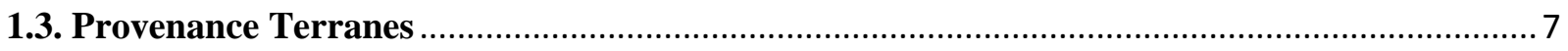

1.3.1 Kalahari Craton and Namaqua-Natal Metamorphic Province ......................................... 8

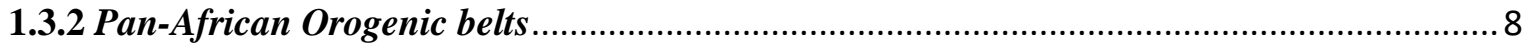

1.3.3 North Patagonian and Deseado Massifs ...................................................................... 8

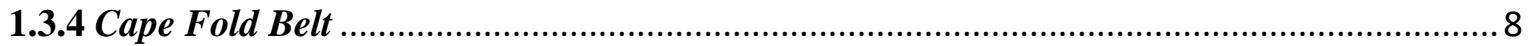

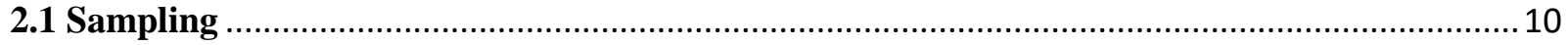

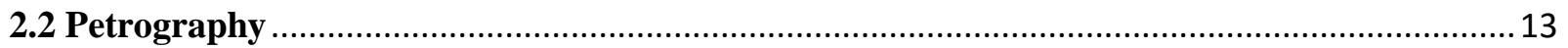

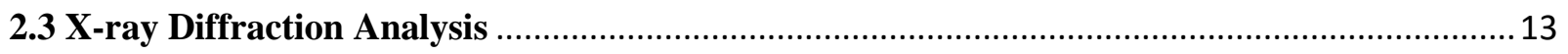

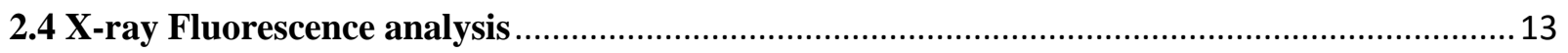

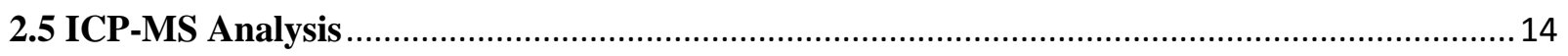

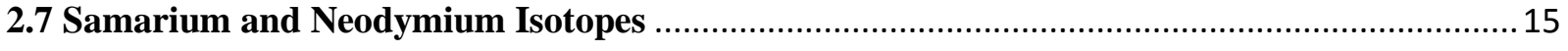

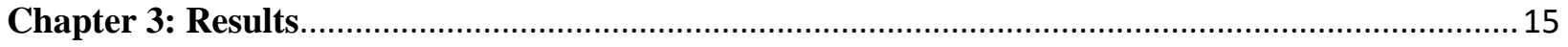

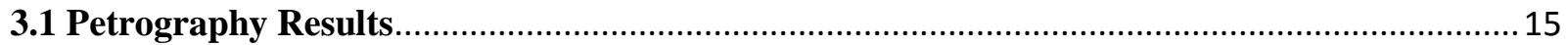

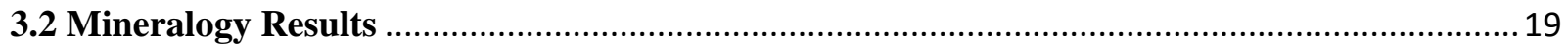

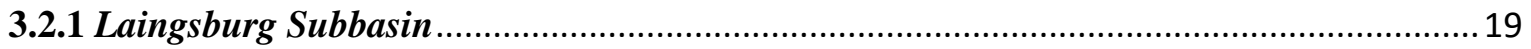

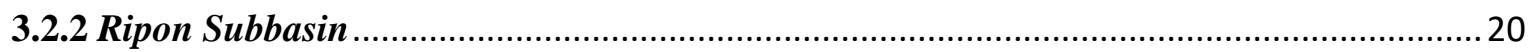

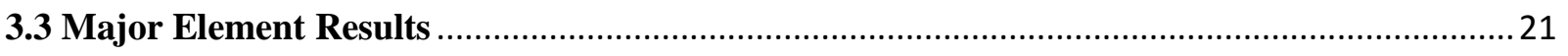

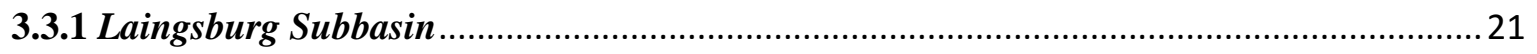




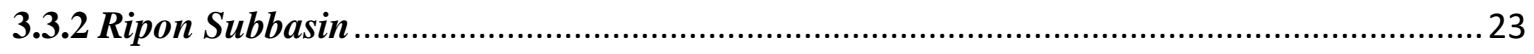

3.3.3 Comparison of Major Element Composition ..................................................................2 25

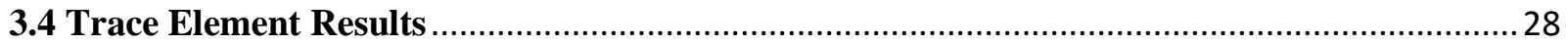

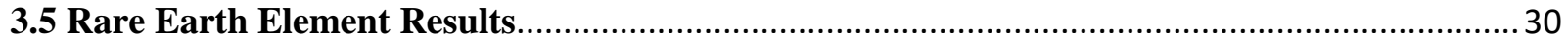

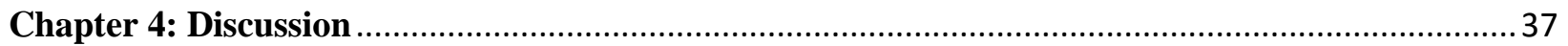

4.1 Provenance of mudstone units in the Ecca and Beaufort groups ..........................................37

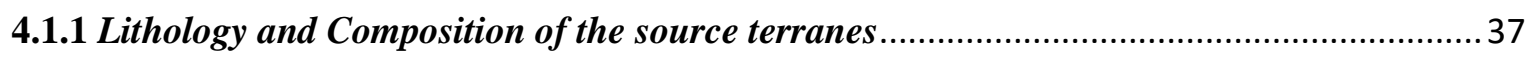

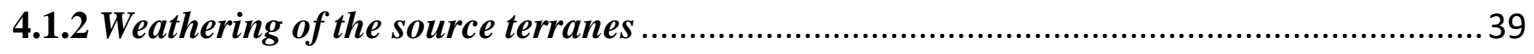

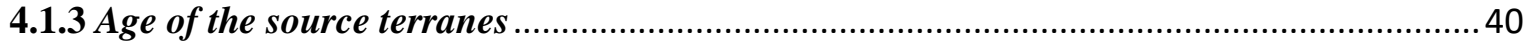

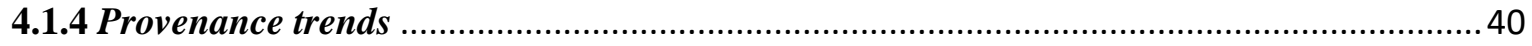

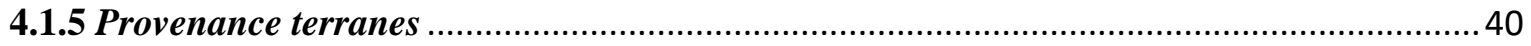

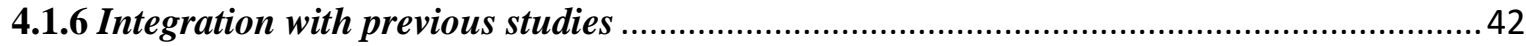

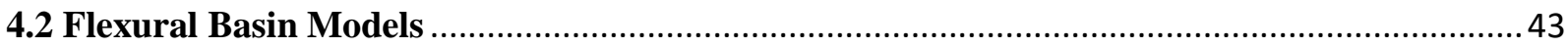

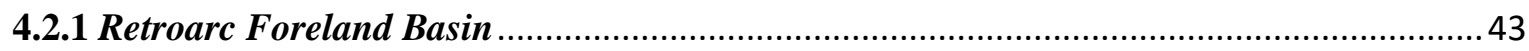

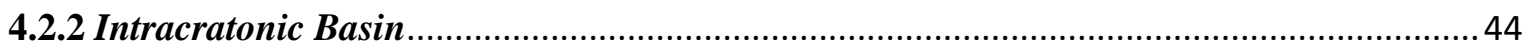

4.3 Influence of the Gondwanide Magmatic Arc and Cape Fold Belt.......................................44

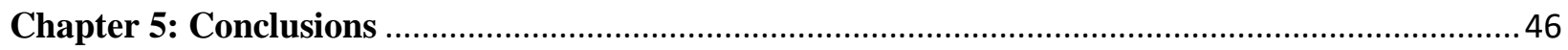

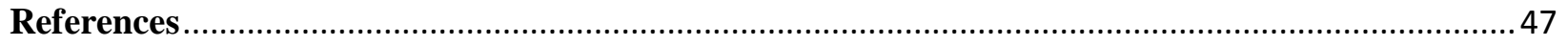

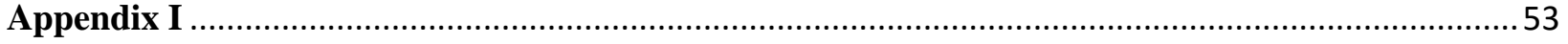

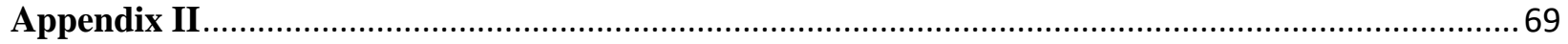

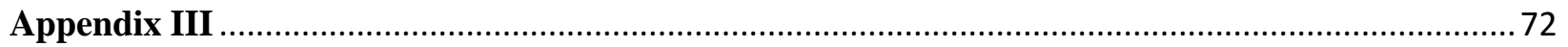

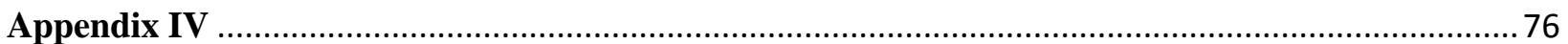




\section{List of Figures}

Figure 1: Proposed subsidence models for the Karoo Basin. A) Subduction along the southern margin of Gondwana caused the Gondwanide Magmatic Arc and Cape Fold Belt to form, resulting in crustal loading and flexural subsidence of the Karoo Basin (From Vorster, 2013). B) A mantle convection cell created by the subduction zone on the southern margin of Gondwana caused the Karoo Basin to subside by flexure and lithospheric scale faulting of the continental crust (Tankard et al., 2009; Mckay, personal communication).

Figure 2: A) Paleogeographic map of Gondwana showing Gondwanide Magmatic Arc as igneous provinces, fold-thrust belts, and Foreland Basins. B) Geologic map of the Karoo Basin (From McKay et al.,

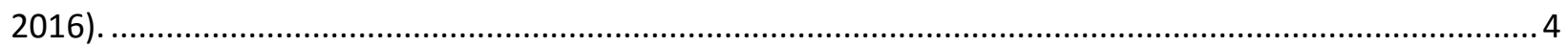

Figure 3: Generalized age-stratigraphic column of the Karoo Supergroup (From Flint et al., 2011).......... 5 Figure 4: Paleogeographic map of the Permian southern boundary of Gondwana (Modified from Pankhurst et al., 2006; Kleiman and Japas, 2009; Rapela et al., 2011; Uriz et al., 2011; Veevers and Saeed 2013; Vorster 2013, and Dean, 2014).

Figure 5: Stratigraphic columns of the Laingsburg and Ripon subbasins with sample locations (Modified after McKay, 2015; Dean, 2014; McKay et al., 2015; McKay et al., 2016).

Figure 6: Sample 14ZA144A (Whitehill Fm., Ripon subbasin) with clay and authigenic microcrystalline quartz/chert. The two images are from different locations on the thin section. Image A) 40x magnification, transmitted light, cross-polarized light; an elongate mica grain, black/brown clay, and microcrystalline quartz can be seen. B) 20x magnification, reflected light; the surface is smooth, no grains are observed with reflected light.

Figure 7: Sample 14ZA105A (Laingsburg Fm., Laingsburg subbasin) with detrital quartz silt, authigenic quartz, and mica silt grains. Image is at 40x magnification using transmitted light and cross-polarized light.

Figure 8: Sample 14ZA107 (Whitehill Fm., Laingsburg subbasin) with a detrital polycrystalline quartz sand grain, authigenic quartz, and mica silt grains. Image is at 40x magnification using transmitted light and cross-polarized light.

Figure 9: Sample 14ZA119 (Laingsburg Fm., Laingsburg subbasin) with detrital quartz sand grain that has mineral inclusions and vacuoles. Image is at 20x magnification using cross-polarized light. ...................18 Figure 10: Mineralogy of samples from the Laingsburg subbasin in stratigraphic order........................20 Figure 11: Mineralogy of samples from the Ripon subbasin in stratigraphic order...............................21 Figure 12: Plots of major elements from samples of the Laingsburg Subbasin (Blue) and NASC averages (Orange; data from Gromet et al., 1984).

Figure 13: CIA and ICV values of the Laingsburg subbasin samples. CIA values decrease upsection. ICV values increase upsection.

Figure 14: Plots of major elements from samples of the Ripon Subbasin (Blue) and NASC averages (Orange; data from Gromet et al., 1984).....

Figure 15: CIA and ICV values of the Ripon subbasin samples. CIA decreases upsection, and ICV increases upsection. .25

Figure 16: Plots of CIA and ICV against various mineral weight percentage in all samples from both subbasins show a correlation between $\mathrm{CIA}$ and albite weight percentage $\left(R^{2}=0.63\right)$ and a weak 
correlation between ICV and quartz weight percentage $\left(R^{2}=0.19\right)$, but not between any other weathering index with mineral weight percentage.

Figure 17: The A-CN-K diagram; weathering trends for basalt, andesite, average upper Archean upper crust, granodiorite, adamellite, and granite are shown, as well as the small square representing average Paleoproterozoic cratonic shale, and small dots representing the samples of this study (Modified after Nesbitt and Young, 1989; McLennan et al., 1990; Fedo et al., 1995)...

Figure 18: A plot of CIA versus potassium shows no correlation. Data from both subbasins (blue) and NASC (orange) values are plotted. A plot of $\mathrm{K}_{2} \mathrm{O}$ versus muscovite weight percentage shows a correlation between high muscovite content and high $\mathrm{K}_{2} \mathrm{O}$ content.

Figure 19: $\mathrm{TiO}_{2} / \mathrm{Al}_{2} \mathrm{O}_{3}$ is an indicator of source rock composition. Higher values upsection indicate more mafic sediment upsection, especially in the Ripon Subbasin.

Figure 20: Multi-element diagrams of trace elements from the Ripon (A) and Laingsburg (B) subbasins showing an active continental margin arc signature (Pearce, 1983).

Figure 21: Cross-plots of Th/U versus Th show that samples have a wide range of $T h / U$ ratio values that increase upsection. A Th/U value greater than 4 indicates a crustal source that has undergone weathering (Modified after McLennan et al., 1993).

Figure 22: Crossplots of Th/Sc versus $\mathrm{Zr} / \mathrm{Sc}$ showing $\mathrm{Zr}$ and Th enrichment in samples of both subbasins (Modified after McLennan et al., 1993). .30

Figure 23: A crossplot of $\mathrm{CIA}$ versus Th/U shows nor correlation and indicates major elements do not change at the same rate as $U$ during weathering.

Figure 24: REE profiles from the Ripon subbasin. All samples have LREE enrichment, negative Eu anomaly, and HREE depletion. Samples 14ZA149, 14ZA150, 14ZA151, 14ZA152, 14ZA153, 14ZA155, and 14ZA156 from the Ripon Fm., 14ZA165 from the Waterford Fm., and 14ZA162 and 14ZA160 from the Balfour Fm. have a negative Ce anomaly......

Figure 25: REE profiles from the Laingsburg subbasin. All samples have LREE enrichment, negative Eu anomaly, and HREE depletion. 14ZA98A from the Laingsburg Fm., 14ZA122 from the base of the Waterford Fm., and 14ZA130C from the Abrahamskral Fm. have a negative Ce anomaly.

Figure 26: In the Ripon subbasin, $\Sigma R E E$ versus $C I A$ and ICV show weak $\left(R^{2}=0.31\right)$ and no correlation ( $0.02)$, respectively.

Figure 27: $\Sigma R E E$ versus CIA and ICV show weak $\left(R^{2}=0.13\right)$ and no correlation $\left(R^{2}=0.00\right)$, respectively in the Laingsburg subbasin.

Figure 28: In the Ripon subbasin, $\sum$ REE versus albite and quartz weight $\%$ show no correlation $\left(R^{2}=0.00\right.$ and 0.00 , respectively).

Figure 29: In the Ripon subbasin, $\Sigma$ REE versus albite and quartz weight $\%$ show weak correlations ( $R^{2}=0.11$ and 0.15 , respectively).

Figure 30: $\varepsilon N d$ becomes more negative upsection. Data from the lowermost and middle formations of the Ecca Group in the Laingsburg subbasin.

Figure 31: TCHUR increases upsection in the same samples as in the above $\varepsilon N d$ plot ...........................36 Figure 32: Sm-Nd data versus $\Sigma R E E$, albite, and CIA. A crossplot of $\Sigma R E E$ versus $\varepsilon N d$ shows a correlation between high $\Sigma R E E$ and a more negative $\varepsilon N d$ value. A crossplot of albite weight percentage versus $\varepsilon N d$ shows no correlation. A crossplot of albite versus $\mathrm{T}_{\text {CHUR }}$ shows a weak correlation between high albite content and older model age. Crossplots of CIA versus $\varepsilon N d$ and $T_{C H U R}$ show the opposite trend, because high albite content corresponds with low CIA. 
Figure 33: REE profile of volcanic tuffs from the Ecca (blue) and Beaufort (green) groups of the Karoo Basin, and the Choiyoi (upper=gold, lower=red) and Puesto Viejo (yellow) groups of the Gondwanide Magmatic Arc (McKay et al., 2016).....

Figure 34: Map of terranes of Permian-Triassic southern Gondwana with provenance arrows interpreted in this study (Modified from Pankhurst et al., 2006; Kleiman and Japas, 2009; Rapela et al., 2011; Uriz et al., 2011; Veevers and Saeed 2013; Vorster 2013, and Dean, 2014).

Figure 35: Drainage network types. A) Multiple minor rivers cross the emerging fold belt and empties sediment into the basin as a line source. B) A major river cuts across the uplifted fold belt and empties sediment into the basin as a point source (Taken from Busby and Ingersol, 1995).....

\section{List of Tables}

Table 1: Sample locations with formation name, color description, and analysis performed..................11

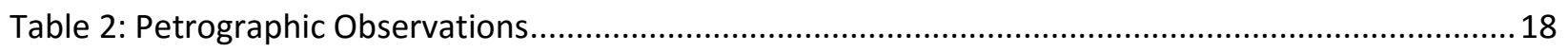

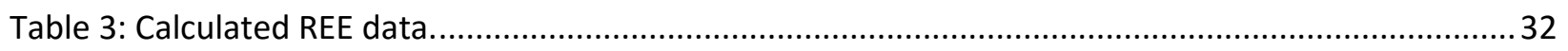




\section{Chapter 1: Introduction}

\subsection{Research Problem}

Controversy has surrounded the tectonic setting and subsidence mechanism of the Karoo Basin in South Africa (Cole, 1992; Catuneanu et al., 1998; Catuneanu et al., 2002; Tankard et al., 2009). Results from prior work have been used to interpret Karoo Basin as a retroarc foreland basin, in which subsidence resulted from flexure driven by crustal loading by the Cape Fold Belt and Gondwanide Magmatic Arc (Figure 1A; Cole, 1992; Catuneanu et al., 1998; Catuneanu et al., 2002). Alternate models have presented the Karoo Basin as an intracratonic basin produced by flexural subsidence from mantle convection cell flow, driven mainly by subduction of the paleo-Pacific plate, without additional loading by the Cape Fold Belt (Figure 1B; Tankard et al., 2009). Basin history has implications for interpreting controls on sediment dispersal and sedimentation rate. In foreland basins, sedimentation rate can be high, particularly in areas proximal to the thrust-belt, due to high relief in the source area, sedimentation is concentrated near the orogenic belt, and deformation in the orogenic belt can control sediment dispersal (Busby and Ingersol, 1995). In intracratonic basins, sedimentation rate is low due to low relief in the source area and carbonates are often deposited due to low sediment supply (Busby and Ingersol, 1995).

This work aims to address the controversy over tectonic evolution of the Karoo Basin clastic fill by investigating provenance of mudstone units in the Ecca and Beaufort groups. The Permian and Triassic Ecca and Beaufort groups in the Karoo Basin of South Africa preserve a thick, well-exposed succession of clastic basin fill, including several mud-dominated intervals in the lower Ecca Group, mud-rich turbidite sequences within the upper Ecca Group and deltaic and fluvial deposits of the Beaufort Group that are all thought to have been derived from southern sources (Johnson, 1991; Vorster, 2014; Dean, 2014), and less well studied hemipelagic mudstone units of the lower Ecca Group for which provenance is unknown. The Ecca Group overlies the older glaciogenic Dwyka Group that was derived from terranes to the north (Johnson, 1991; Vorster, 2014). Geochemical evaluation of source rock lithology and age permits temporal constraints on the switch from northern to southern sediment source areas. Provenance of magmatic arc and fold-belt sources to the south support formation as a retroarc flexural foreland basin with subsidence driven by crustal loading from the Gondwanide Magmatic Arc and/or the Cape Fold Belt. In contrast, limited or lack of input from the Gondwanide Magmatic Arc and Cape Fold Belt sources supports the intracratonic basin model, in which regional flexural basin subsidence was driven by mantle flow processes. To constrain provenance of Ecca and Beaufort Group sediment, and sedimentation, this project investigates the texture, mineralogy, major element, trace element, rare earth element, and Sm-Nd isotope data from mudstones of the Karoo Supergroup. These results are integrated with previously published sandstone $\mathrm{U}-\mathrm{Pb}$ detrital zircon age, paleoflow, sandstone petrography, Sm-Nd sandstone age, mudstone geochemical, volcanic ash U-Pb zircon age, and volcanic tuff geochemical data in order to explore the relationship between the Gondwanide Magmatic Arc, deformation in the Cape Fold Belt, and the mechanism subsidence in the Karoo Basin. 


\section{Passive Margin}

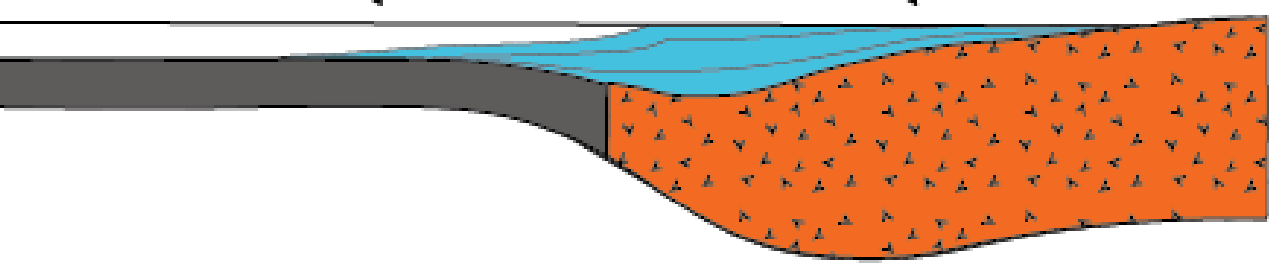

b. Late Permian

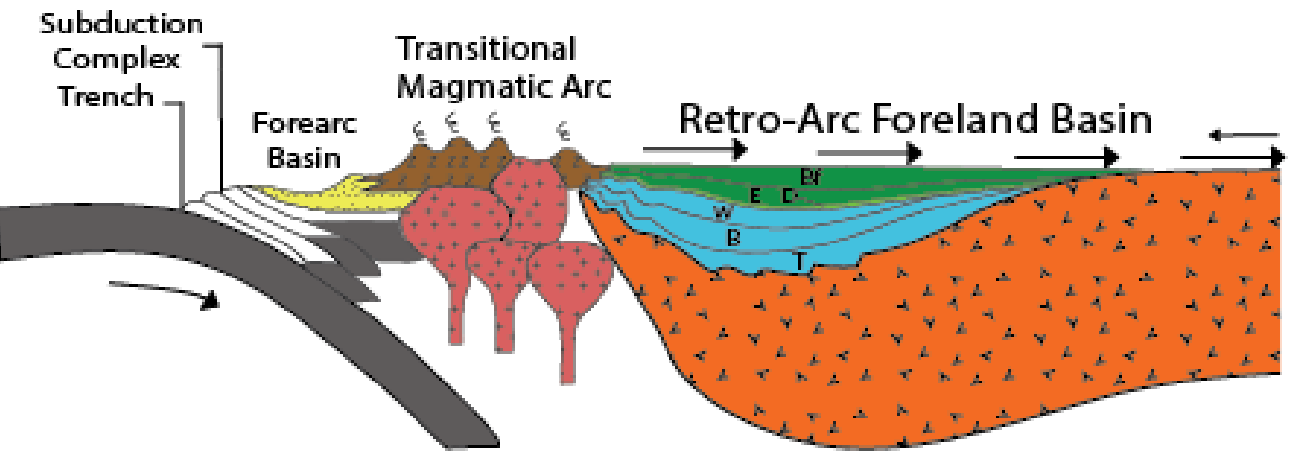

c. Late Triassic
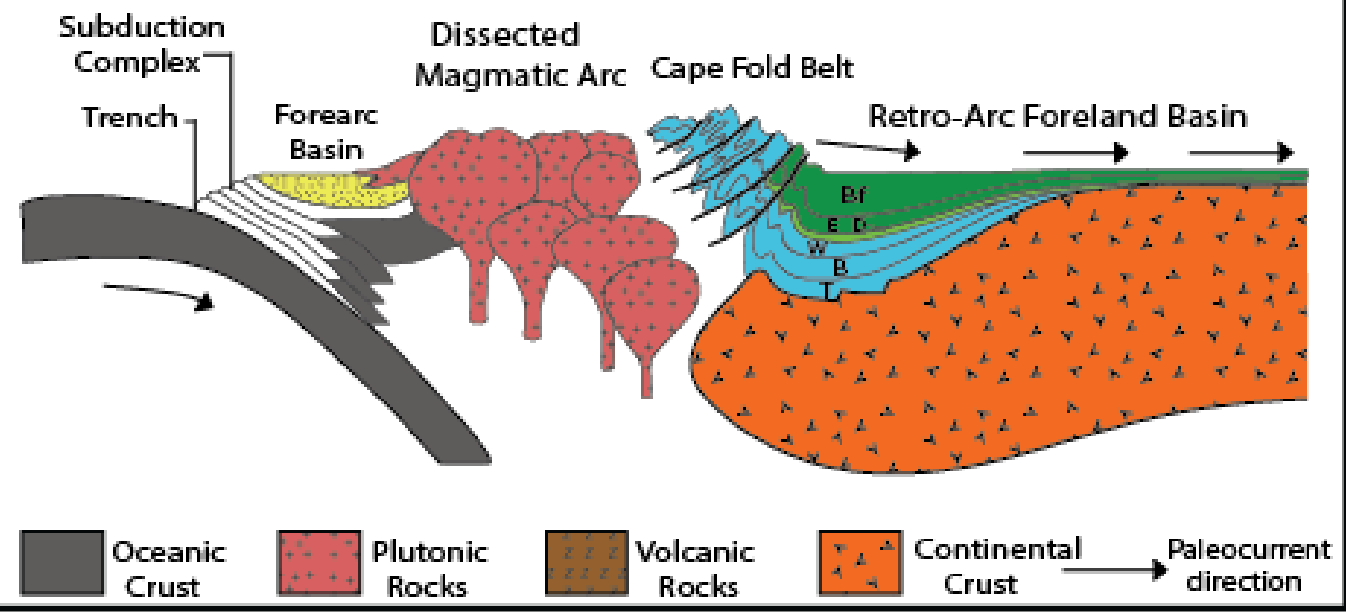

Figure 1: Proposed subsidence models for the Karoo Basin. A) Subduction along the southern margin of Gondwana caused the Gondwanide Magmatic Arc and Cape Fold Belt to form, resulting in crustal loading and flexural subsidence of the Karoo Basin (From Vorster, 2013). B) A mantle convection cell created by the subduction zone on the southern margin of Gondwana caused the Karoo Basin to subside by flexure and lithospheric scale faulting of the continental crust (Tankard et al., 2009; Mckay, personal communication). 

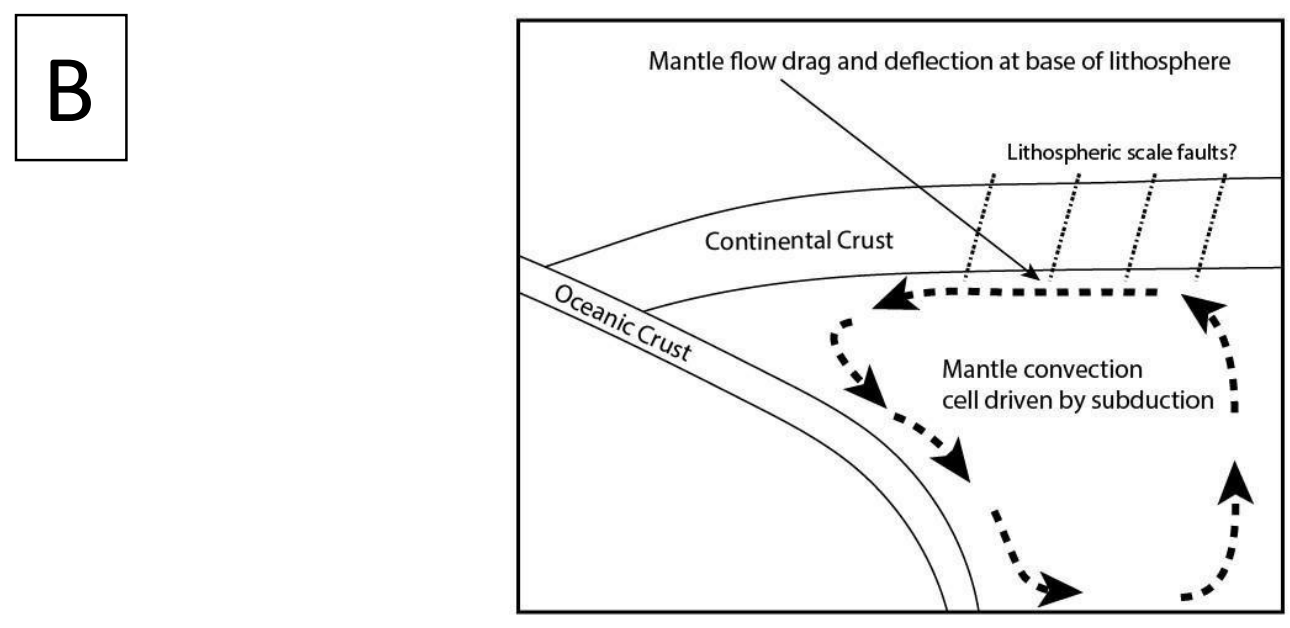

\subsection{Geologic Background}

\subsubsection{Tectonic setting}

Several periods of extension and compression shaped southern Gondwana over a period of about 600 million years, starting in the Late Precambrian (De Wit and Ransome, 1992). Late Proterozoic to early Paleozoic extension formed the Atlantic-style passive margin Cape Basin, in which the Cape Supergroup was deposited (Bouma and Wickens, 1994; Wickens and Bouma, 2000). During late Paleozoic time, the southern margin of Gondwana transformed into an Andean-style foreland basin (Cole, 1992; Catuneanu et al., 1998) or intracratonic basin (Catuneanu et al., 2002; Tankard et al., 2009) to form the Karoo Basin. Development of the Karoo basin occurred synchronously with late Paleozoic subduction of the paleo-Pacific Plate beneath the Panthalassan margin of Gondwana. The Gondwanide Magmatic Arc, a series of foldthrust belts including the Cape Fold Belt, and a sedimentary basin system, including the Karoo Basin, formed in association to this subduction zone (Figure 2; Johnson, 1991; Cole, 1992; Bouma and Wickens, 1994; Shone and Booth, 2005). The Cape Fold Belt, which bounds the southern Karoo Basin to the west and south, formed from deformation of Paleozoic metasedimentary and sedimentary rocks during the Permian-Triassic Cape Orogeny (Halbich et al., 1983; Gresse et al., 1992; McKay, 2015). Later Mesozoic rifting of Gondwana resulted in the formation of a passive margin along southern Africa, and remnants of the Gonwanide convergent margin system were preserved in South America, Africa, the Falkland Islands, Antarctica, and Australia (Lopez-Gamundi, 2006). 


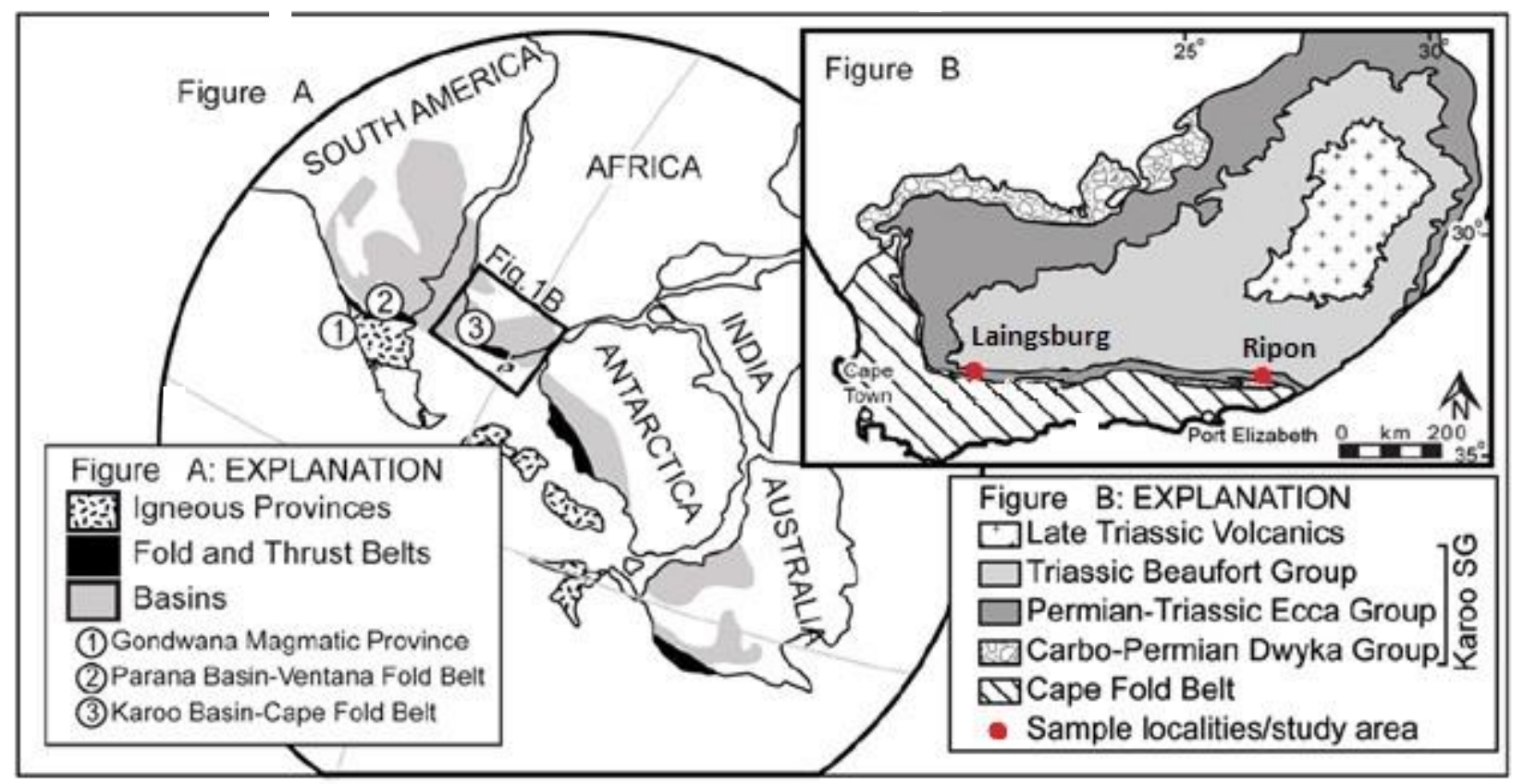

Figure 2: A) Paleogeographic map of Gondwana showing Gondwanide Magmatic Arc as igneous provinces, fold-thrust belts, and Foreland Basins. B) Geologic map of the Karoo Basin (From McKay et al., 2016).

\subsubsection{Karoo Basin Stratigraphy}

The Carboniferous to Jurassic Karoo Supergroup preserves clastic fill of the Karoo Basin. At the base of the Karoo Supergroup, the Carboniferous to Permian Dwyka Group is interpreted to be glacial diamictite approximately 160-800 meters thick and consisting of clasts of varying lithology suspended in a fine-grained matrix (Johnson, 1994; Cole, 1992; Blignault and Theron, 2012) was deposited as continental ice sheets to the north receded and melted, causing a marine transgression (Cole, 1992; Johnson, 1997). Overlying the Dwyka Group are the argillaceous marine deposits of the Permian-Triassic Ecca Group and fluvial sandstone deposits of the Triassic Beaufort Group (Fildani et al., 2009). The marine to marginal marine Ecca Group strata are divided across the southern Karoo basin into three subbasins: the Tanqua subbasin in the west/southwest, the Laingsburg subbasin in the southwest, and the Ripon subbasin in the southeast (Figure 2). The lowermost formations of the Ecca Group (Prince Albert, Whitehill, and Collingham formations) are mudstone dominated and were deposited in a deep marine environment (Johnson et al., 1997; Wickens and Bouma, 2000; Fildani et al., 2009). The basal unit of the Ecca Group is the Permian Prince Albert Formation, which is dominated by shale deposited in a sediment starved marine environment (Figure 3) (Johnson et al., 1997; Wickens and Bouma, 2000; Fildani et al., 2009). Overlying the Prince Albert Formation, the Permian Whitehill Formation is composed of black, carbonaceous shale deposited in a clastic sedimentstarved, anoxic marine environment (Johnson et al, 1997; Wickens and Bouma, 2000). Above the Whitehill Formation is the Permian Collingham Formation, which represents a transition from a sediment-starved basin to deposition of dilute, mud-rich turbidites and abundant thin volcanic air fall ash beds (Johnson et al., 1997; Wickens and Bouma, 2000). The Whitehill and Collingham formations thin over the Ceres Syntaxis, a structural high that formed during the 
Cape Orogeny, suggesting Late Permian syndeformational deposition (Wickens, 1994; Scott et al., 2000). Each of the sub-basins has a different stratigraphic sequence above the Collingham Formation, but each includes facies that represent the progradation of submarine fans and eventually shelfal, deltaic, and fluvial deposits into the sub-basins (Johnson, 1991; Cole, 1992; Catuneanu, 1998; Wickens and Bouma, 2000). Finally, conformably overlying the Ecca Group is the Triassic Beaufort Group that represents the transition from marginal marine environments to fluvial, terrestrial depositional environments in the basin. Beaufort Group strata consist of overbank mudstone and siltstones interbedded with sandstone deposited by fluvial systems (Catuneanu et al., 1998; Wilson et al., 2014). Paleoflow measurements in the northern, distal regions of the Karoo basin in the lowermost formations of the Ecca Group indicate sediment may be derived from the north and east (Ryan and Whitfield, 1979), but paleoflow measurements (Ryan and Whitfield, 1979; Johnson, 1991; Cole, 1992; Veevers, 1994; Wickens, 1996; Wickens and Bouma, 2000), geochemistry (Andersson 2003, 2004, 2006), and dating of detrital zircon with U-Pb isotopes (Vorster, 2014; Dean, 2014) indicate sandstone of the Ecca and Beaufort groups in the southern, proximal regions of the basin was derived from the south. Mud, however, is often transported further than sand and could be sourced from one dominant sediment influx or reflect a mixture of clay influx from source terranes surrounding the basin, depending on the basin margin paleogeography and the configuration of associated drainage systems.

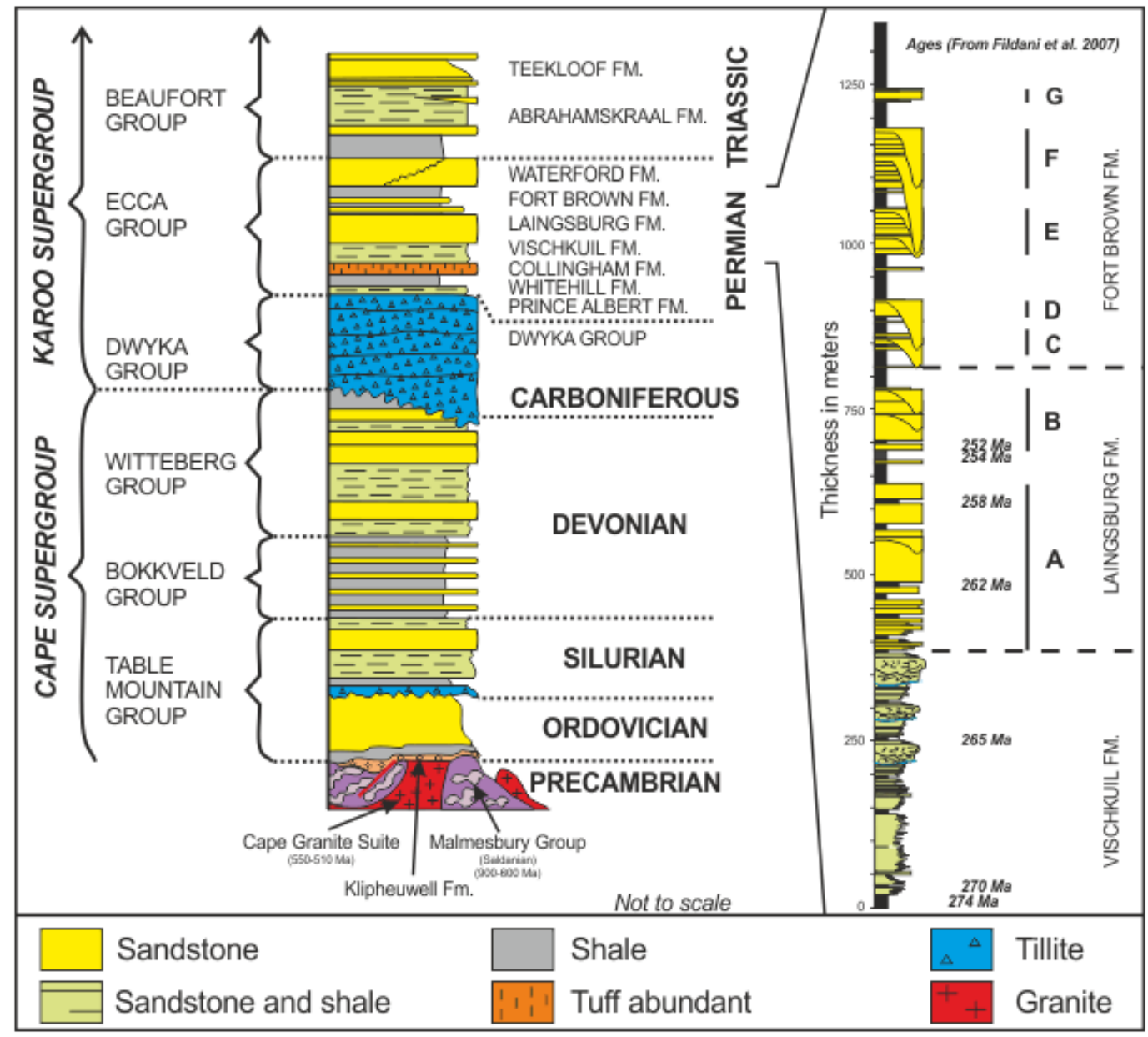

Figure 3: Generalized age-stratigraphic column of the Karoo Supergroup (From Flint et al., 2011). 


\subsubsection{Laingsburg Subbasin}

In the Laingsburg subbasin, the Permian Vischkuil Formation overlies the Collingham Formation and contains thinly-laminated to massive dark shales up to $15 \mathrm{~m}$ thick interbedded with mud-rich, fine-grained turbidites up to $1.5 \mathrm{~m}$ thick (Johnson et al., 1997). Up-section, the Permian - Triassic Laingsburg Formation includes four submarine fan units, A through D, each up to $30 \mathrm{~m}$ thick and composed of medium- to fine-grained mid-fan channel fill to outer-fan lobe deposits, and interbedded hemipelagic, siliciclastic mudstone (Wickens, 1994; Johnson et al., 1997; Scott et al., 2000). Overlying the Laingsburg Formation are the Fort Brown and Waterford formations, which record the transition from deep-marine to shelf and deltaic deposits (Johnson et al., 1996; Flint et al., 2011).

\subsubsection{Ripon Subbasin}

In the Ripon sub-basin of the eastern Karoo basin, the Permian-Triassic Ripon Formation overlies the Collingham Formation, and is characterized by submarine fan deposits up to $44 \mathrm{~m}$ and averaging $12 \mathrm{~m}$ of very fine- to medium-grained lithofeldspathic sandstone separated by thick, hemipelagic mudstone units (Johnson et al., 1997). Sandstone units of the Ripon Formation contain fine- to medium-grained sand and are coarser than the Laingsburg Formation, but are separated by thicker hemipelagic mudstone deposits (Veevers et al., 1994). Overlying the Ripon Formation are the Fort Brown and Waterford formations that represent the same transition to shelf and deltaic deposits as in the Laingsburg sub-basin.

\subsubsection{Previous Provenance Studies}

Previous studies that have interpreted depositional environments, basin fill patterns, and provenance of sandstone of the Ecca and Beaufort groups have associated Karoo basin clastics with three sources areas for the Ecca Group have been proposed based on sandstone framework grain mineralogy and paleocurrent data: a volcanically active magmatic arc (Gondwanide Magmatic Arc to the south), a metasedimentary orogenic belt (Cape Fold Belt to the south), and a granitic/gneissic basement (Kalahari Craton and Namaqua-Natal Metamorphic Province to the north), though the magmatic arc source is thought to have contributed the most sediment to the Ecca Group and overlying formations (Johnson, 1991; Vorster, 2013). Petrographic studies of sandstone in the basin show QFL and QmFLt ratios differ substantially between Cape Supergroup and Dwyka Group sandstone to Ecca Group sandstone (Johnson, 1991). The Dwyka Group sandstone plots with the Cape Supergroup sandstone in the non-orogenic continental block provenance region of the QmFLt plot, while the Ecca and Beaufort Group sandstone plot in regions of magmatic arc provenance (Johnson, 1991). This transition represents a change in sediment transport direction from South to North, but a large gap in provenance remains in the Ecca Group stratigraphy where no sandstone was deposited. Paleoflow direction in the northern, distal part of the basin has been measured from sedimentary structures as south and west in the lowermost formations of the Ecca Group (Ryan and Whitfield, 1979). However, in the southern proximal part of the basin on which this study focuses, the Tanqua, Laingsburg, and Ripon formations of the Ecca Group prograded northeast with a paleocurrent varying from north to east (Ryan and Whitfield, 1979; Johnson, 1991; Cole, 1992; Veevers, 1994; Wickens, 1996; Wickens and Bouma, 2000).

Geochemical investigations of Karoo Basin provenance are more limited. Sm-Nd isotopes, rare earth elements, and major and minor elements of Guadalupian-Early Triassic (Fildani et al., 2007, 2009; McKay et al., 2016) Skoorsteensburg Formation sandstone and 
mudstone in the Tanqua depocenter (south western Karoo Basin) were analyzed in order to determine sedimentary provenance and paleoclimate (Andersson, 2003, 2004, 2006). Nd-model ages from sandstone samples, calculated relative to the chondritic uniform reservoir, show ages of Neoproterozoic. Along with paleoflow indicators, this indicates provenance is the Cape Fold Belt and Gondwanide Magmatic Arc to the south (Andersson, 2003). Rare earth elements are uniform through the Skoorsteensburg Formation indicating a constant provenance, but major and trace element plots indicate a greater contribution of felsic and mafic material through time as well as an increase in feldspar content and decrease in CIA values (Andersson, 2006). These trends indicate an evolving source, possibly the transition from a felsic undissected arc to the exposure of the mafic core of the same magmatic arc, but over time the climate became more arid so that feldspar was not weathered to clays as quickly (Andersson, 2006). However, this study was limited to a thin interval of $\sim 400$ meters out of the $\sim 1700-2100$ meters of the Ecca Group and require greater context in order to assess provenance significance.

Recently, detrital zircons from the Cape Supergroup, Dwyka, Laingsburg, and Ripon formations were dated using the U-Pb isotope system in order to determine provenance (Vorster, 2013; Dean, 2014). The Laingsburg and Ripon formations contain zircon populations with a major juvenile population of $\sim 245 \mathrm{Ma}-295 \mathrm{Ma}$, a secondary population of age $350 \mathrm{Ma}-750$ Ma, and several minor age populations (Vorster, 2013; Dean, 2014). The amount of zircon grains from older population increase upsection (Dean, 2014). In contrast, Cape Supergroup and Dwyka Group rocks contain zircons of age $400 \mathrm{Ma}-3500 \mathrm{Ma}$ (Vorster, 2014). These data indicate that a source of Permian zircon began contributing sediment to the basin sometime between deposition of the Dwyka Group and deposition of the Laingsburg and Ripon formations. Detrital zircon studies of the Ecca and Beaufort groups show greater amounts of Ordovician, Neoproterozoic, and Mesoproterozoic age zircon upsection and less Permian age zircon upsection (Dean, 2014). Integrating this data with northward directed paleocurrent indicators in the region of the basin proximal to the Cape Fold Belt, the Permian - Triassic Gondwanide Magmatic Arc is interpreted to be a major source of the Ecca Group sandstone zircon, and Devonian - Neoproterozoic zircon are interpreted to be derived from reworking of Cape Supergroup and Dwyka Group rocks exposed in the Cape Fold belt (Vorster, 2013). These studies interpreted the Karoo Basin as a retroarc foreland basin because of the contribution of sediment from the arc and fold belt.

Past studies of Ecca Group sandstone and mudstone interpret the source of the Ecca Group as the Gondwanide Magmatic Arc and the Cape Fold Belt. However, studies have not been done in the stratigraphy below the Laingsburg Formation, and the only study on mudstone was done on a single formation in the Tanqua subbasin. This study aims to constrain provenance of older Karoo Basin fill than has been previously studied, and support sandstone provenance studies of the Ecca and Beaufort groups through alternative methods.

\subsection{Provenance Terranes}

Provenance of sediment influx into a basin is an important constraint for understanding the tectonic processes influencing regional basin development and distribution of sediment in a basin. Five main potential sources with distinct geochemical and geochronological signatures exist for Karoo Basin clastics: 1) Kalahari Craton and Namaqua-Natal Metamorphic Province, 2) Pan-African Orogenic belts, 3) North Patagonian and Deseado Massifs, 4) Cape Fold Belt, and 
5) Gondwanide Magmatic Arc. These source areas are characterized in terms of their geological evolution, age and lithology below.

\subsubsection{Kalahari Craton and Namaqua-Natal Metamorphic Province}

The Precambrian Kalahari Craton and Namaqua-Natal Metamorphic Province are continental terranes to the north of the Karoo Basin, and consist of metamorphic and granitic rocks (Figure 4) (Vorster, 2013). The Archean Kalahari Craton (>2.5 Ga) consists of granitic and metamorphic rocks that have been a stable craton for $2.3 \mathrm{Ga}$ (Priestley et al., 2006). The Namaqua-Natal Metamorphic Province consists of $\sim 2$ Ga metamorphic rocks, $\sim 1.2-\sim 1.6 \mathrm{Ga}$ volcanic rocks emplaced during the Namaquan Wilson Cycle, and $\sim 1.2-1.0 \mathrm{Ga}$ granitic intrusions emplaced during the Kibaran and Namaquan Orogeny (Cornell et al., 2006; Bailie et al., 2007).

\subsubsection{Pan-African Orogenic belts}

The Gariep and Saldania belts to the northwest and southwest, respectively, of the Karoo Basin deformed rocks of the Kaapvaal Craton and Namaqua-Natal Metamorphic Province during the Neoproterozoic-Cambrian Pan-African Orogeny (Figure 4) (Gresse et al., 2006; Vorster, 2013). In addition to these Precambrian rocks, the Gariep Belt contains Neoproterozoic (771 $837 \mathrm{Ma}$ ) felsic igneous rocks and Cambrian (507-529 Ma) granitic intrusions, and the Saldania Belt contains Neoproterozoic-Cambrian (575-515 Ma) granitic intrusions (Gresse and Scheepers, 1993; Gresse et al., 2006; Vorster, 2013). The Saldania Belt was largely covered by the Cape Supergroup in the Ordovician-Devonian (Chemale et al., 2011).

\subsubsection{North Patagonian and Deseado Massifs}

The North Patagonian Massif and the Deseado Massifs are situated on the southern margin of Gondwana in paleogeographic maps (Figure 4) (Pankurst et al., 2006; Vorster, 2013). Cambrian-Ordovician metasedimentary rocks of the North Patagonian Terrane have a Gondwanan affinity and are intruded by Ordovician, Carboniferous, and most heavily by early Permian granites, suggesting this terrane was a part of Gondwana from Cambrian to Permian times (Pankurst et al., 2006). The Deseado Massif is thought to have collided with the southern margin of the North Patagonian Massif during Carboniferous times, and is heavily intruded by early Permian granites (Pankurst et al., 2006). The Permian granites of these terranes are part of the Gondwanide Magmatic Arc.

\subsubsection{Cape Fold Belt}

The Cape Supergroup and Dwyka Group underlie the Karoo Supergroup, and were deposited on an early Paleozoic passive margin (Figures 2 and 3) (Veevers et al., 1994, Vorster, 2013). The Cape Supergroup was deposited in the Ordovician-Devonian Cape Basin, bounded to the north by the Namaqua-Natal Metamorphic Province and extending out from the southern margin of Gondwana (Veevers et al., 1994; Thamm and Johnson, 2006). It is split into three groups: the Table Mountain, Bokkeveld, and Witteberg groups (Veevers et al., 1994). The Ordovician-Early Devonian Table Mountain Group is a 3,500 meter thick succession of alluvial, fluvial and shallow marine conglomerate, sandstone, and mudstone that was metamorphosed into quartzite and phyllite (Veevers et al., 1994; Johnson, 1994; Vorster, 2013). The Early-Mid Devonian Bokkeveld Group is a 2200-3500 meter thick succession of argillaceous sandstone and mudstone that was metamorphosed into quartzite and phyllite (Thamm and Johnson, 2006; Vorster, 2013). The Mid-Devonian-Middle Mississippian Witteberg Group consists of 12001700 meters of mudstone, siltstone, and sandstone that were metamorphosed into quartzite and 
phyllite (Thamm and Johnson, 2006; Vorster, 2013). The sedimentary and metasedimentary rocks of the Cape Supergroup contain detrital zircons aged between 350 - 3500 Ma, with dominant ages of 400 - $700 \mathrm{Ma}$ and 900 - $1300 \mathrm{Ma}$ (Johnson, 1991; Craddock and Thomas, 2011; Vorster, 2013). They are derived from northern terranes, such as the Kalahari Craton and Namaqua-Natal Metamorphic Province (Vorster, 2013). The Late Carboniferous-early Permian Dwyka Group was deposited on top of the Ordovician-Carboniferous Cape Supergroup, and is bounded by the Namaqua-Natal Metamorphic Belt and Kalahari Craton in the north (Johnson, 1994; Vorster, 2013). The Dwyka Group is an. The Cape Supergroup and Dwyka Group were then deformed and metamorphosed by the Permian - Triassic Cape Orogeny (Halbich et al., 1983; Gresse et al., 1992).

\subsubsection{Gondwanide Magmatic Arc}

Only part of the Gondwanide Magmatic Arc is preserved and exposed at the surface today, but its paleogeographical extent is inferred by the presence of Permian-Triassic fold-thrust belts and sedimentary basins along the southern margin of Gondwana (Figure 2). Remnants of the arc are preserved as rhyolite and granite of the Choiyoi magmatic province in South America and as granite intrusions in the North Patagonian and Deseado Massifs (Figure 4) (Lopez Gamundi, 2006; Pankhurst et al., 2006; Kleiman and Japas, 2009; Rocha-Campos et al., 2011). The geochemical signature changes between the lower and upper Choiyoi rocks from low $\mathrm{Zr}$ $(<200 \mathrm{ppm}), \mathrm{Nb}(<15 \mathrm{ppm})$, and Y $(<80 \mathrm{ppm})$ and high $\mathrm{Sr} / \mathrm{Y}(>40)$ in the early to middle Permian lower Choiyoi Group to elevated Zr (100-700 ppm), Nb (10-35 ppm), and Y (70-90 $\mathrm{ppm}$ ), and low $\mathrm{Sr} / \mathrm{Y}(<40)$ in the middle to late Permian upper Choiyoi Group (Kleiman and Japas, 2009; McKay et al., 2016). Volcanic tuffs in the Ecca Group are thought to be derived from the Gondwanide arc, and geochemistry reflects the same change observed in Choiyoi Group rocks, indicating magmatism switched from subduction-driven, reflected by oxidizing magma composition, to intraplate, shallow-sourced magmatism, characterized by reducing magma chemistry during the middle Permian ( 260 Ma) (McKay, 2015; McKay et al., 2016). Choiyoi rocks are coeval with volcanic ash deposits in the Karoo Basin, indicating that Gondwanide Arc magmatism and basin subsidence were coeval (Lopez-Gamundi, 2006; Vorster, 2014). Based on the age of Choiyoi rocks in South America and ash beds in the Karoo Basin, magmatism occurred from about 276 to 234 Ma during the Permian along the Panthalassan margin of Gondwana (Lopez-Gamundi, 2006; Rocha-Campos et al., 2011). 


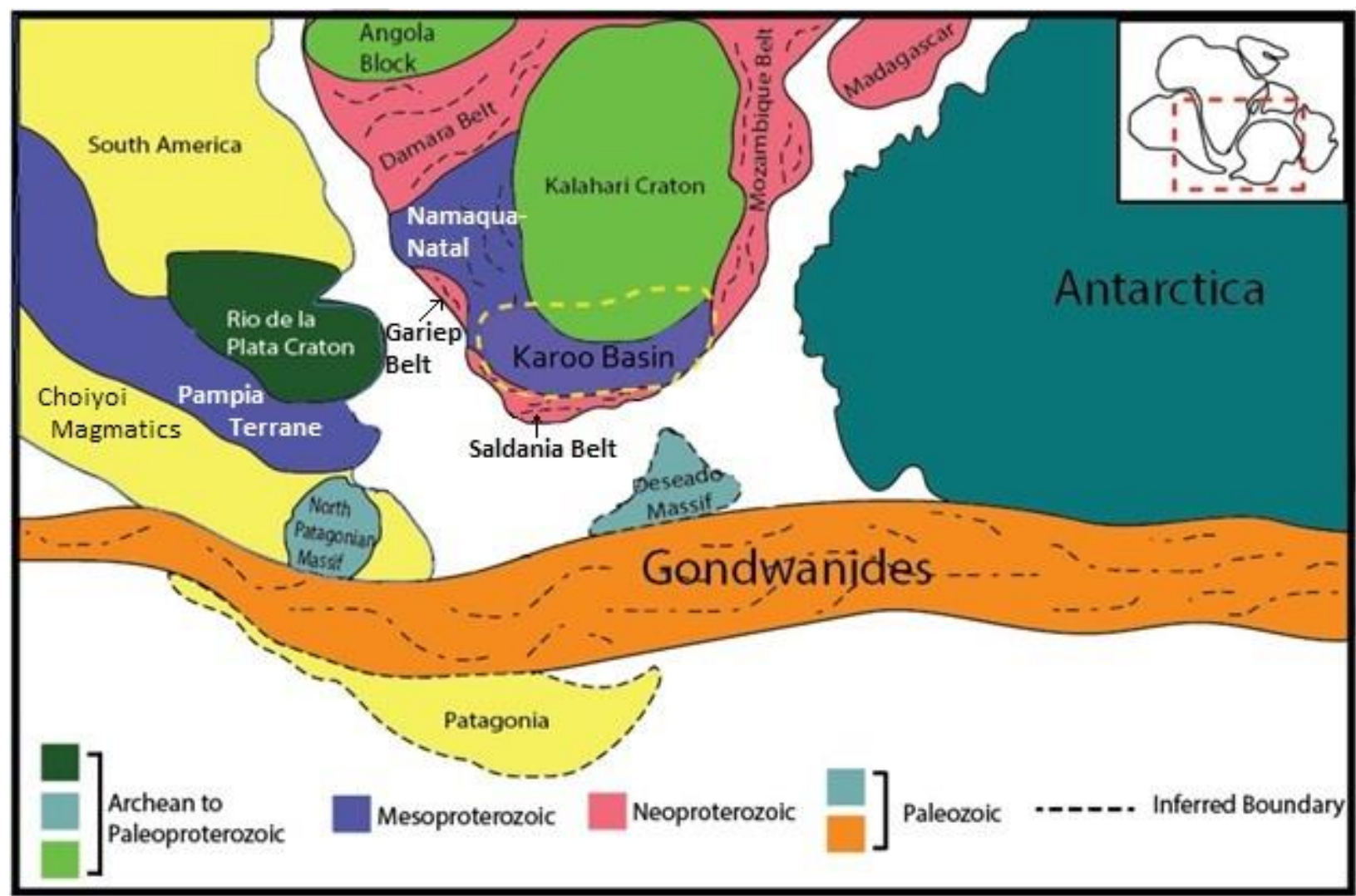

Figure 4: Paleogeographic map of the Permian southern boundary of Gondwana (Modified from Pankhurst et al., 2006; Kleiman and Japas, 2009; Rapela et al., 2011; Uriz et al., 2011; Veevers and Saeed 2013; Vorster 2013, and Dean, 2014).

\section{Chapter 2: Methodology}

Provenance analysis of Ecca and Beaufort Group mudstone includes integration of texture, mineralogy, major element, trace element, rare earth element, and Sm-Nd isotope data integrated with previously published $\mathrm{U}-\mathrm{Pb}$ detrital zircon age, paleoflow, sandstone petrography, Sm-Nd sandstone age, mudstone geochemical, volcanic U-Pb age, and volcanic tuff geochemical composition. Integration of these data permit testing relationships between the Gondwanide Magmatic Arc, deformation in the Cape Fold Belt, the mechanism subsidence in the Karoo Basin, and sedimentation.

\subsection{Sampling}

Fist size ( 500 grams) mudrock samples were taken from the Prince Albert $(n=2)$, Whitehill $(n=2)$, Collingham $(n=2)$, Vischkuil $(n=1)$, Laingsburg $(n=5)$, and Waterford $(n=3)$ formations and from the Abrahamskral Formation of the lower Beaufort Group $(n=3)$ in the Laingsburg subbasin, and from the Prince Albert $(n=2)$, Whitehill $(n=2)$, Collingham $(n=1)$, Ripon ( $n=9)$, Fort Brown $(n=1)$ and Waterford $(n=2)$ formations and the Koonap $(n=2)$ and Balfour ( $n=4)$ formations of the lower Beaufort Group $(n=6)$ in the Ripon subbasin (Figure 5; Table 1). Care was taken to avoid hydrothermally or pedogenically altered samples, and only fresh rock chips were used for analysis. Sample locations are geographically and 
stratigraphically near samples from Dean (2014), McKay et al. (2015) and McKay et al. (2016) (Figure 5).

\section{Laingsburg Depocenter (20.75 E)}

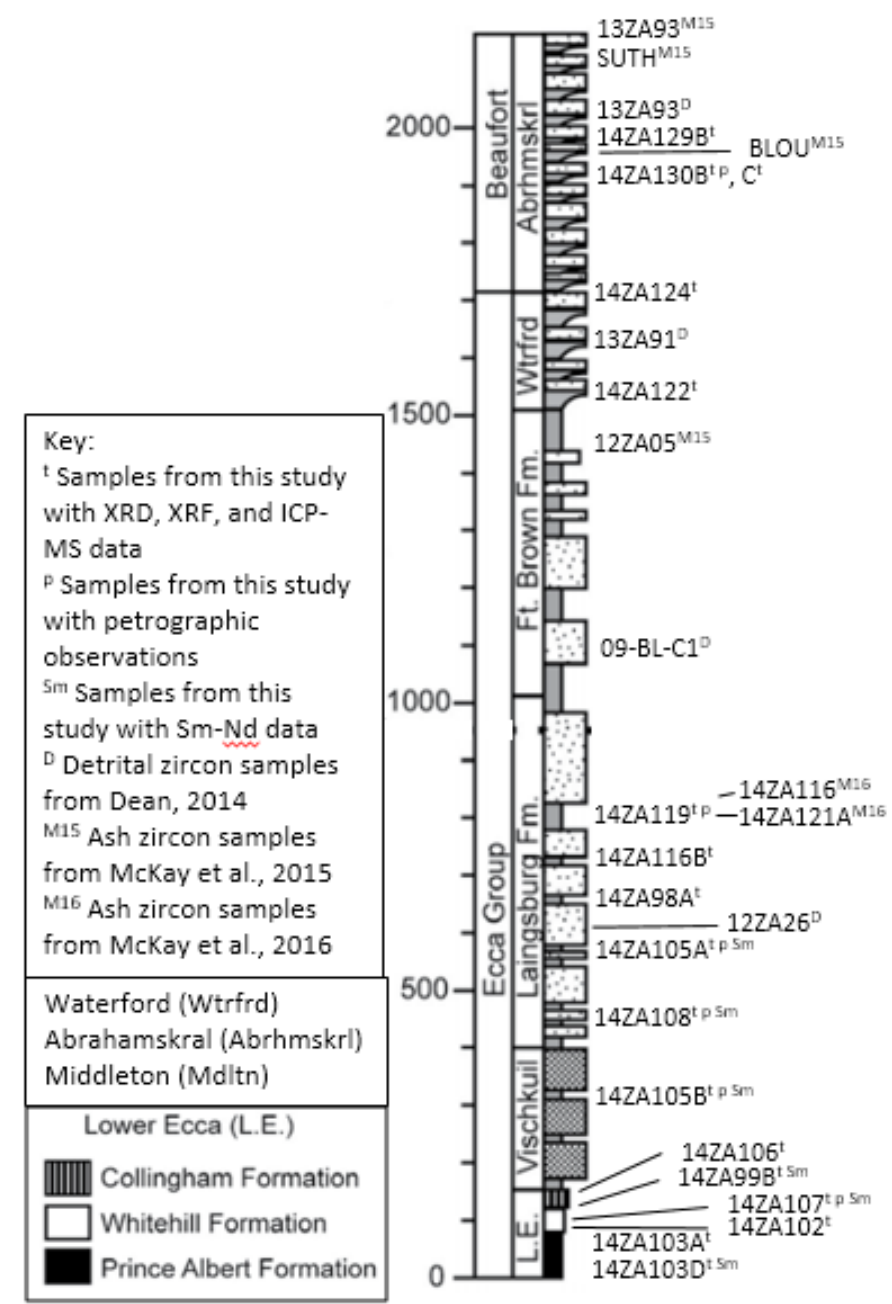

Ripon Depocenter (26.5 E)

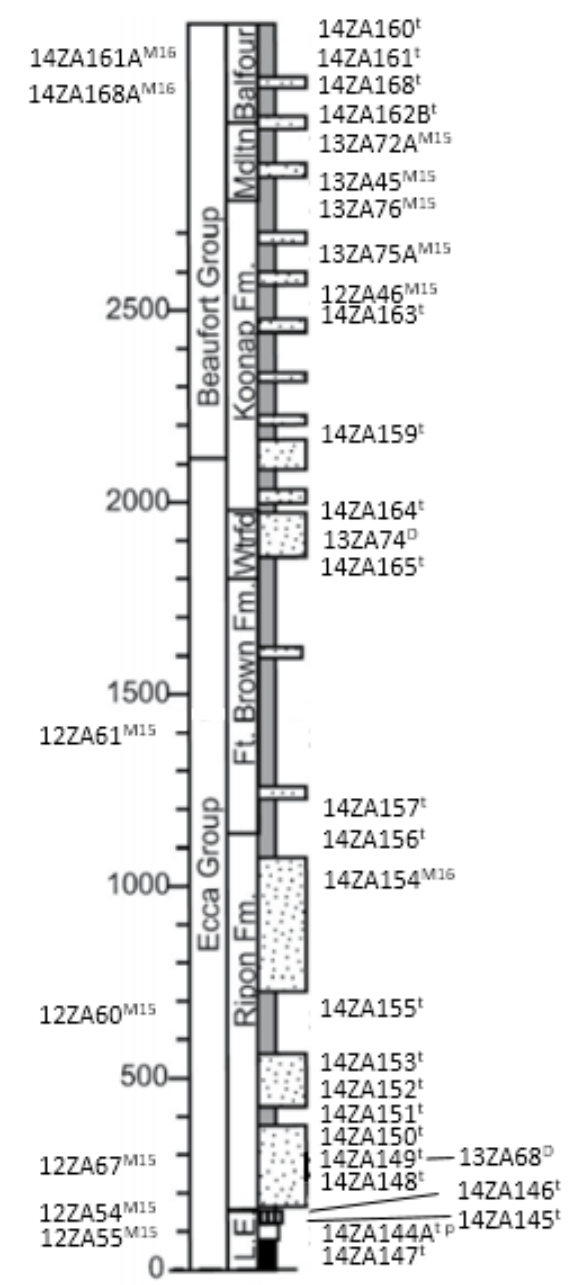

Figure 5: Stratigraphic columns of the Laingsburg and Ripon subbasins with sample locations (Modified after McKay, 2015; Dean, 2014; McKay et al., 2015; McKay et al., 2016).

Table 1: Sample locations with formation name, color description, and analysis performed.

\begin{tabular}{|c|c|c|c|c|c|c|}
\hline Sample & Latitude & Longitude & Subbasin & Formation & Color & Analysis Performed \\
\hline 14ZA147 & $33^{\circ} 12^{\prime} 58.59^{\prime \prime} \mathrm{S}$ & $26^{\circ} 37^{\prime} 38.63^{\prime \prime} \mathrm{E}$ & Ripon & Prince Albert & Black & XRD, XRF, ICP-MS \\
\hline 14ZA144A & $33^{\circ} 12^{\prime} 58.59^{\prime \prime} \mathrm{S}$ & $26^{\circ} 37^{\prime} 38.63^{\prime \prime} \mathrm{E}$ & Ripon & Whitehill & Black & Petrography, XRD, XRF, ICP-MS \\
\hline 14ZA145 & $33^{\circ} 12^{\prime} 56.58^{\prime \prime} \mathrm{S}$ & $26^{\circ} 37^{\prime} 36.86^{\prime \prime} \mathrm{E}$ & Ripon & Collingham & Black & XRD, XRF, ICP-MS \\
\hline 14ZA146 & $33^{\circ} 12^{\prime} 56.58^{\prime \prime} \mathrm{S}$ & $26^{\circ} 37^{\prime} 36.86^{\prime \prime} \mathrm{E}$ & Ripon & Collingham & Black & XRD, XRF, ICP-MS \\
\hline 14ZA148 & $33^{\circ} 12^{\prime} 51.54^{\prime \prime} \mathrm{S}$ & $26^{\circ} 37^{\prime} 25.84^{\prime \prime} \mathrm{E}$ & Ripon & Ripon & $\begin{array}{l}\text { Dark grey - } \\
\text { olive green }\end{array}$ & XRD, XRF, ICP-MS \\
\hline 14ZA149 & $33^{\circ} 12^{\prime} 48.12^{\prime \prime} \mathrm{S}$ & $26^{\circ} 37^{\prime} 21.55^{\prime \prime} \mathrm{E}$ & Ripon & Ripon & $\begin{array}{l}\text { Dark grey - } \\
\text { olive green }\end{array}$ & XRD, XRF, ICP-MS \\
\hline
\end{tabular}




\begin{tabular}{|c|c|c|c|c|c|c|}
\hline 14ZA150 & $33^{\circ} 12^{\prime} 38.68^{\prime \prime} \mathrm{S}$ & $26^{\circ} 37^{\prime} 21.46^{\prime \prime} \mathrm{E}$ & Ripon & Ripon & $\begin{array}{l}\text { Dark grey - } \\
\text { olive green }\end{array}$ & XRD, XRF, ICP-MS \\
\hline 14ZA151 & $33^{\circ} 12^{\prime} 32.79^{\prime \prime} \mathrm{S}$ & $26^{\circ} 37^{\prime} 15.65^{\prime \prime} \mathrm{E}$ & Ripon & Ripon & $\begin{array}{l}\text { Dark grey - } \\
\text { olive green }\end{array}$ & XRD, XRF, ICP-MS \\
\hline 14ZA152 & $33^{\circ} 12^{\prime} 19.12^{\prime \prime} \mathrm{S}$ & $26^{\circ} 37^{\prime} 25.23^{\prime \prime} \mathrm{E}$ & Ripon & Ripon & Black & XRD, XRF, ICP-MS \\
\hline 14ZA153 & $33^{\circ} 12^{\prime} 04.68^{\prime \prime} \mathrm{S}$ & $26^{\circ} 37^{\prime} 08.09^{\prime \prime} \mathrm{E}$ & Ripon & Ripon & $\begin{array}{l}\text { Black - dark } \\
\text { grey }\end{array}$ & XRD, XRF, ICP-MS \\
\hline 14ZA155 & $33^{\circ} 11^{\prime} 48.06^{\prime \prime} \mathrm{S}$ & $26^{\circ} 37^{\prime} 05.24^{\prime \prime} \mathrm{E}$ & Ripon & Ripon & Black & XRD, XRF, ICP-MS \\
\hline 14ZA156 & $33^{\circ} 11^{\prime} 40.16^{\prime \prime} \mathrm{S}$ & $26^{\circ} 37^{\prime} 01.40^{\prime \prime} \mathrm{E}$ & Ripon & Ripon & Brown - green & XRD, XRF, ICP-MS \\
\hline 14ZA157 & $33^{\circ} 11^{\prime} 22.36^{\prime \prime} \mathrm{S}$ & $26^{\circ} 37^{\prime} 09.04^{\prime \prime} \mathrm{E}$ & Ripon & Fort Brown & $\begin{array}{l}\text { Black - dark } \\
\text { grey }\end{array}$ & XRD, XRF, ICP-MS \\
\hline 14ZA165 & $33^{\circ} 03^{\prime} 24.96^{\prime \prime} \mathrm{S}$ & $26^{\circ} 39^{\prime} 04.22^{\prime \prime} \mathrm{E}$ & Ripon & Waterford & Green - grey & XRD, XRF, ICP-MS \\
\hline 14ZA164 & $33^{\circ} 03^{\prime} 24.96^{\prime \prime} \mathrm{S}$ & $26^{\circ} 39^{\prime} 04.22^{\prime \prime} \mathrm{E}$ & Ripon & Waterford & Green - grey & XRD, XRF, ICP-MS \\
\hline 14ZA159 & $33^{\circ} 00^{\prime} 04.56^{\prime \prime} \mathrm{S}$ & $26^{\circ} 39^{\prime} 10.83^{\prime \prime} \mathrm{E}$ & Ripon & Koonap & $\begin{array}{l}\text { Olive green - } \\
\text { grey }\end{array}$ & XRD, XRF, ICP-MS \\
\hline 14ZA163 & $32^{\circ} 43^{\prime} 07.82^{\prime \prime} \mathrm{S}$ & $26^{\circ} 34^{\prime} 56.90^{\prime \prime} \mathrm{E}$ & Ripon & Koonap & Dark grey & XRD, XRF, ICP-MS \\
\hline 14ZA162B & $32^{\circ} 30^{\prime} 34.94 " \mathrm{~S}$ & $26^{\circ} 48^{\prime} 01.14^{\prime \prime} \mathrm{E}$ & Ripon & Balfour & Grey & XRD, XRF, ICP-MS \\
\hline 14ZA168 & $32^{\circ} 07^{\prime} 51.87^{\prime \prime} \mathrm{S}$ & $24^{\circ} 34^{\prime} 31.28^{\prime \prime} \mathrm{E}$ & Ripon & Balfour & Red - purple & XRD, XRF, ICP-MS \\
\hline 14ZA161 & $32^{\circ} 28^{\prime} 54.34^{\prime \prime} \mathrm{S}$ & $26^{\circ} 49^{\prime} 53.01 " \mathrm{E}$ & Ripon & Balfour & Red - purple & XRD, XRF, ICP-MS \\
\hline 14ZA160 & $32^{\circ} 28^{\prime} 54.34^{\prime \prime} \mathrm{S}$ & $26^{\circ} 49^{\prime} 53.01 " \mathrm{E}$ & Ripon & Balfour & $\begin{array}{l}\text { Black - dark } \\
\text { grey }\end{array}$ & XRD, XRF, ICP-MS \\
\hline 14ZA103D & $33^{\circ} 10^{\prime} 57.44^{\prime \prime} \mathrm{S}$ & $20^{\circ} 48^{\prime} 54.77^{\prime \prime} \mathrm{E}$ & Laingsburg & Prince Albert & Black & XRD, XRF, ICP-MS, Sm-Nd \\
\hline 14ZA103A & $33^{\circ} 10^{\prime} 59.47^{\prime \prime} \mathrm{S}$ & $20^{\circ} 49^{\prime} 07.76 " \mathrm{E}$ & Laingsburg & Prince Albert & Black & XRD, XRF, ICP-MS \\
\hline 14ZA102 & $33^{\circ} 11^{\prime} 00.00^{\prime \prime} \mathrm{S}$ & $20^{\circ} 49^{\prime} 07.78^{\prime \prime} \mathrm{E}$ & Laingsburg & Whitehill & Black & XRD, XRF, ICP-MS \\
\hline 14ZA107 & $33^{\circ} 14^{\prime} 20.08^{\prime \prime} \mathrm{S}$ & $20^{\circ} 51^{\prime} 57.99 " \mathrm{E}$ & Laingsburg & Whitehill & Black & $\begin{array}{l}\text { Petrography, XRD, XRF, ICP-MS, Sm- } \\
\text { Nd }\end{array}$ \\
\hline 14ZA99B & $33^{\circ} 11^{\prime} 08.31 " \mathrm{~S}$ & $20^{\circ} 49^{\prime} 11.61 " \mathrm{E}$ & Laingsburg & Collingham & Black & XRF, ICP-MS, Sm-Nd \\
\hline 14ZA106 & $33^{\circ} 14^{\prime} 20.08^{\prime \prime} \mathrm{S}$ & $20^{\circ} 51^{\prime} 57.99 " \mathrm{E}$ & Laingsburg & Collingham & Black & XRD, XRF, ICP-MS \\
\hline 14ZA105B & $33^{\circ} 14^{\prime} 21.31^{\prime \prime} \mathrm{S}$ & $20^{\circ} 51^{\prime} 58.22^{\prime \prime} \mathrm{E}$ & Laingsburg & Vischkuil & Black & $\begin{array}{l}\text { Petrography, XRD, XRF, ICP-MS, Sm- } \\
\text { Nd }\end{array}$ \\
\hline 14ZA108 & $33^{\circ} 14^{\prime} 16.54^{\prime \prime} \mathrm{S}$ & $20^{\circ} 51^{\prime} 55.65 " \mathrm{E}$ & Laingsburg & Laingsburg & Black & $\begin{array}{l}\text { Petrography, XRD, XRF, ICP-MS, Sm- } \\
\text { Nd }\end{array}$ \\
\hline 14ZA105A & $33^{\circ} 13^{\prime} 23.57^{\prime \prime} \mathrm{S}$ & $20^{\circ} 51^{\prime} 55.44^{\prime \prime} \mathrm{E}$ & Laingsburg & Laingsburg & Black & $\begin{array}{l}\text { Petrography, XRD, XRF, ICP-MS, Sm- } \\
\text { Nd }\end{array}$ \\
\hline 14ZA98A & $33^{\circ} 10^{\prime} 37.09^{\prime \prime} \mathrm{S}$ & $20^{\circ} 51^{\prime} 36.73^{\prime \prime} \mathrm{E}$ & Laingsburg & Laingsburg & Black & XRD, XRF, ICP-MS \\
\hline 14ZA116B & $33^{\circ} 13^{\prime} 14.09^{\prime \prime} \mathrm{S}$ & $20^{\circ} 59^{\prime} 00.73 " \mathrm{E}$ & Laingsburg & Laingsburg & Black & XRD, XRF, ICP-MS \\
\hline 14ZA119 & $33^{\circ} 13^{\prime} 02.66^{\prime \prime} \mathrm{S}$ & $20^{\circ} 59^{\prime} 19.86^{\prime \prime} \mathrm{E}$ & Laingsburg & Laingsburg & Black & Petrography, XRD, XRF, ICP-MS \\
\hline 14ZA122 & $33^{\circ} 03^{\prime} 17.05^{\prime \prime} \mathrm{S}$ & $20^{\circ} 35^{\prime} 28.27^{\prime \prime} \mathrm{E}$ & Laingsburg & Waterford & Black & XRD, XRF, ICP-MS \\
\hline 14ZA124 & $32^{\circ} 55^{\prime} 42.35^{\prime \prime} \mathrm{S}$ & $20^{\circ} 33^{\prime} 16.45^{\prime \prime} \mathrm{E}$ & Laingsburg & Waterford & Black-purple & XRD, XRF, ICP-MS \\
\hline 14ZA130B & $32^{\circ} 15^{\prime} 42.31^{\prime \prime} \mathrm{S}$ & $21^{\circ} 38^{\prime} 37.46^{\prime \prime} \mathrm{E}$ & Laingsburg & Abrahamskral & Red-purple & Petrography, XRD, ICP-MS \\
\hline 14ZA129B & $32^{\circ} 05^{\prime} 31.20^{\prime \prime} \mathrm{S}$ & $21^{\circ} 43^{\prime} 34.90^{\prime \prime} \mathrm{E}$ & Laingsburg & Abrahamskral & Red-purple & XRD, XRF, ICP-MS \\
\hline 14ZA130C & $32^{\circ} 15^{\prime} 42.31^{\prime \prime} \mathrm{S}$ & $21^{\circ} 38^{\prime} 37.46^{\prime \prime} \mathrm{E}$ & Laingsburg & Abrahamskral & Green & XRD, XRF, ICP-MS \\
\hline
\end{tabular}




\subsection{Petrography}

Samples from the Whitehill $(\mathrm{n}=1)$, Vischkuil $(\mathrm{n}=1)$, Laingsburg $(\mathrm{n}=3)$, and Abrahamskral ( $\mathrm{n}=1)$ formations in the Laingsburg subbasin, and from the Whitehill $(\mathrm{n}=1)$ Formation in the Ripon subbasin were made into polished thin-sections, and studied with a petrographic microscope to supplement geochemistry as a provenance indicator (Figure 5; Table 1). Thin-section analysis included petrographic description, identification of detrital components and documentation of maximum grain size. Samples were chosen based on quartz content from $\mathrm{XRD}$ analysis and stratigraphic location in order to identify quartz-bearing constituents in the mudrocks.

\subsection{X-ray Diffraction Analysis}

XRD analysis was performed on all samples using a PANalytical X'Pert Pro diffractometer in the Shared Research Facilities at West Virginia University. Samples were prepared for XRD by first picking out unweathered chips, powdering the chips for 0.5-4.0 minutes using a hardened steel grinding container in a SPEX Shatterbox swing mill, and then pressing the powder into a chemplex disc. Time in the Shatterbox swing mill was dependent on the amount of quartz silt and sand in the sample, which takes longer to powder than other minerals. Default mineral identification was first achieved using the PANalytical X'Pert Highscore Plus 4.0 data analysis program with the ICDD PDF 4 diffraction database. Of the hundreds of possible minerals indicated by the program, only minerals likely to be found in shale were chosen from the candidates given by the program. Default automatic Rietveld Analysis was then used to calculate quantitative mineralogy for each sample.

\subsection{X-ray Fluorescence analysis}

Major elements were determined by X-ray fluorescence (XRF) on all samples using a Phillips PW2400 XRF at the University of Alabama. Samples were prepared for XRF by first finely powdering material from that used for XRD analysis for 4-10 minutes using a hardened steel grinding container in a SPEX Shatterbox swing mill until no grit could be felt when the powder was rubbed on a piece of paper, then desiccating samples in a high temperature oven, melting the desiccated powder with lithium borate flux and fusing the melt into a glass disc in a platinum-coated mold to prevent sticking. Standard AGV-1 was analyzed at the beginning of each run, and each sample was analyzed five times to ensure accuracy. Whole-rock major element composition was used to calculate chemical index of alteration (CIA) and index of compositional variability (ICV), as well as various plots of major elements.

CIA is a quantitative measure of chemical weathering, in which values increase as weathering increases. High CIA values result from the removal of unstable feldspars (containing elements $\mathrm{Ca}^{2+}, \mathrm{Na}^{+}, \mathrm{K}^{+}$) from the sample and enrichment of stable minerals such as illite and kaolinite clays (containing elements $\mathrm{Al}^{3+}, \mathrm{Ti}^{4+}$ ) due to the interactions of the minerals with water (Nesbitt and Young, 1982, 1984, 1989; McLennan et al., 1993; Fedo et al., 1995). The formula is:

$$
\begin{aligned}
& \mathrm{CIA}=\left(\mathrm{Al}_{2} \mathrm{O}_{3} /\left(\mathrm{Al}_{2} \mathrm{O}_{3}+\mathrm{CaO}^{*}+\mathrm{Na}_{2} \mathrm{O}+\mathrm{K}_{2} \mathrm{O}\right)\right) \times 100 \\
& \mathrm{CaO}^{*}=\mathrm{mol} \mathrm{CaO}-\mathrm{mol} \mathrm{CO}_{2} \text { calcite }-(0.5 \times \mathrm{mol} \mathrm{CO})_{\text {dolomite }}-\left((10 / 3) \times \mathrm{mol}_{2} \mathrm{O}_{5}\right)_{\text {apatite }}
\end{aligned}
$$


in which $\mathrm{CaO}^{*}$ is the calcium content of the sample with $\mathrm{Ca}$ contained in carbonates and apatite removed. Carbonate and apatite content were determined by XRD analysis. The Index of Compositional Variability (ICV) is similar to CIA, but takes into account amounts of iron, magnesium, manganese, and titanium and so reflects the weathering of amphibole and pyroxene to clay (Cox et al., 1995). In contrast to CIA, ICV decreases with increased weathering. CIA and ICV represent the intensity of chemical weathering of the source rock. The formula is:

\section{$\mathrm{ICV}=\left(\mathrm{CaO}+\mathrm{Na}_{2} \mathrm{O}+\mathrm{K}_{2} \mathrm{O}+\mathrm{Fe}_{2} \mathrm{O}_{3}+\mathrm{MgO}+\mathrm{MnO}+\mathrm{TiO}_{2}\right) / \mathrm{Al}_{2} \mathrm{O}_{3}$}

The A-CN-K $\left(\mathrm{Al}_{2} \mathrm{O}_{3}-\left(\mathrm{CaO}^{*}+\mathrm{Na}_{2} \mathrm{O}\right)-\mathrm{K}_{2} \mathrm{O}\right)$ diagram uses proportions of aluminum, calcium, sodium, and potassium in the samples to estimate both the initial compositions of source rocks and CIA values for the sample (Nesbitt and Young, 1989; McLennan et al., 1990; Fedo et al., 1995). Weathering trends reflected by sample composition can be compared with mafic and felsic rock types such as basalt and granite, as well as with the composition of average upper crust (Nesbitt and Young, 1989; McLennan et al., 1990; Fedo et al., 1995).

\subsection{ICP-MS Analysis}

Thirteen trace elements (Ba, Th, Nb, Y, Hf, Ta, U, Pb, Rb, Cs, Sr, Sc, and Zr) and fourteen rare earth elements (REE; La, Ce, Pr, Nd, Sm, Eu, Gd, Tb, Dy, Ho, Er, Tm, Yb, and Lu) were analyzed in all samples by inductively coupled plasma mass spectrometry (ICP-MS) at Washington State University. Fresh rock chips from the samples were sent to Washington State University. At Washington State, about two grams of each sample was ground to a powder, fused with di-Lithium-tetraborate, re-ground, dissolved in $\mathrm{HNO}_{3}, \mathrm{HF}$, and $\mathrm{HClO}_{4}$, and then diluted with de-ionized water to a final dilution factor of 1:4800 relative to the amount of sample fused. The dissolved samples were then analyzed with an Agilent model 4500 ICP-MS.

The Eu anomaly $\left(\mathrm{Eu} / \mathrm{Eu}^{*}\right)$ is the measurement of depletion or enrichment of $\mathrm{Eu}$ compared to REE both smaller and larger, samarium $(\mathrm{Sm})$ and gadolinium $(\mathrm{Gd}) . \mathrm{Eu}^{2+}$ can be substituted for $\mathrm{Ca}$ in plagioclase, therefore a negative Eu-anomaly indicates the either precipitation of Eu-enriched plagioclase out of the parent magma or intracrustal partial melting of plagioclase from the upper crust leaving the crust depleted in Eu (McLennan et al., 1993; Atwood, 2013).

$$
\mathbf{E u} / \mathbf{E u}^{*}=\mathbf{E u}_{\mathbf{N}} /\left(\mathrm{Sm}_{\mathbf{N}} * \mathbf{G d}_{\mathbf{N}}\right)^{1 / 2}
$$

in which the subscript $\mathrm{N}$ indicates normalization to chondritic meteorite. Eu/Eu* less than 0.95 indicates depletion of $\mathrm{Eu}$, whereas a value greater than 1.05 indicates enrichment (Taylor and McLennan et al., 1985). N-MORB (values of Sun and McDonough, 1989) normalized multielement spider diagrams (Pearce, 1983) and chondrite meteorite (values of Evensen et al., 1978) normalized REE diagrams are used to characterize source terrane patterns (Pearce, 1983; McLennan et al., 1993). 


\subsection{Samarium and Neodymium Isotopes}

Samarium $(\mathrm{Sm})$ and neodymium $(\mathrm{Nd})$ isotopic composition was analyzed by thermal ionization mass spectrometry at Actlabs on six samples from the Laingsburg subbasin (one from each of the Prince Albert, Whitehill, Collingham, and Vischkuil formations, and two from the Laingsburg Formation). Samples from these formations were chosen to study the change in provenance between the base to the top of the Ecca Group, but the budget only allowed for six samples to be analyzed. Sm and Nd are LREE that can be used to date the formation of igneous rocks (DePaolo and Wasserburg, 1976b; Dickin, 1995; Winter, 2010). ${ }^{147} \mathrm{Sm}$ decays to ${ }^{143} \mathrm{Nd}$ by alpha decay, and ${ }^{144} \mathrm{Nd}$ is a stable $\mathrm{Nd}$ isotope, so the ratio ${ }^{143} \mathrm{Nd} /{ }^{144} \mathrm{Nd}$ increases with time as $\mathrm{Sm}$ decays to ${ }^{143} \mathrm{Nd}$. This ratio can be compared to the initial ratio of the chondritic uniform reservoir to find the degree of $\mathrm{Nd}$ enrichment $(\varepsilon \mathrm{Nd})$ and a chondritic model age ( $\left.\mathrm{T}_{\mathrm{CHUR}}\right)$. $\varepsilon \mathrm{Nd}$ represents the deviation of the sample from chondritic meteorite values, while $\mathrm{T}_{\mathrm{CHUR}}$ represents the deviation of the sample from mantle values. The formulas are:

$$
\begin{gathered}
\varepsilon N d(t)=\left(\left(\left({ }^{143} \mathrm{Nd} /{ }^{144} \mathrm{Nd}_{\text {sample(t) }}\right) /\left({ }^{143} \mathrm{Nd} /{ }^{144} \mathrm{NdCHUR}(\mathrm{t})\right)\right)-1\right) * 10^{4} \\
T_{\text {ChUR }}=(1 / \lambda) * \ln \left(1+\left(\left(\left({ }^{143} \mathrm{Nd} /{ }^{144} \mathrm{Nd}_{\text {sample }}\right)-\left(\left({ }^{143} \mathrm{Nd} /{ }^{144} \mathrm{Nd} \text { CHUR }\right)\right) /\left(\left({ }^{147} \mathrm{Sm} /{ }^{144} \mathrm{Nd}_{\text {sample }}\right)-\right.\right.\right.\right. \\
\left.\left({ }^{147} \mathrm{Sm} /{ }^{144} \mathrm{Nd} \mathrm{CHUR}\right)\right)
\end{gathered}
$$

in which (t) represents the time at which $\varepsilon N d$ is calculated, $\lambda$ represents the decay constant for ${ }^{147} \mathrm{Sm}\left(6.54 \mathrm{e}^{-12} \mathrm{yr}^{-1}\right),{ }^{143} \mathrm{Nd} /{ }^{144} \mathrm{Nd}_{\mathrm{CHUR}}=0.5126$ (present day) and ${ }^{147} \mathrm{Sm} /{ }^{144} \mathrm{Nd}_{\mathrm{CHUR}}=0.1967$ (present day) (DePaolo and Wasserburg, 1976; Dickin, 1995; Winter, 2010). A lower $\varepsilon N d$ would reflect an older age in crustal rocks, and $\mathrm{T}_{\mathrm{CHUR}}$ is a representation of age of the source rock.

\section{Chapter 3: Results}

\subsection{Petrography Results}

Observations from thin-sections show variability in cement and matrix mineralogy, grainsize, and sorting (Table 2). All of the samples contain a clay matrix and authigenic microcrystalline quartz cement in varying amounts. The Whitehill Formation sample from the Ripon subbasin contains the most authigenic quartz cement (95\%) (Figure 6). All samples contain clay, silt and sand size grains in varying amounts, but clay and silt constitute the majority of the grains. The samples range from well-sorted to very well-sorted. Sample 14ZA105A from the Laingsburg Formation contains the least clay (5\%) and possibly the most silt (85\%), but it is difficult to differentiate between detrital and authigenic quartz in this sample (Figure 7). All samples contain randomly oriented, angular - subangular, low sphericity silt - fine sand size

mica grains (Figures 6,7,8). The Whitehill and Laingsburg formations of the Laingsburg subbasin contain silt - fine sand size, sub-angular - sub-rounded, moderate - high sphericity, mono- and polycrystalline quartz grains (Figures 8 and 9). Clay in the samples is light brown, dark brown/black, or red-brown in color. 

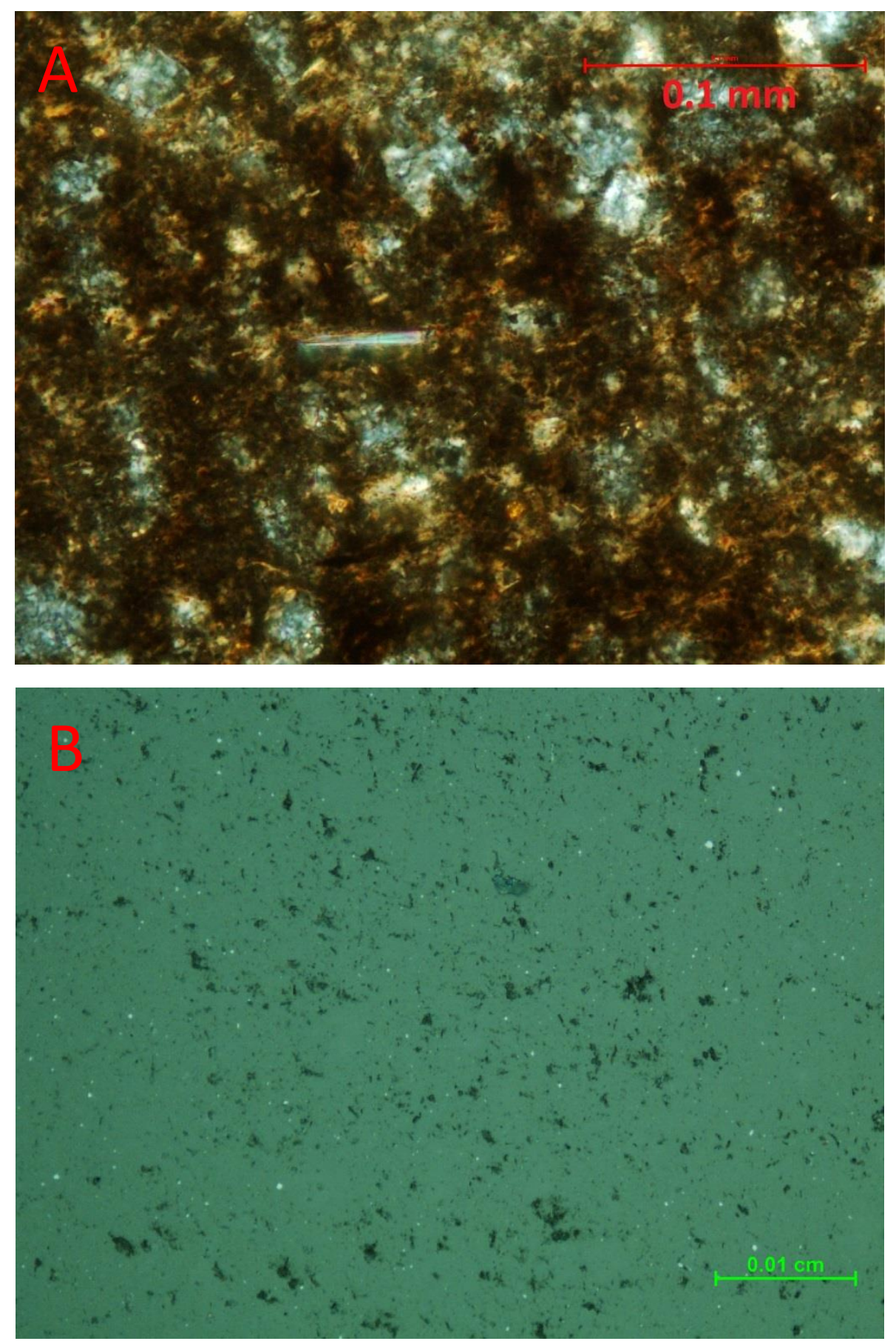

Figure 6: Sample 14ZA144A (Whitehill Fm., Ripon subbasin) with clay and authigenic microcrystalline quartz/chert. The two images are from different locations on the thin section. Image A) 40x magnification, transmitted light, cross-polarized light; an elongate mica grain, black/brown clay, and microcrystalline quartz can be seen. B) 20x magnification, reflected light; the surface is smooth, no grains are observed with reflected light. 


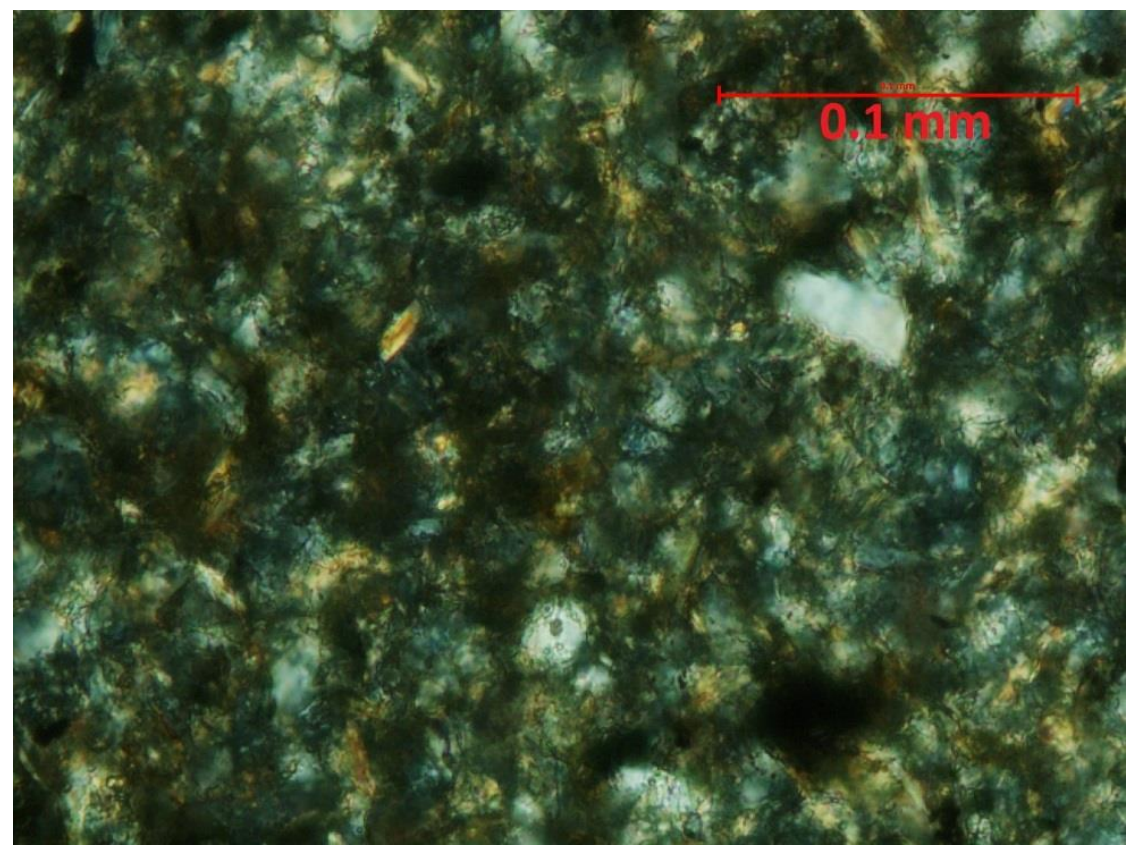

Figure 7: Sample 14ZA105A (Laingsburg Fm., Laingsburg subbasin) with detrital quartz silt, authigenic quartz, and mica silt grains. Image is at 40x magnification using transmitted light and cross-polarized light.

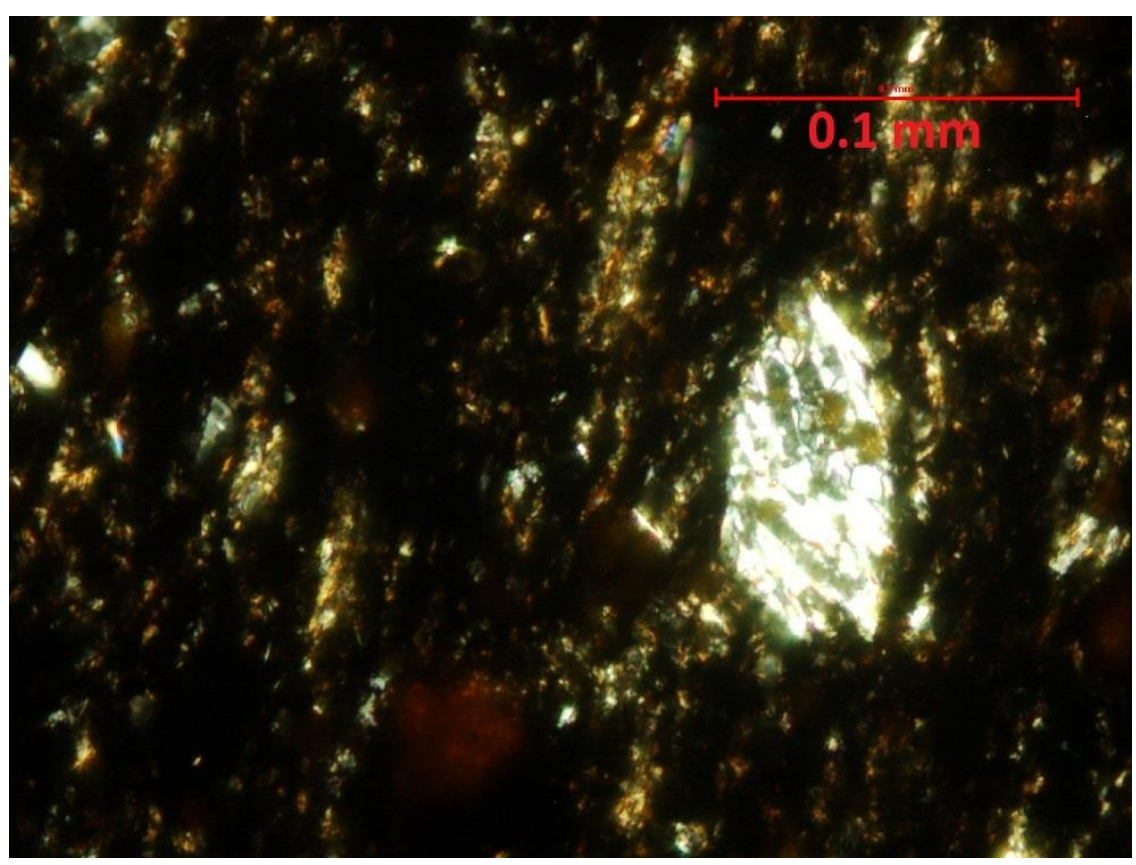

Figure 8: Sample 14ZA107 (Whitehill Fm., Laingsburg subbasin) with a detrital polycrystalline quartz sand grain, authigenic quartz, and mica silt grains. Image is at 40x magnification using transmitted light and cross-polarized light. 


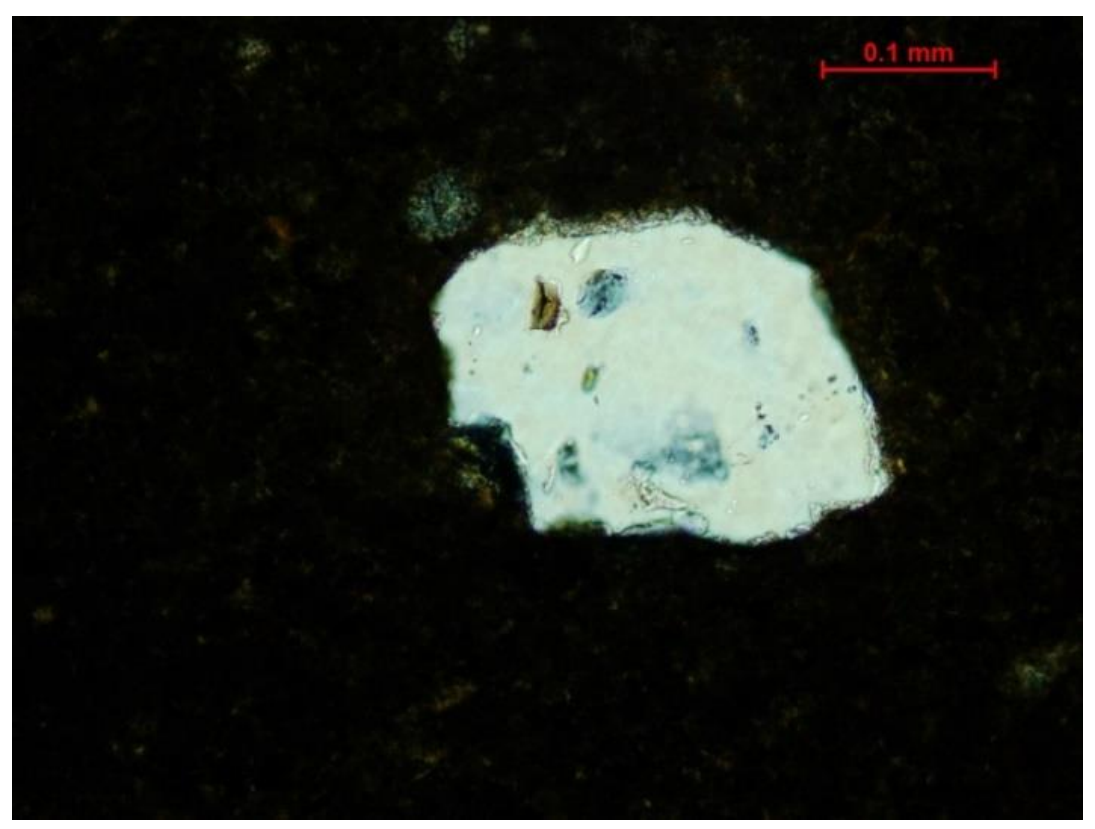

Figure 9: Sample 14ZA119 (Laingsburg Fm., Laingsburg subbasin) with detrital quartz sand grain that has mineral inclusions and vacuoles. Image is at 20x magnification using cross-polarized light.

Table 2: Petrographic Observations

\begin{tabular}{|c|c|c|c|c|c|}
\hline Sample Name & Grain Size & Sorting & Roundness & Mineralogy & Cement/Matrix \\
\hline $\begin{array}{l}\text { 14ZA107 } \\
\text { Whitehill Fm } \\
\text { Laingsburg } \\
\text { Subbasin }\end{array}$ & $\begin{array}{l}\text { Clay }-80 \% \\
\text { Silt - 15\% } \\
\text { Very fine- } \\
\text { medium sand } \\
-5 \%\end{array}$ & $\begin{array}{l}\text { Very well- } \\
\text { sorted }\end{array}$ & $\begin{array}{l}\text { Subangular- } \\
\text { subrounded }\end{array}$ & $\begin{array}{l}\text { Black Clay - } \\
80 \% \\
\text { Quartz silt and } \\
\text { sand - } 15 \% \\
\text { Mica silt and } \\
\text { sand - } 5 \%\end{array}$ & $\begin{array}{l}\text { Black matrix - } \\
80 \% \\
\text { Microcrystalline } \\
\text { quartz cement } \\
-20 \%\end{array}$ \\
\hline $\begin{array}{l}\text { 14ZA105B } \\
\text { Vischkuil Fm } \\
\text { Laingsburg } \\
\text { Subbasin }\end{array}$ & $\begin{array}{l}\text { Clay - } 95 \% \\
\text { Silt - } 2 \% \\
\text { Very fine } \\
\text { sand - } 2 \%\end{array}$ & $\begin{array}{l}\text { Very well- } \\
\text { sorted }\end{array}$ & Well-rounded & $\begin{array}{l}\text { Microcrystalline } \\
\text { quartz-65\% } \\
\text { Light brown } \\
\text { clay- } 25 \% \\
\text { Organics - } 5 \% \\
\text { Mica silt and } \\
\text { sand - } 5 \%\end{array}$ & $\begin{array}{l}\text { Microcrystalline } \\
\text { quartz cement- } \\
70 \% \\
\text { Light brown } \\
\text { matrix }-30 \%\end{array}$ \\
\hline $\begin{array}{l}\text { 14ZA108 } \\
\text { Laingsburg Fm } \\
\text { Laingsburg } \\
\text { Subbasin }\end{array}$ & $\begin{array}{l}\text { Clay }-50 \% \\
\text { Silt }-40 \% \\
\text { Very fine - } \\
\text { medium sand } \\
-10 \%\end{array}$ & $\begin{array}{l}\text { Very well- } \\
\text { sorted }\end{array}$ & $\begin{array}{l}\text { Angular- } \\
\text { subangular }\end{array}$ & $\begin{array}{l}\text { Brown clay- } \\
50 \% \\
\text { Angular, } \\
\text { opaque silt and } \\
\text { sand - } 35 \% \\
\text { Quartz silt and } \\
\text { sand - } 10 \% \\
\text { Mica silt and } \\
\text { sand - } 5 \%\end{array}$ & $\begin{array}{l}\text { Quartz cement } \\
-70 \% \\
\text { Brown matrix - } \\
30 \%\end{array}$ \\
\hline $\begin{array}{l}\text { 14ZA105A } \\
\text { Laingsburg Fm }\end{array}$ & $\begin{array}{l}\text { Silt }-85 \% \\
\text { Sand }-10 \% \\
\text { Clay }-5 \%\end{array}$ & $\begin{array}{l}\text { Very well- } \\
\text { Sorted }\end{array}$ & $\begin{array}{l}\text { Subangular- } \\
\text { subrounded }\end{array}$ & $\begin{array}{l}\text { Quartz silt and } \\
\text { sand }-90 \%\end{array}$ & $\begin{array}{l}\text { Quartz cement } \\
-50 \%\end{array}$ \\
\hline
\end{tabular}




\begin{tabular}{|c|c|c|c|c|c|}
\hline $\begin{array}{l}\text { Laingsburg } \\
\text { Subbasin }\end{array}$ & & & & $\begin{array}{l}\text { Brown/yellow } \\
\text { clay - } 5 \% \\
\text { Mica silt - } 5 \%\end{array}$ & $\begin{array}{l}\text { Brown matrix- } \\
50 \%\end{array}$ \\
\hline $\begin{array}{l}\text { 14ZA119 } \\
\text { Laingsburg Fm } \\
\text { Laingsburg } \\
\text { Subbasin }\end{array}$ & $\begin{array}{l}\text { Clay }-90 \% \\
\text { Silt }-5 \% \\
\text { Sand }-\% 5\end{array}$ & Well-sorted & Subrounded & $\begin{array}{l}\text { Light brown } \\
\text { clay - } 90 \% \\
\text { Quartz silt and } \\
\text { sand - } 8 \% \\
\text { Mica silt - } 2 \%\end{array}$ & $\begin{array}{l}\text { Quartz cement } \\
-50 \% \\
\text { Light brown } \\
\text { matrix }-50 \%\end{array}$ \\
\hline $\begin{array}{l}\text { 14ZA130B } \\
\text { Abrahamskral } \\
\text { Fm } \\
\text { Laingsburg } \\
\text { Subbasin }\end{array}$ & $\begin{array}{l}\text { Clay - 95\% } \\
\text { Silt - } 2 \% \\
\text { Very fine } \\
\text { sand- } 2 \%\end{array}$ & $\begin{array}{l}\text { Very well- } \\
\text { sorted }\end{array}$ & Well-rounded & $\begin{array}{l}\text { Microcrystalline } \\
\text { quartz-55\% } \\
\text { Light brown } \\
\text { clay-35\% } \\
\text { Organics - } 5 \% \\
\text { Mica silt and } \\
\text { sand - 5\% }\end{array}$ & $\begin{array}{l}\text { Microcrystalline } \\
\text { quartz cement- } \\
65 \% \\
\text { Light brown } \\
\text { matrix }-35 \%\end{array}$ \\
\hline $\begin{array}{l}\text { 14ZA144A } \\
\text { Whitehill Fm } \\
\text { Ripon } \\
\text { Subbasin }\end{array}$ & $\begin{array}{l}\text { Clay }-95 \% \\
\text { Silt }-5 \%\end{array}$ & $\begin{array}{l}\text { Very well- } \\
\text { sorted }\end{array}$ & Subangular & $\begin{array}{l}\text { Red/brown clay } \\
-95 \% \\
\text { Quartz silt - } 2 \% \\
\text { Mica silt - } 2 \%\end{array}$ & $\begin{array}{l}\text { Microcrystalline } \\
\text { quartz cement } \\
-60 \% \\
\text { Red brown } \\
\text { matrix }-40 \%\end{array}$ \\
\hline
\end{tabular}

\subsection{Mineralogy Results}

\subsubsection{Laingsburg Subbasin}

Quartz, smectite, illite, chlorite, albite and muscovite are ubiquitous (Figure 10; Appendix I). Average mineralogical composition for 16 samples in the Laingsburg subbasin is $32.8 \%$ (standard deviation $(\mathrm{s})=7.9 \%$ ) quartz, $29.1 \%(\mathrm{~s}=10.2 \%)$ muscovite, $16.6 \%(\mathrm{~s}=4.8 \%)$ albite, 5.6\% ( $\mathrm{s}=6.8 \%)$ chlorite, and $15.6 \%(\mathrm{~s}=11.3 \%)$ illite. Quartz decreases overall upsection, with the lower Prince Albert Formation sample containing the highest abundance of quartz (53.7\%) and the lower sample of the Waterford Formation containing the lowest abundance of quartz $(23.5 \%)$. Muscovite content fluctuates from $8.1 \%$ in the upper sample from the Collingham Formation to $46.4 \%$ in a sample from the middle of the Laingsburg Formation and overall the 16 samples from this subbasin do not display a trend with respect to stratigraphic position. Albite fluctuates from $7.8 \%$ in a sample from the Prince Albert Formation to $25.9 \%$ in a sample from the Laingsburg Formation. Overall albite decreases upsection, but spikes in the Collingham Formation sample $(24.4 \%)$ and the overlying Laingsburg Formation sample (25.9\%). Chlorite is nonexistent in all the lowermost formations of the Ecca Group except the lower sample from the Prince Albert, and appears in the Vischkuil and Laingsburg formations, where 6 samples display fluctuations between $1.7 \%$ and $17.4 \%$. Upsection, chlorite is only present in the upper Waterford Formation sample (2.1\%) and the middle Abrahamskral Formation sample (10.8\%). Biotite, vermiculite, apatite, and zeolite were detected in samples occasionally, but in quantities less than $1 \%$ of the sample. Other minerals typically found in shales, such as calcite, dolomite, kaolinite and smectite, were not detected by XRD. 


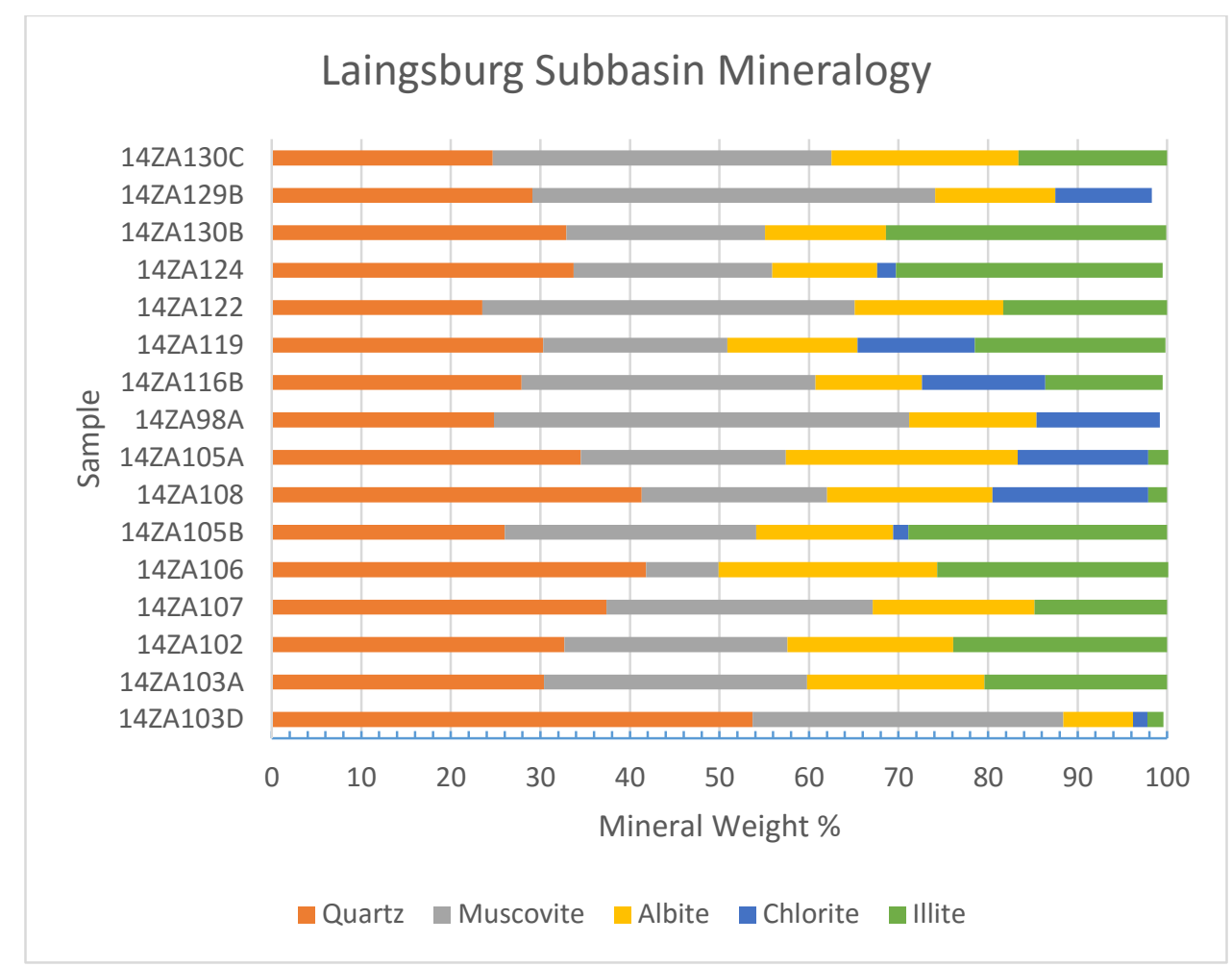

Figure 10: Mineralogy of samples from the Laingsburg subbasin in stratigraphic order.

\subsubsection{Ripon Subbasin}

The average mineralogical content for 21 samples in the Ripon subbasin is $32.9 \%$ $(\mathrm{s}=13.5 \%)$ quartz, 37.3\% ( $\mathrm{s}=10.9 \%)$ muscovite, $11.9 \%(\mathrm{~s}=8.8 \%)$ albite, $5.5 \%(\mathrm{~s}=10.1 \%)$ chlorite, and $11.0 \%$ ( $(\mathrm{s}=14.2 \%$ ) illite (Figure 11). Quartz fluctuates from $13.1 \%$ to $82.6 \%$ in the samples. The sample from the Whitehill Formation contains the most abundant quartz (82.6\%) and the lower Collingham Formation sample contains the second highest quartz content at 43.5. . Muscovite content fluctuates from 16.8\% (Whitehill Formation) to 56.2\% (Ripon Formation). Albite is absent in the Prince Albert, Whitehill, and upper Collingham formations, but constitutes $31 \%$ of the uppermost sample from the Ripon Formation. Chlorite is abundant in the Prince Albert Formation sample (38.2\%) but nearly absent in the Whitehill, Collingham, and lower half of the Ripon Formation. Chlorite fluctuates between 1.9\% and 21.7\% in the 6 Ripon, Fort Brown, and lower Waterford Formation samples, and is $15.1 \%$ of one Balfour Formation sample. 


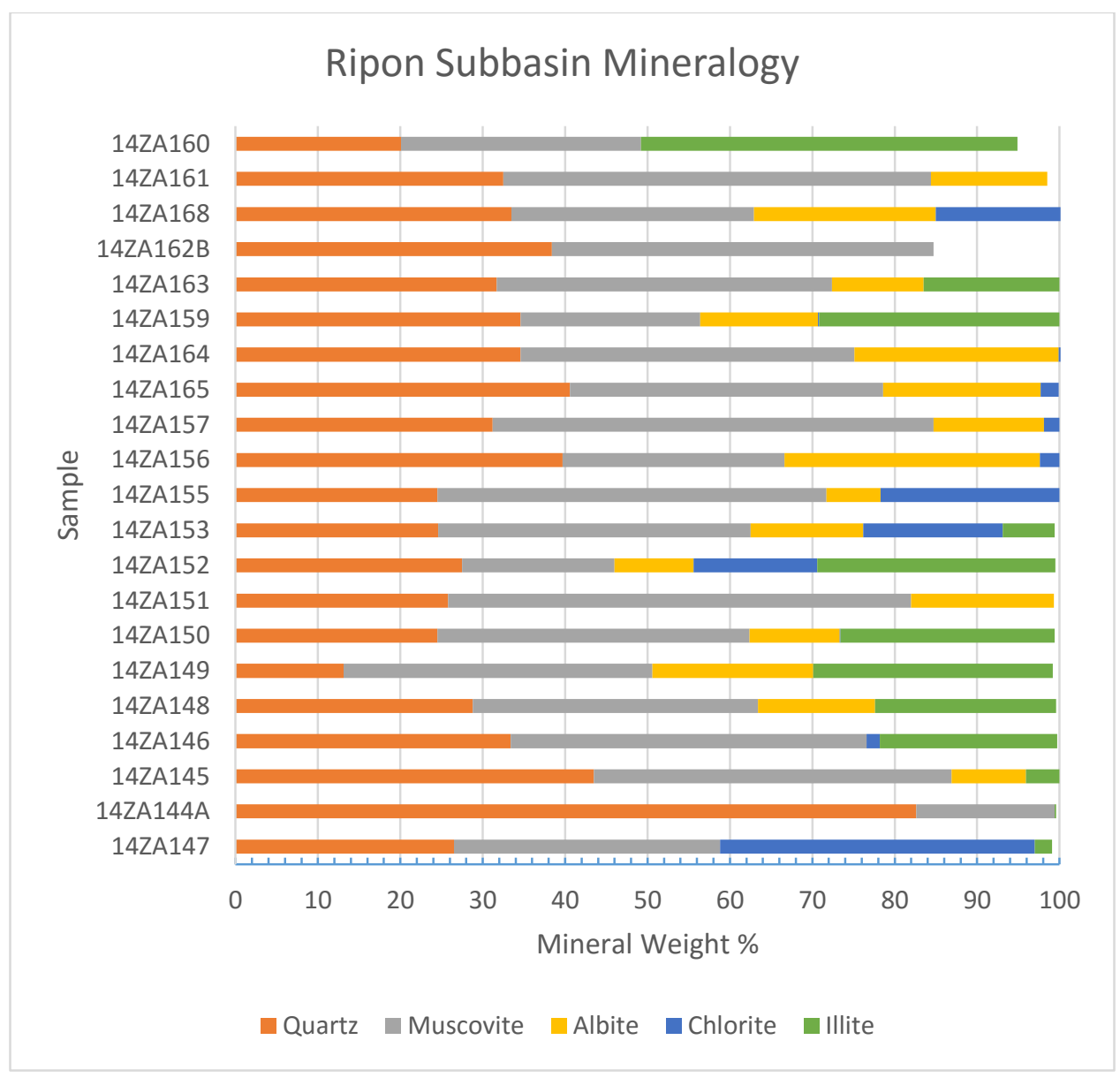

Figure 11: Mineralogy of samples from the Ripon subbasin in stratigraphic order.

\subsection{Major Element Results}

\subsubsection{Laingsburg Subbasin}

$\mathrm{SiO}_{2}$ content varies in the Laingsburg subbasin from 77\% (Prince Albert Formation) to $60.1 \%$ (Laingsburg Formation) (Appendix II). $\mathrm{SiO}_{2}$ averaged $66.4 \%(\mathrm{~s}=4.9 \%$ ) and is fairly close to the North American Shale Composite average for $\mathrm{SiO}_{2}$ (64.8\%) (Gromet et al., 1984), but in order from greatest to least $\mathrm{SiO}_{2}$ content, samples from the lower Prince Albert, upper Collingham, lower Whitehill, upper Whitehill, Vischkuil, 14ZA108 from the Laingsburg, 14ZA105A from the Laingsburg, and from the upper Prince Albert are enriched in $\mathrm{SiO}_{2}$ with respect to the NASC average. The rest of the major element oxide contents are only slightly above NASC measurements, except for $\mathrm{MgO}$ (average $=1.7 \%$; $\mathrm{s}=0.58 \%$ ) and $\mathrm{CaO}$ (average $=0.7 \% ; \mathrm{s}=0.36 \%$ ) which are significantly below the NASC averages for those elements (2.85\% and $3.56 \%$, respectively) (Gromet et al., 1984). 


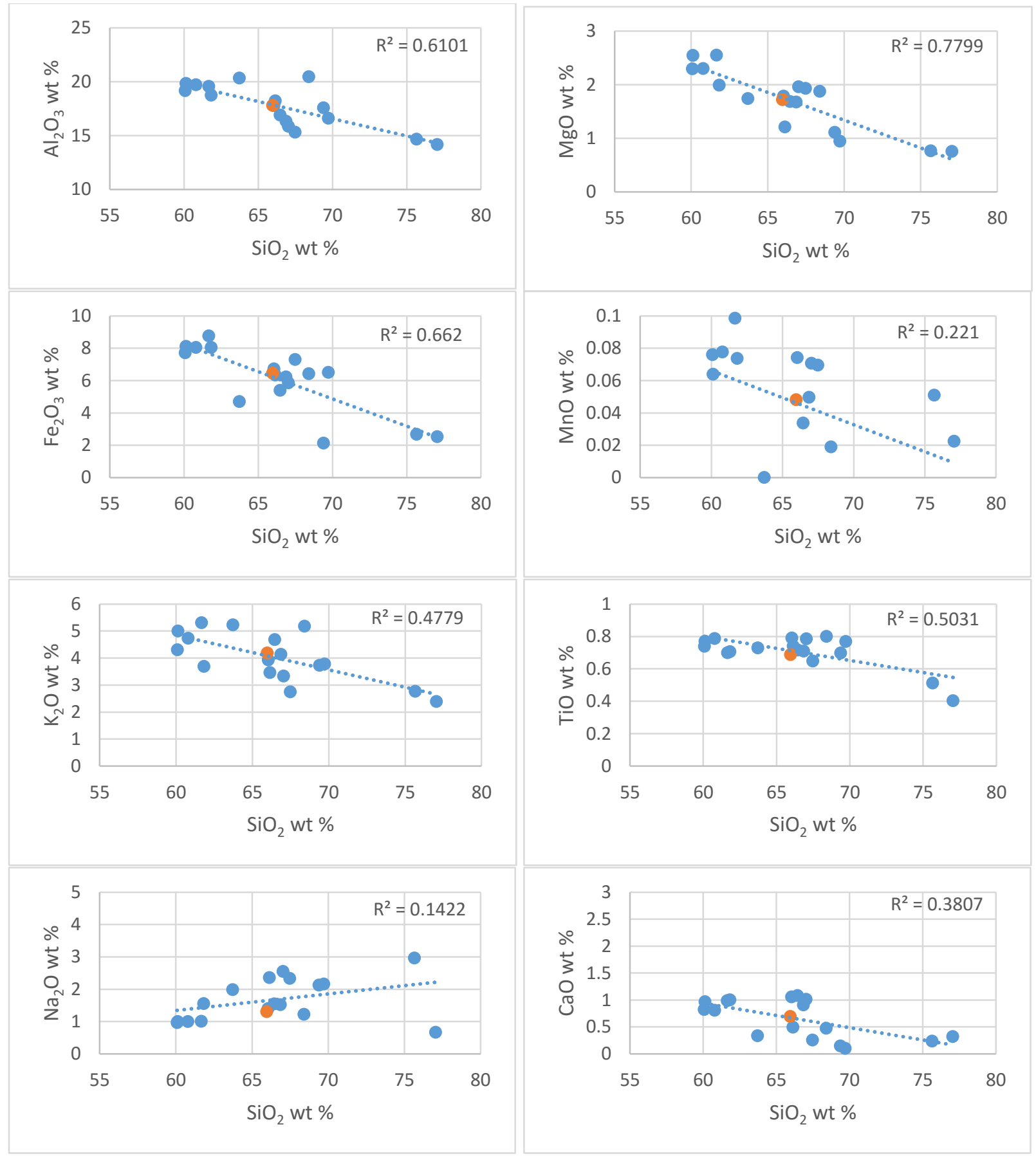

Figure 12: Plots of major elements from samples of the Laingsburg Subbasin (Blue) and NASC averages (Orange; data from Gromet et al., 1984).

CIA values show a weak decreasing trend in CIA is observed upward through section (Figure 13). CIA averaged $68.2(\mathrm{~s}=3.35)$, but the lower Prince Albert Formation sample yielded the highest CIA value at 76.8 and a few samples in the Collingham (63.8) and Laingsburg (62.2) formations are lower. This decrease in CIA reflects less weathering of the sediment. ICV values averaged $0.84(\mathrm{~s}=0.14)$. ICV values increase upsection from 0.5 for the sample in the lower Prince Albert Formation to 0.8 for the sample at the base of the Laingsburg Formation, and then 
remains high $(\sim 0.9)$ throughout the remaining 10 Ecca and Beaufort Group samples. This increase in ICV reflects less weathering of the sediment.

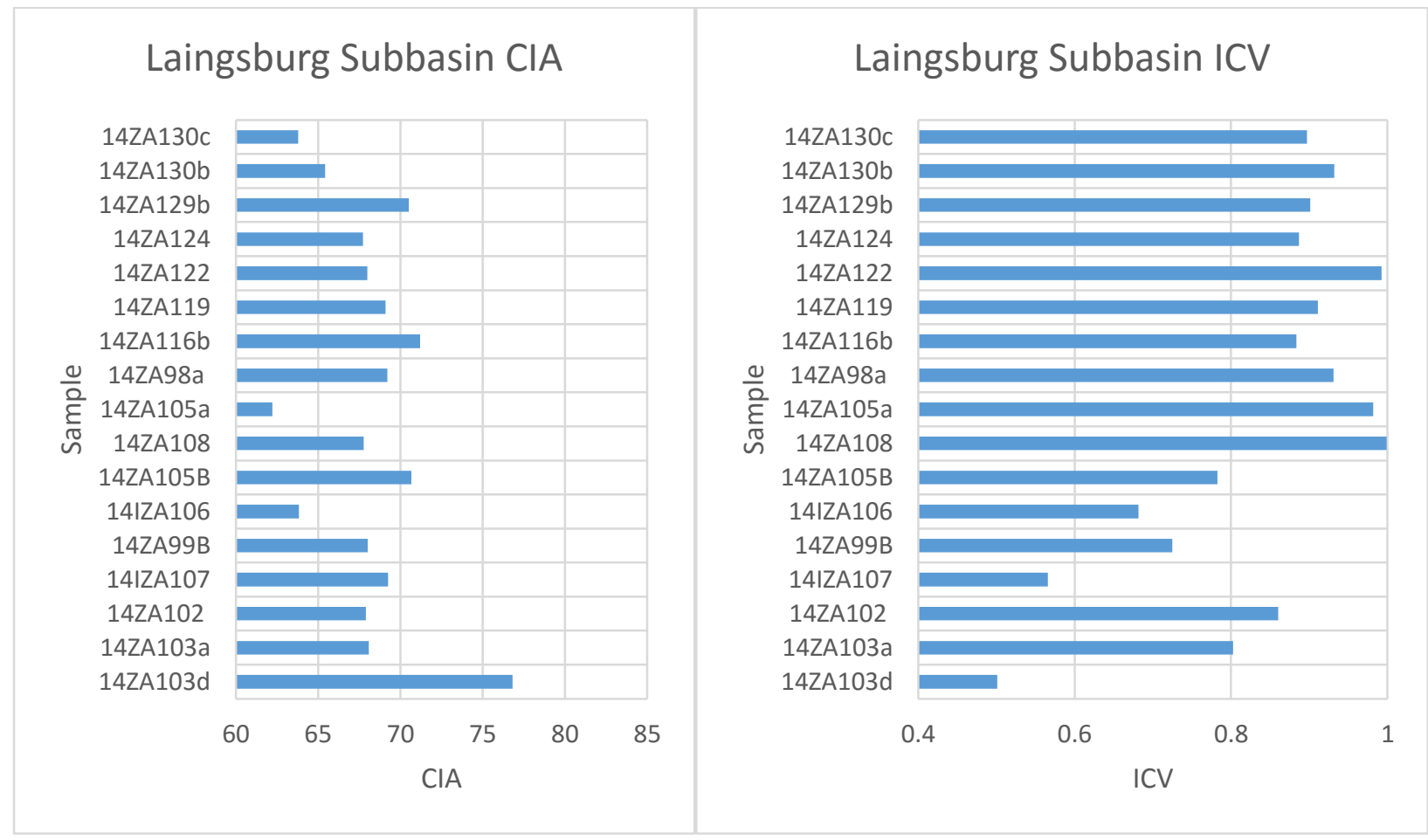

Figure 13: CIA and ICV values of the Laingsburg subbasin samples. CIA values decrease upsection. ICV values increase upsection.

\subsubsection{Ripon Subbasin}

Major elements in the Ripon subbasin are similar to those in the Laingsburg subbasin. $\mathrm{SiO}_{2}$ content varies in the Ripon subbasin from $90.7 \%$ (Whitehill Formation) to $60.8 \%$ (Ripon Formation). $\mathrm{SiO}_{2}$ averaged $65.6 \%(\mathrm{~s}=6.5 \%)$ is fairly close to the North American Shale Consortium average for $\mathrm{SiO}_{2}(64.8 \%)$ (Gromet et al., 1984), but many samples are enriched in $\mathrm{SiO}_{2}$ with respect to the NASC average. The rest of the major element contents are only slightly above NASC measurements, except for $\mathrm{MgO}$ (average $=1.7 \% ; \mathrm{s}=0.45)$ and $\mathrm{CaO}(0.7 \% ; \mathrm{s}=0.54)$ which are significantly below the averages for those elements (2.85\% and $3.56 \%$, respectively) (Gromet et al., 1984). 


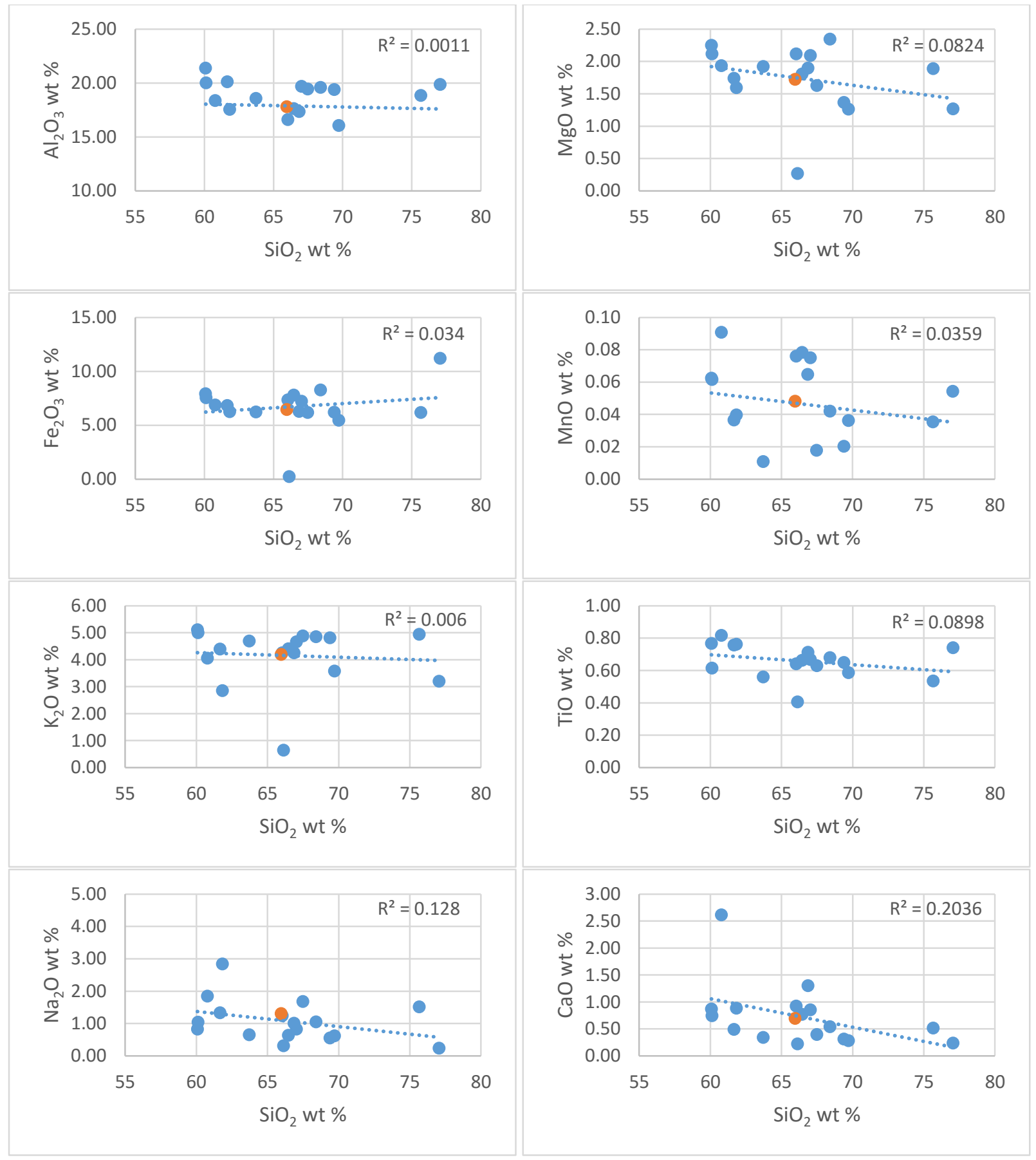

Figure 14: Plots of major elements from samples of the Ripon Subbasin (Blue) and NASC averages (Orange; data from Gromet et al., 1984).

CIA values decrease slightly upsection, and averages $70(s=4.6)$ (Figure 15). The majority of samples have low to moderate values $(66-75)$ but the Prince Albert is 82.2 and the upper Waterford sample is 60. ICV values averaged $0.85(\mathrm{~s}=0.09)$. ICV increases slowly from 
the Whitehill Formation up to the Waterford Formation $(0.6-0.9)$ and then remains high above the base of the Waterford Formation ( 0.9).

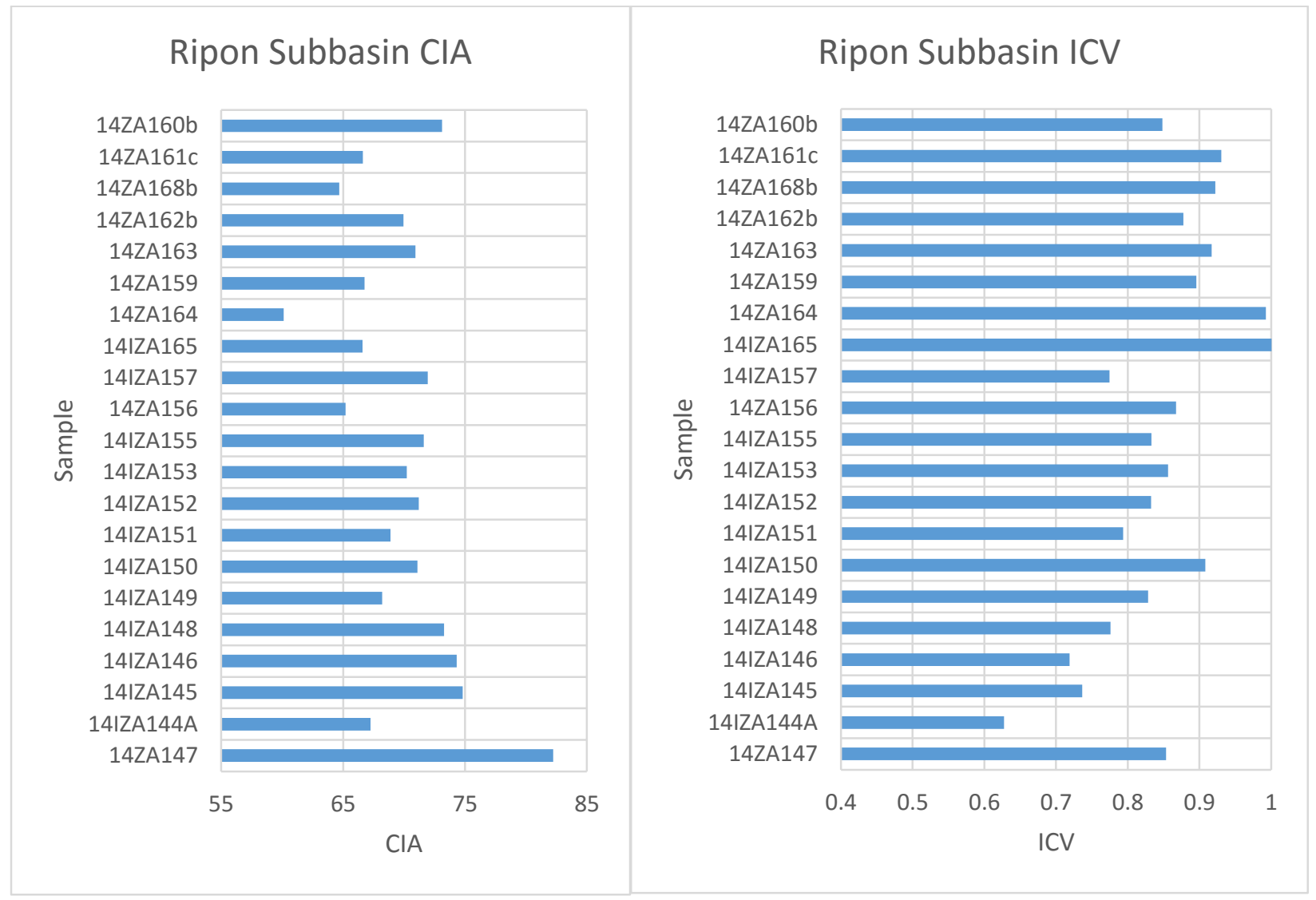

Figure 15: CIA and ICV values of the Ripon subbasin samples. CIA decreases upsection, and ICV increases upsection.

\subsubsection{Comparison of Major Element Composition}

A plot of CIA versus albite weight percentage shows that high albite weight percentage correlates with low CIA (Figure 16). The sodium ( $\mathrm{Na}$ ) in albite should influence both weathering indices, but shows no correlation $\left(\mathrm{R}^{2}=0.05\right)$ with ICV. This weak correlation with ICV is probably due to Na content being a smaller portion of the total element content used to calculate ICV than to calculate CIA. The aluminum (Al) in muscovite and illite should also influence weathering indices, but show no correlation. High quartz weight percentage correlates with low ICV, but not with CIA. 


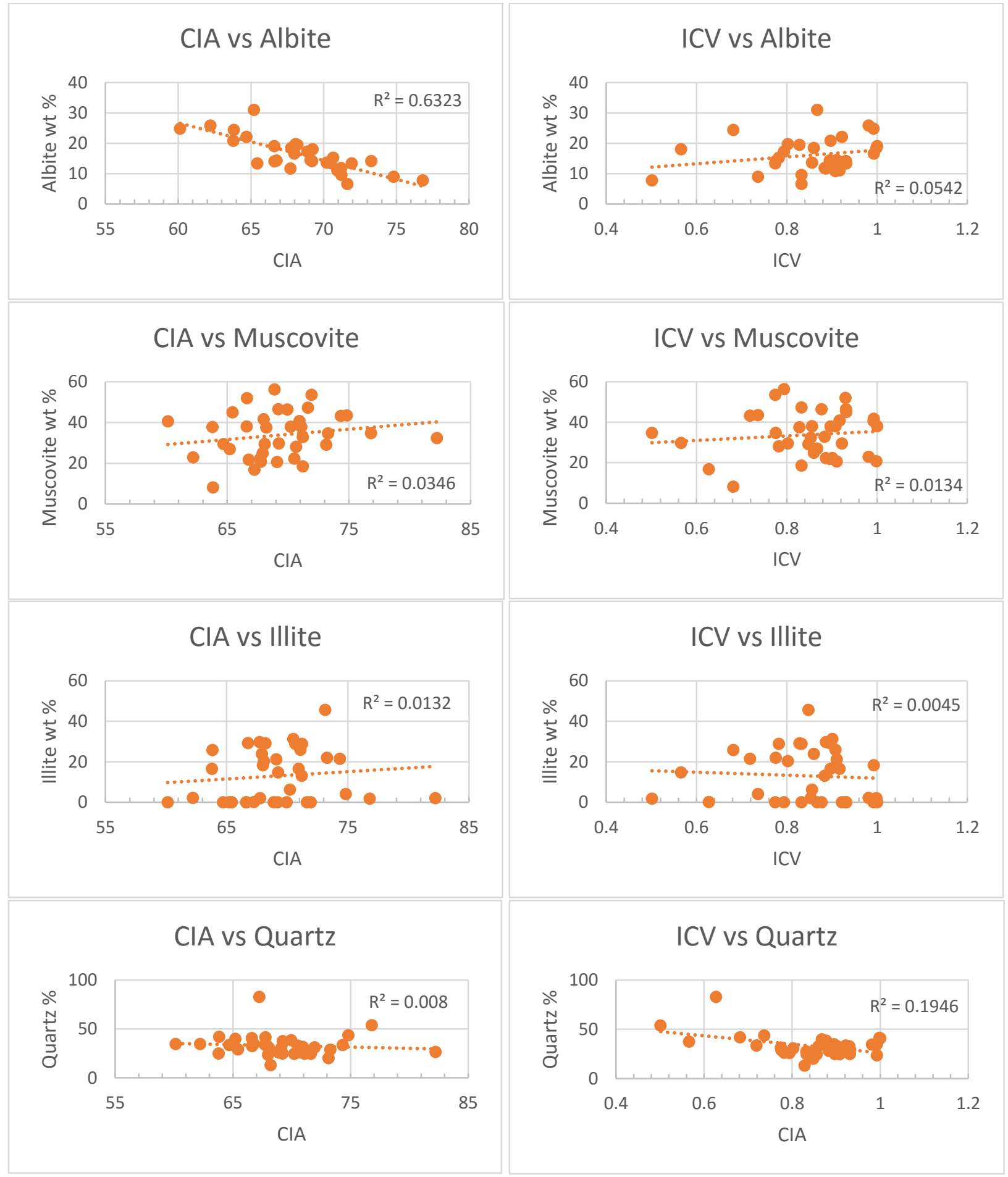

Figure 16: Plots of CIA and ICV against various mineral weight percentage in all samples from both subbasins show a correlation between CIA and albite weight percentage $\left(R^{2}=0.63\right)$ and a weak correlation between ICV and quartz weight percentage $\left(R^{2}=0.19\right)$, but not between any other weathering index with mineral weight percentage.

On the A-CN-K diagram, the samples of this study plot between the average upper crust and granite trends near where average shale plots (Figure 17) (McLennan et al, 1993; Fedo et al., 1995). A crossplot of potassium oxide content and CIA shows that potassium content does not 
co-vary with CIA, indicating potassium metasomatism did not occur in these rocks (Figure 18; Nesbitt and Young, 1989; McLennan et al., 1993; Fedo et al., 1995). High muscovite content correlates with high potassium content, indicating muscovite is a control on potassium in the samples (Figure 18).

$\mathrm{TiO}_{2}$ is characteristic of mafic minerals such as biotite, amphibole, pyroxene, and olivine (nesbitt, 1979; Taylor and McLennan, 1985). These minerals weather easily to clay minerals, but the clay retains the $\mathrm{TiO}_{2}$. A ratio of $\mathrm{TiO}_{2}$ to $\mathrm{Al}_{2} \mathrm{O}_{3}$ shows the enrichment of $\mathrm{TiO}_{2}$, and therefore mafic component of the source rock (Andersson, 2004). The ratio increases upsection, especially in the Ripon Subbasin (Figure 19).
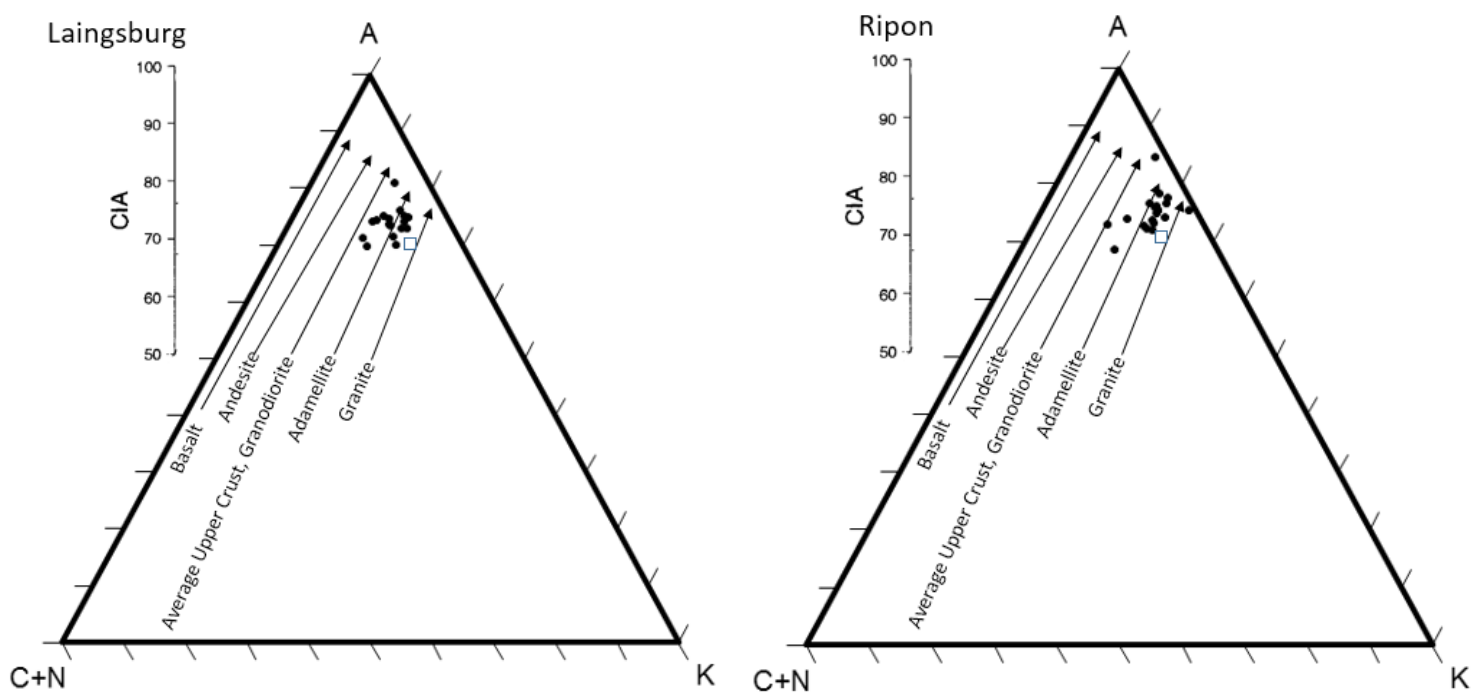

Figure 17: The A-CN-K diagram; weathering trends for basalt, andesite, average upper Archean upper crust, granodiorite, adamellite, and granite are shown, as well as the small square representing average Paleoproterozoic cratonic shale, and small dots representing the samples of this study (Modified after Nesbitt and Young, 1989; McLennan et al., 1990; Fedo et al., 1995).

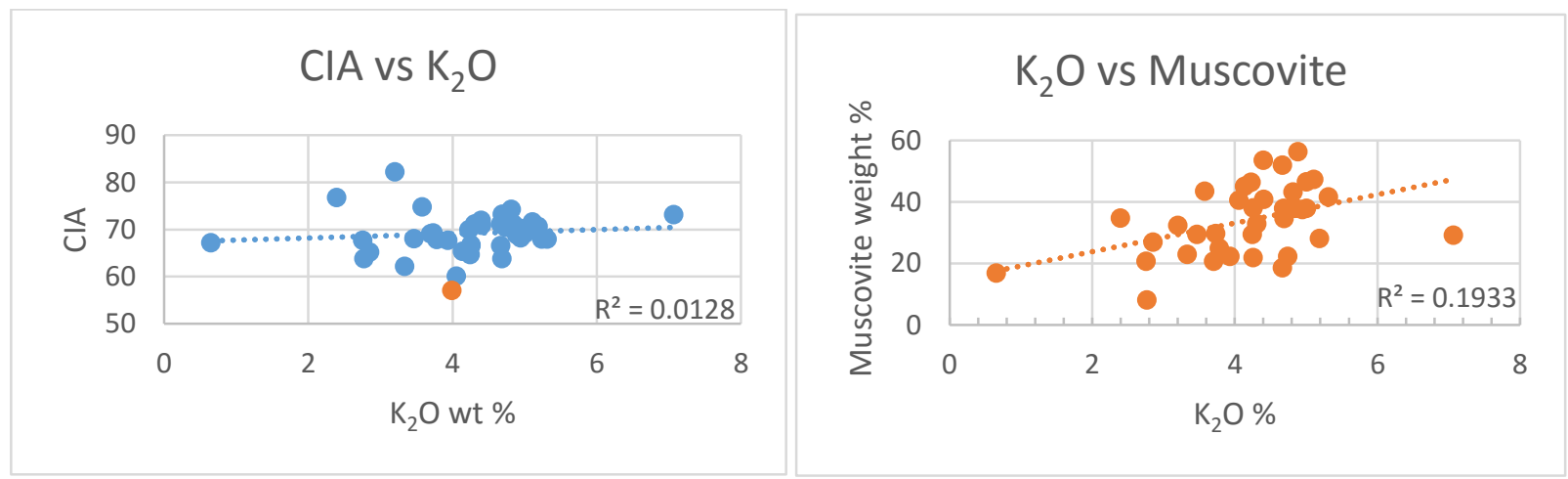

Figure 18: A plot of CIA versus potassium shows no correlation. Data from both subbasins (blue) and NASC (orange) values are plotted. A plot of $\mathrm{K}_{2} \mathrm{O}$ versus muscovite weight percentage shows a correlation between high muscovite content and high $\mathrm{K}_{2} \mathrm{O}$ content. 


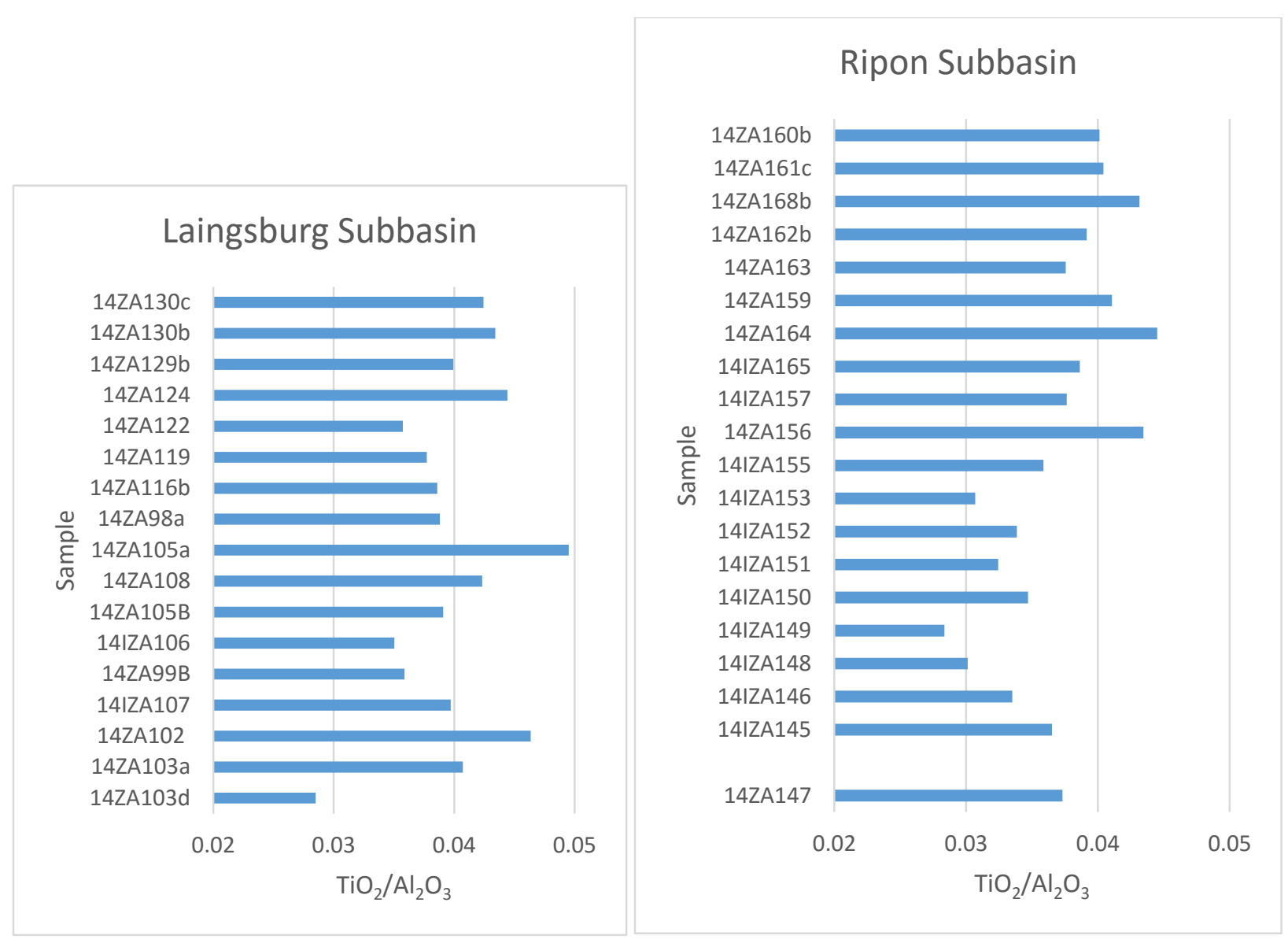

Figure 19: $\mathrm{TiO}_{2} / \mathrm{Al}_{2} \mathrm{O}_{3}$ is an indicator of source rock composition. Higher values upsection indicate more mafic sediment upsection, especially in the Ripon Subbasin.

\subsection{Trace Element Results}

Trace elements in samples from both basins are similar (Appendix III). Multi-element spider diagram patterns are similar to those from active continental margin basalts that, in comparison with MORB, are enriched in incompatible elements $\mathrm{Rb}, \mathrm{Ba}, \mathrm{Th}, \mathrm{La}, \mathrm{Ce}, \mathrm{Sm}, \mathrm{Ta}, \mathrm{Nb}$, $\mathrm{Zr}$, and Hf (Figure 20) (Pearce, 1983). Samples from both the Ripon and Laingsburg subbasins have a mix of Th/U values greater and less than 4, which is the boundary between crustal and arc sources (Figure 21; McLennan et al., 1993). Several samples of the Prince Albert, Whitehill, Collingham, and lower Laingsburg formations in the Laingsburg subbasin have a Th/U ratio less than 4, indicating a crustal source. The same is seen in the Ripon subbasin, where several samples of the Whitehill, Collingham, and Ripon formations have a Th/U ratio less than 4 . Th/Sc values range from 0.9 to 1.41 , and $\mathrm{Zr} / \mathrm{Sc}$ values range from 6.0 to 16.8 (Figure 22). These values are slightly elevated compared to active margin sediments that have a young, fresh igneous source. A crossplot of CIA versus Th/U shows nor correlation and indicates major elements do not change at the same rate as U during weathering (Figure 23). 


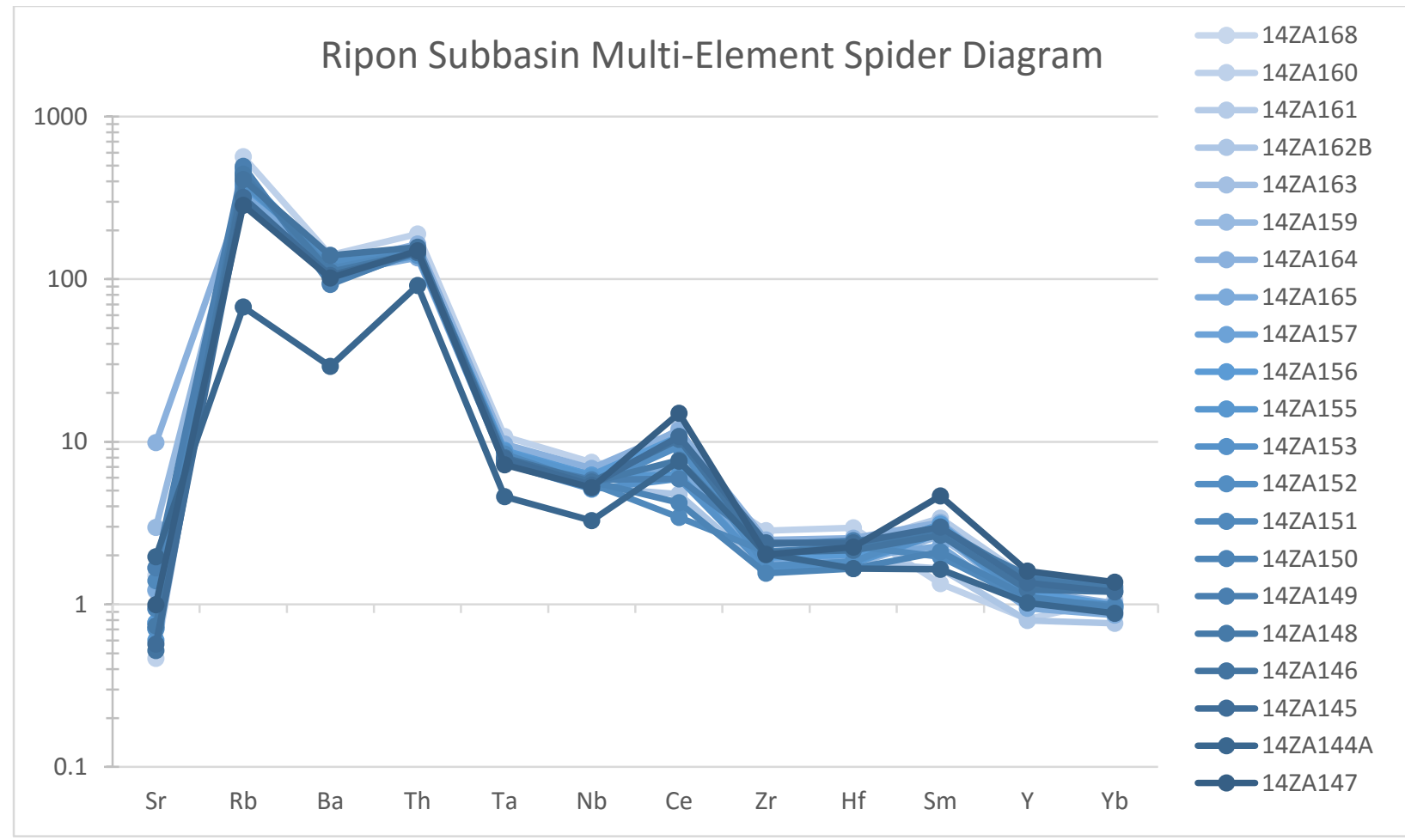

Figure 20: Multi-element diagrams of trace elements from the Ripon (A) and Laingsburg (B) subbasins showing an active continental margin arc signature (Pearce, 1983).

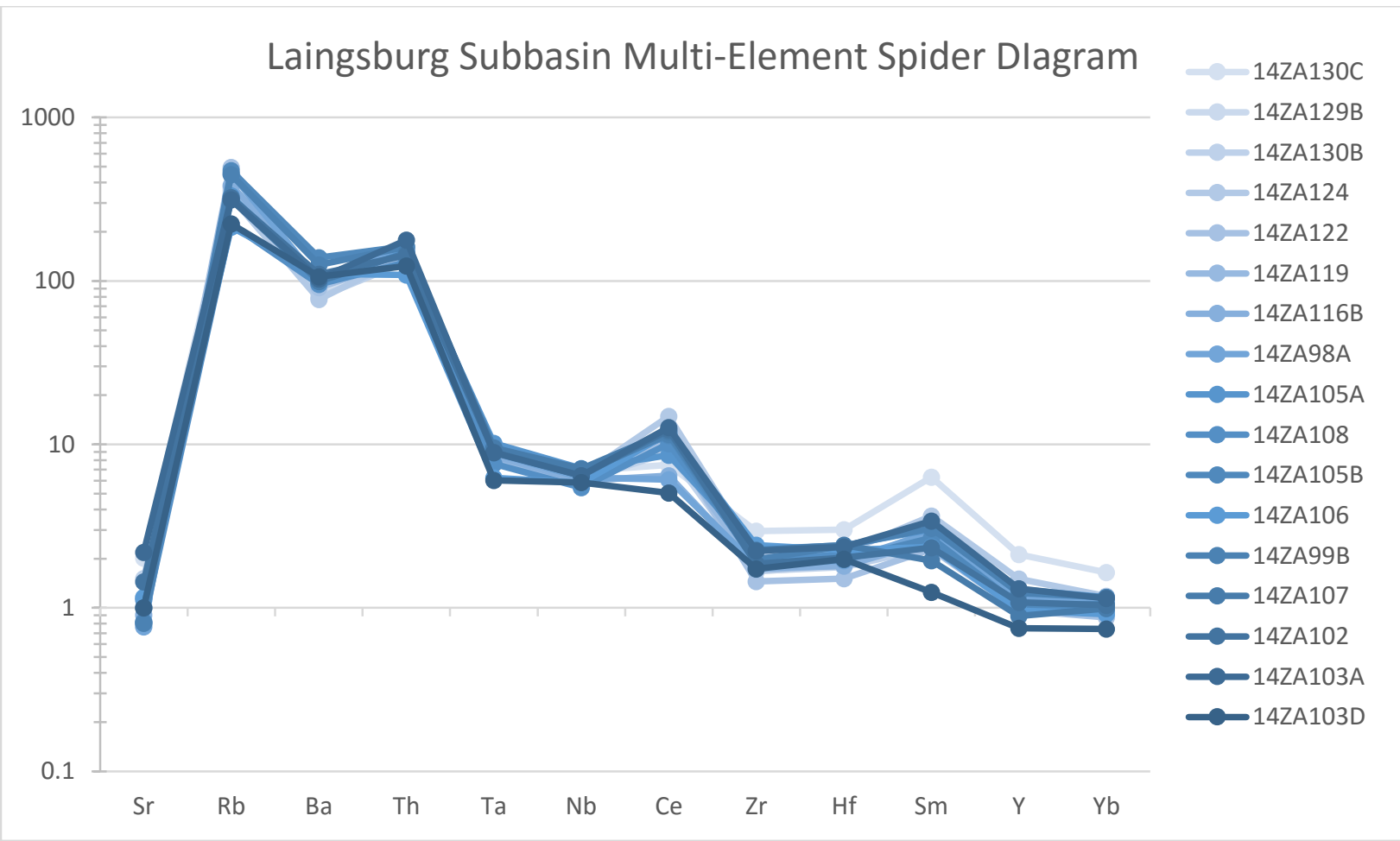



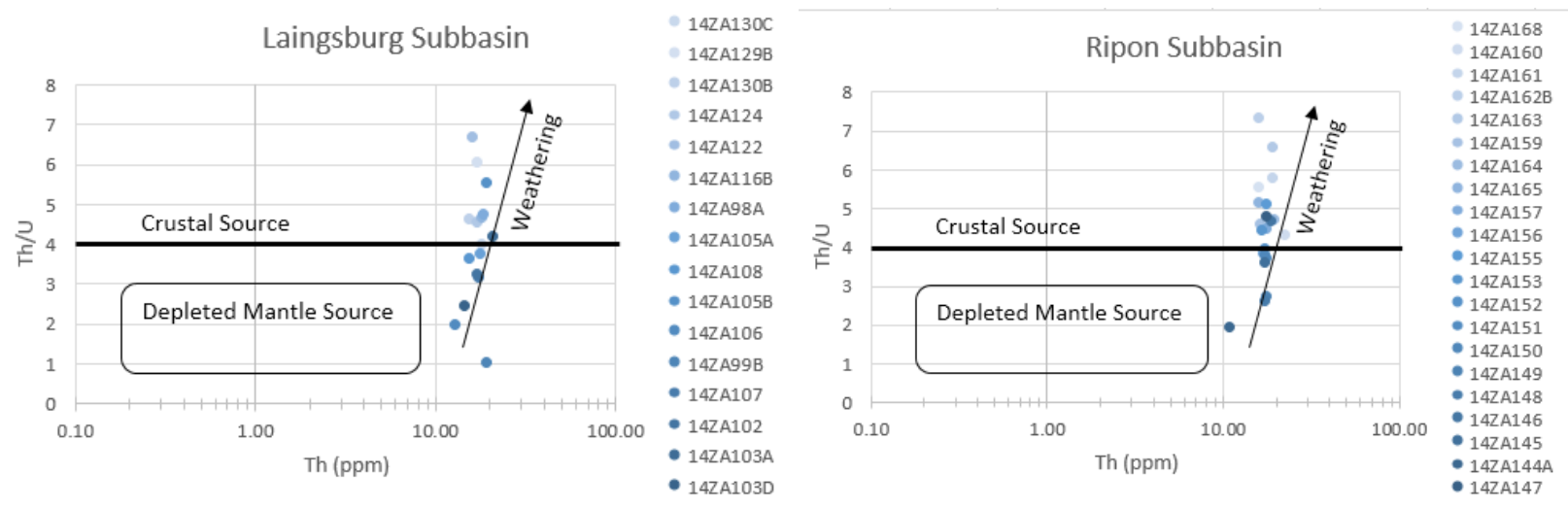

Figure 21: Cross-plots of Th/U versus Th show that samples have a wide range of Th/U ratio values that increase upsection. $A$ Th/U value greater than 4 indicates a crustal source that has undergone weathering (Modified after McLennan et al., 1993).
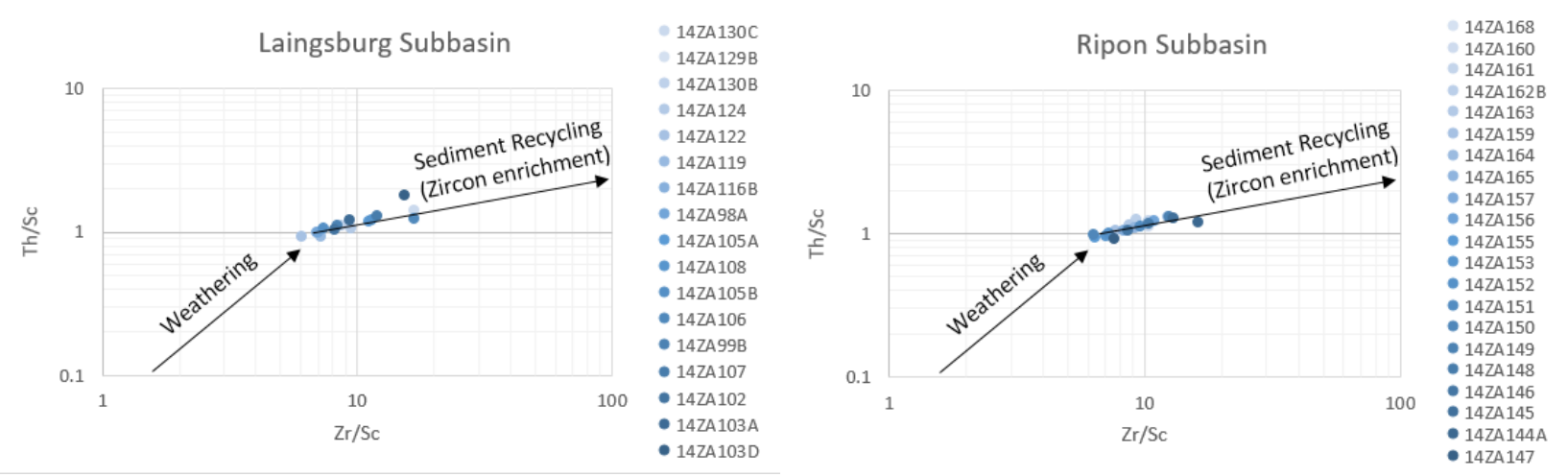

Figure 22: Crossplots of Th/Sc versus Zr/Sc showing Zr and Th enrichment in samples of both subbasins (Modified after McLennan et al., 1993).

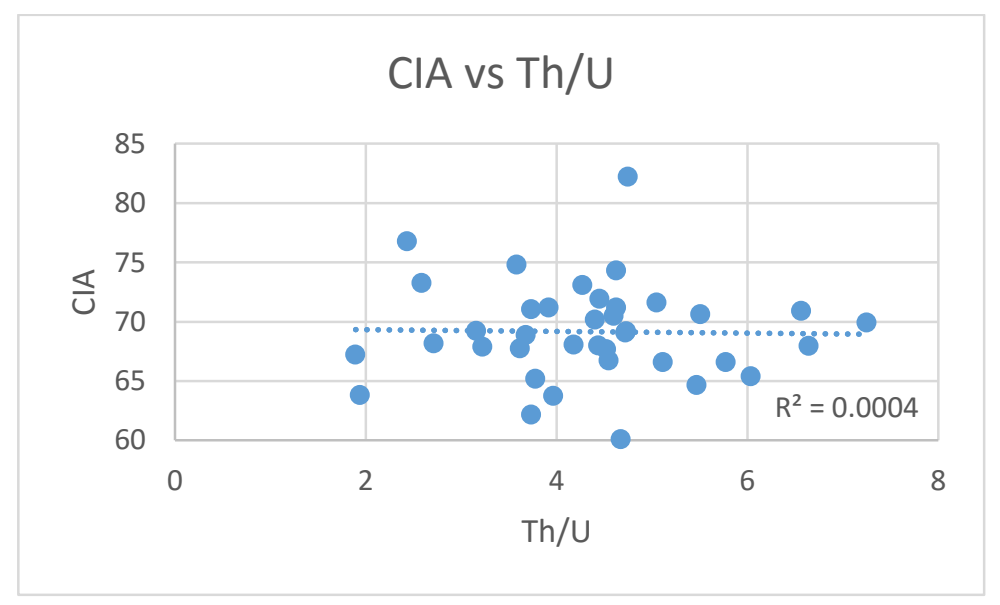

Figure 23: A crossplot of CIA versus Th/U shows nor correlation and indicates major elements do not change at the same rate as $U$ during weathering.

\subsection{Rare Earth Element Results}

All samples are characterized by negative Eu anomalies (Eu/Eu*: $0.46-0.69)$ and moderate to high chondrite-normalized light rare earth element (LREE) enrichment, from 196 581(Appendix III). In the Ripon subbasin, sample 14ZA147 of the Prince Albert Formation has the greatest LREE enrichment of 291.9 ppm, while samples 14ZA150 and 14ZA151 of the Ripon 
Formation and 14ZA162B of the Balfour Formation have the lowest LREE enrichment of 94.4, 81.9, and 95.2, respectively (Figure 24; Table 3). Samples 14ZA149, 14ZA150, 14ZA151, 14ZA152, 14ZA153, 14ZA155, and 14ZA156 from the Ripon Fm., 14ZA165 from the Waterford Fm., and 14ZA162 and 14ZA160 from the Balfour Fm. have a negative Ce anomaly. In the Laingsburg subbasin, samples 14ZA98A from the Laingsburg Fm., 14ZA122 from the base of the Waterford Fm., and 14ZA130C from the Abrahamskral Fm. have a negative Ce anomaly. In the Laingsburg subbasin, samples 14ZA124 of the Waterford Formation 14ZA130C of the Balfour Formation have the greatest LREE content of 265.9 and 259.9, respectively, while sample 14ZA103D of the Prince Albert Formation has the lowest LREE content of 85.8 (Figure 25; Table 3). In the Ripon subbasin high $\Sigma$ REE correlates with low CIA, but in the Laingsburg subbasin high $\Sigma$ REE correlates with high CIA (Figures 26 and 27). In the Laingsburg subbasin, $\Sigma$ REE correlates poorly with quartz and albite, but not in the Ripon subbasin (Figures 28 and 29).

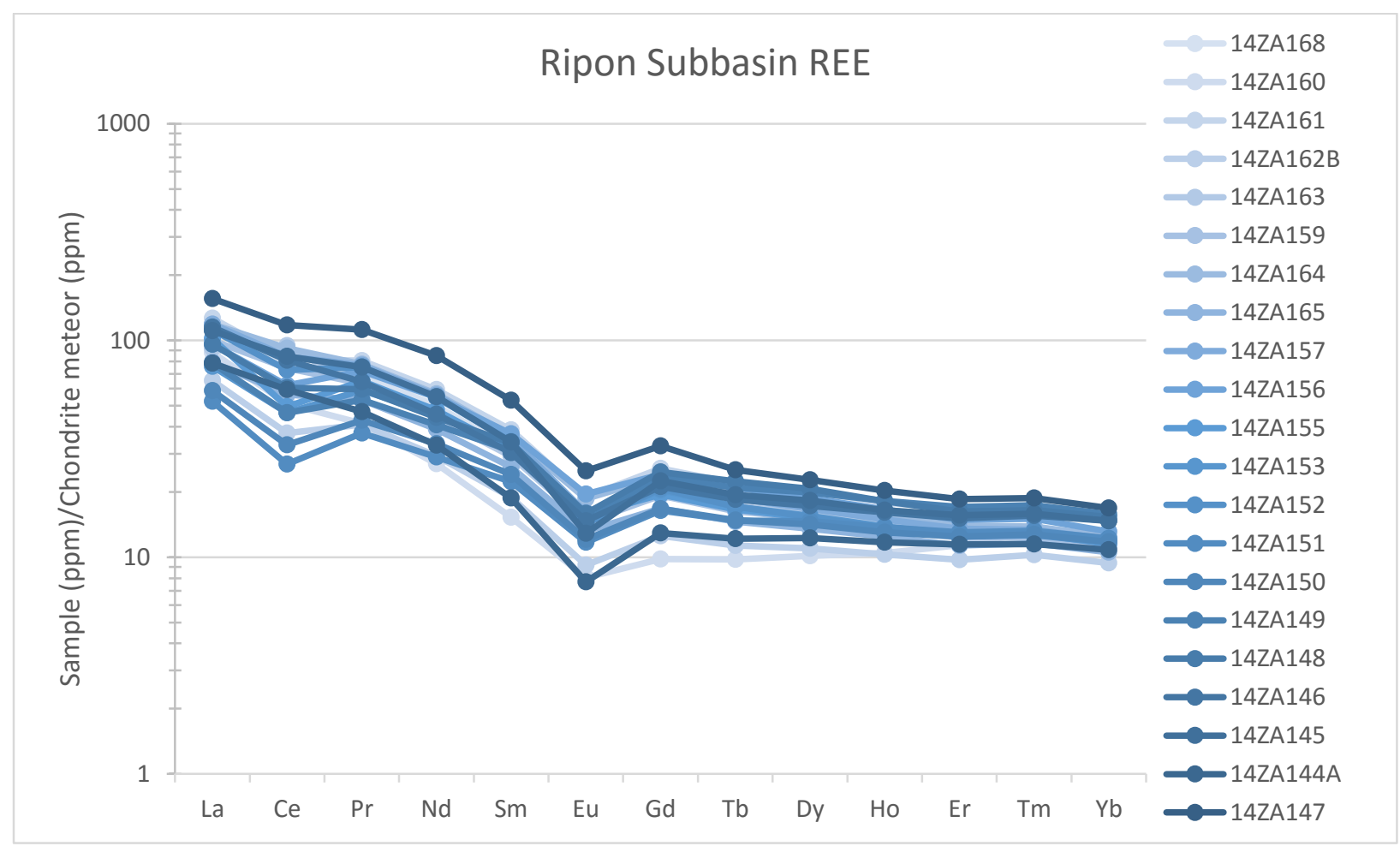

Figure 24: REE profiles from the Ripon subbasin. All samples have LREE enrichment, negative Eu anomaly, and HREE depletion. Samples 14ZA149, 14ZA150, 14ZA151, 14ZA152, 14ZA153, 14ZA155, and 14ZA156 from the Ripon Fm., $14 Z A 165$ from the Waterford Fm., and 14ZA162 and 14ZA160 from the Balfour Fm. have a negative Ce anomaly. 


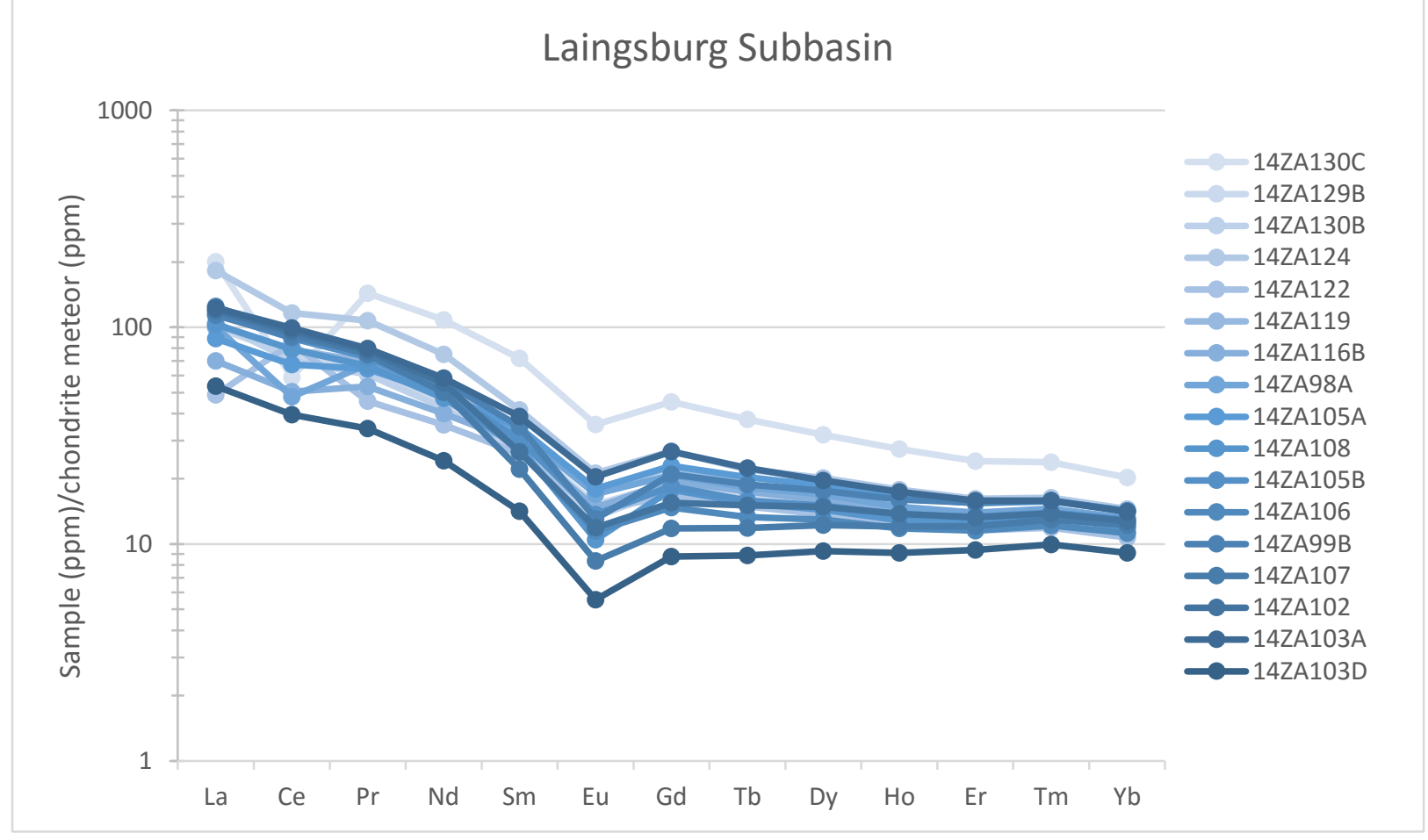

Figure 25: REE profiles from the Laingsburg subbasin. All samples have LREE enrichment, negative Eu anomaly, and HREE depletion. 14ZA98A from the Laingsburg Fm., 14ZA122 from the base of the Waterford Fm., and 14ZA130C from the Abrahamskral Fm. have a negative Ce anomaly.

Table 3: Calculated REE data.

\begin{tabular}{|c|c|c|c|c|c|c|c|c|}
\hline Sample ID & Subbasin & Formation & इREE & LLREE & इHREE & 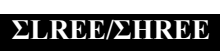 & $\mathbf{E u} / \mathbf{E u} *$ & $\mathrm{Ce} / \mathrm{Ce}^{*}$ \\
\hline 14ZA147 & Ripon & Prince Albert & 291.861 & 269.916 & 21.945 & 12.299 & 0.171 & 0.784 \\
\hline 14ZA144A & Ripon & Whitehill & 137.093 & 124.355 & 12.738 & 9.762 & 0.057 & 3.792 \\
\hline 14ZA145 & Ripon & Collingham & 204.916 & 186.754 & 18.162 & 10.282 & 0.144 & 0.201 \\
\hline 14ZA146 & Ripon & Collingham & 193.186 & 175.631 & 17.556 & 10.004 & 0.211 & 0.207 \\
\hline 14ZA148 & Ripon & Ripon & 168.920 & 149.173 & 19.747 & 7.554 & 0.147 & 0.331 \\
\hline 14ZA149 & Ripon & Ripon & 144.741 & 124.973 & 19.767 & 6.322 & 0.086 & 0.532 \\
\hline 14ZA150 & Ripon & Ripon & 108.648 & 94.371 & 14.277 & 6.610 & 0.185 & 0.605 \\
\hline 14ZA151 & Ripon & Ripon & 96.677 & 81.870 & 14.806 & 5.529 & 0.115 & 0.666 \\
\hline 14ZA152 & Ripon & Ripon & 190.520 & 175.635 & 14.885 & 11.800 & 0.194 & 0.450 \\
\hline 14ZA153 & Ripon & Ripon & 142.566 & 127.396 & 15.170 & 8.398 & 0.199 & 0.395 \\
\hline 14ZA155 & Ripon & Ripon & 156.697 & 141.946 & 14.751 & 9.623 & 0.234 & 0.361 \\
\hline 14ZA156 & Ripon & Ripon & 178.554 & 160.797 & 17.757 & 9.055 & 0.099 & 1.560 \\
\hline 14ZA157 & Ripon & Fort Brown & 206.908 & 190.868 & 16.039 & 11.900 & 0.173 & 0.526 \\
\hline 14ZA165 & Ripon & Waterford & 143.464 & 130.156 & 13.308 & 9.781 & 0.121 & 0.861 \\
\hline 14ZA164 & Ripon & Waterford & 216.439 & 199.825 & 16.614 & 12.028 & 0.037 & 6.269 \\
\hline 14ZA159 & Ripon & Koonap & 177.886 & 163.363 & 14.523 & 11.248 & 0.088 & 1.803 \\
\hline 14ZA163 & Ripon & Koonap & 193.515 & 177.909 & 15.606 & 11.400 & 0.151 & 0.416 \\
\hline 14ZA162B & Ripon & Balfour & 106.366 & 95.176 & 11.190 & 8.505 & 0.114 & 0.438 \\
\hline 14ZA161 & Ripon & Balfour & 216.180 & 196.643 & 19.537 & 10.065 & 0.101 & 0.735 \\
\hline 14ZA160 & Ripon & Balfour & 125.589 & 113.183 & 12.406 & 9.123 & 0.216 & 0.190 \\
\hline
\end{tabular}




\begin{tabular}{|c|c|c|c|c|c|c|c|c|}
\hline 14ZA168 & Ripon & Balfour & 189.830 & 175.178 & 14.652 & 11.956 & 0.113 & 1.078 \\
\hline Average & Ripon & & 170.979 & 155.006 & 15.973 & 9.678 & 0.141 & 1.057 \\
\hline $\begin{array}{l}\text { Standard } \\
\text { Deviation }\end{array}$ & Ripon & & 44.859 & 43.043 & 2.696 & 1.942 & 0.053 & 1.404 \\
\hline 14ZA103D & Laingsburg & Prince Albert & 95.986 & 85.846 & 10.141 & 8.465 & 0.077 & 0.652 \\
\hline 14ZA103A & Laingsburg & Prince Albert & 230.209 & 211.373 & 18.836 & 11.222 & 0.098 & 1.472 \\
\hline 14ZA102 & Laingsburg & Whitehill & 213.663 & 198.488 & 15.175 & 13.080 & 0.126 & 1.134 \\
\hline 14ZA107 & Laingsburg & Whitehill & 202.099 & 188.734 & 13.365 & 14.121 & 0.114 & 0.726 \\
\hline 14ZA99B & Laingsburg & Collingham & 212.006 & 194.298 & 17.708 & 10.972 & 0.171 & 0.405 \\
\hline 14ZA106 & Laingsburg & Collingham & 205.847 & 192.607 & 13.240 & 14.547 & 0.078 & 1.127 \\
\hline 14ZA105B & Laingsburg & Vischkuil & 202.620 & 187.250 & 15.370 & 12.183 & 0.185 & 0.384 \\
\hline 14ZA108 & Laingsburg & Laingsburg & 183.662 & 169.130 & 14.532 & 11.638 & 0.123 & 0.860 \\
\hline 14ZA105A & Laingsburg & Laingsburg & 175.213 & 157.076 & 18.136 & 8.661 & 0.117 & 0.717 \\
\hline 14ZA98A & Laingsburg & Laingsburg & 158.850 & 142.317 & 16.532 & 8.608 & 0.198 & 0.362 \\
\hline 14ZA116B & Laingsburg & Laingsburg & 139.449 & 123.750 & 15.699 & 7.883 & 0.181 & 0.547 \\
\hline 14ZA119 & Laingsburg & Laingsburg & 191.524 & 175.347 & 16.177 & 10.839 & 0.154 & 0.859 \\
\hline 14ZA122 & Laingsburg & Waterford & 156.032 & 142.526 & 13.506 & 10.553 & 0.180 & 0.394 \\
\hline 14ZA124 & Laingsburg & Waterford & 285.162 & 265.911 & 19.251 & 13.813 & 0.154 & 0.563 \\
\hline 14ZA130B & Laingsburg & Abrahamskral & 171.987 & 157.389 & 14.598 & 10.782 & 0.111 & 0.999 \\
\hline 14ZA129B & Laingsburg & Abrahamskral & 178.417 & 164.105 & 14.312 & 11.466 & 0.183 & 0.460 \\
\hline 14ZA130C & Laingsburg & Abrahamskral & 289.135 & 259.854 & 29.282 & 8.874 & 0.065 & 1.059 \\
\hline Average & Laingsburg & & 193.639 & 177.412 & 16.227 & 11.042 & 0.136 & 0.748 \\
\hline $\begin{array}{l}\text { Standard } \\
\text { Deviation }\end{array}$ & Laingsburg & & 47.509 & 44.542 & 4.071 & 2.072 & 0.042 & 0.325 \\
\hline
\end{tabular}




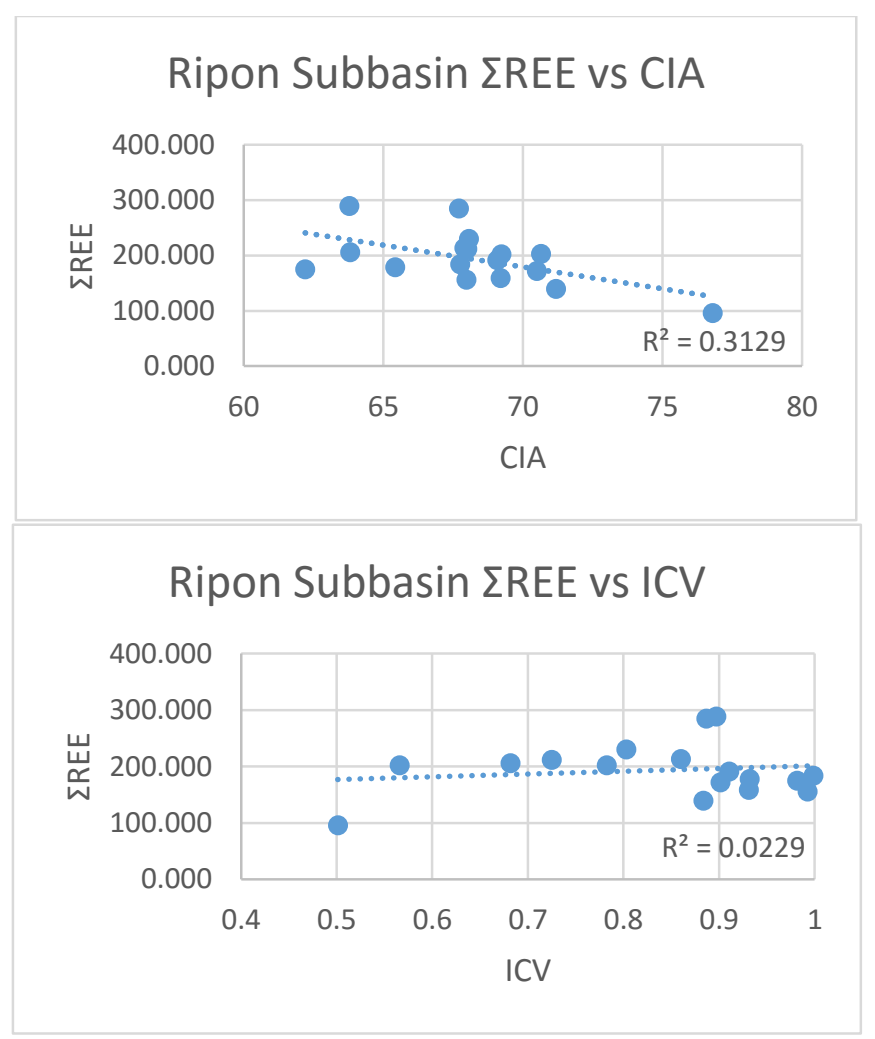

Figure 26: In the Ripon subbasin, $\Sigma R E E$ versus CIA and ICV show weak $\left(R^{2}=0.31\right)$ and no correlation (0.02), respectively.

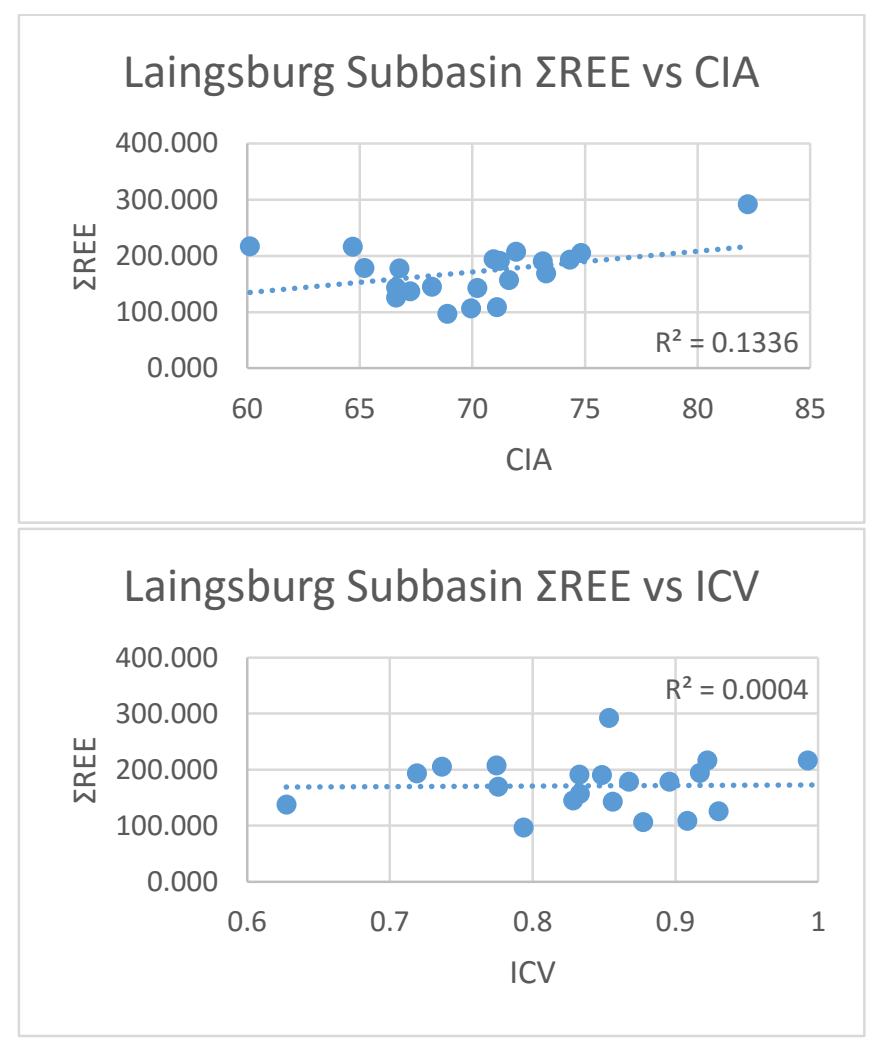

Figure 27: $\Sigma R E E$ versus CIA and ICV show weak $\left(R^{2}=0.13\right)$ and no correlation $\left(R^{2}=0.00\right)$, respectively in the Laingsburg subbasin. 


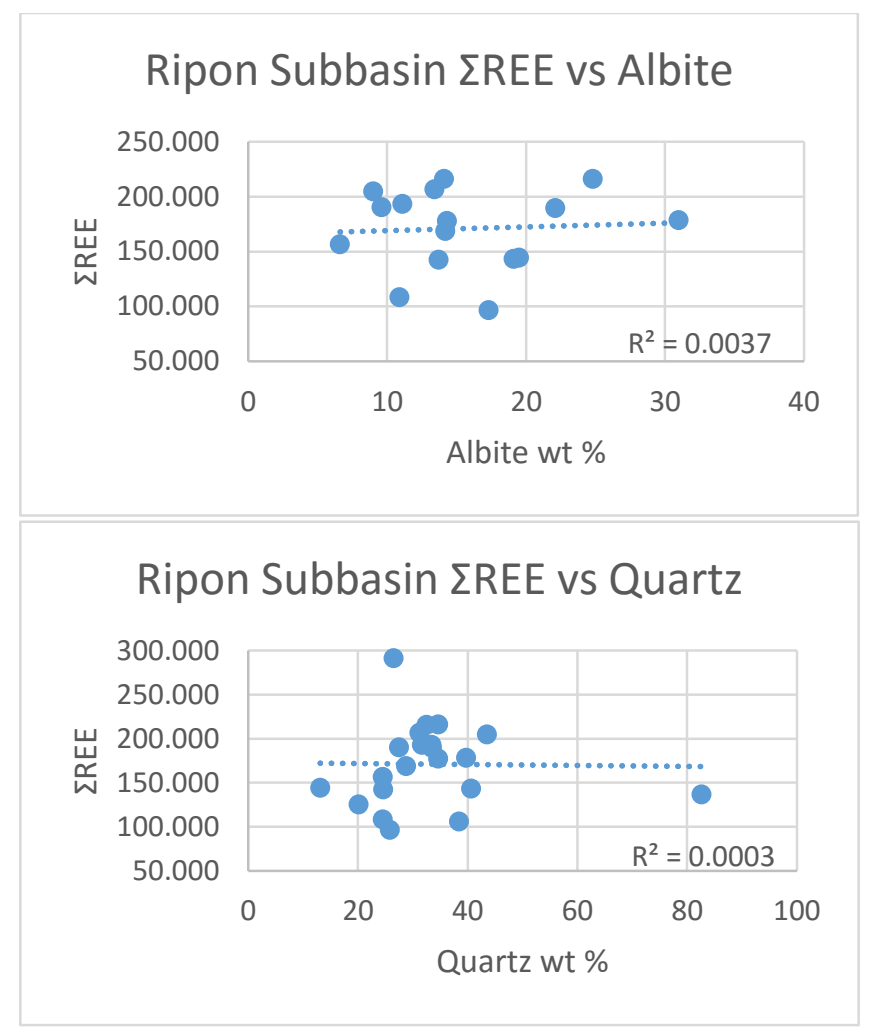

Figure 28: In the Ripon subbasin, $\Sigma R E E$ versus albite and quartz weight \% show no correlation $\left(R^{2}=0.00\right.$ and 0.00 , respectively).

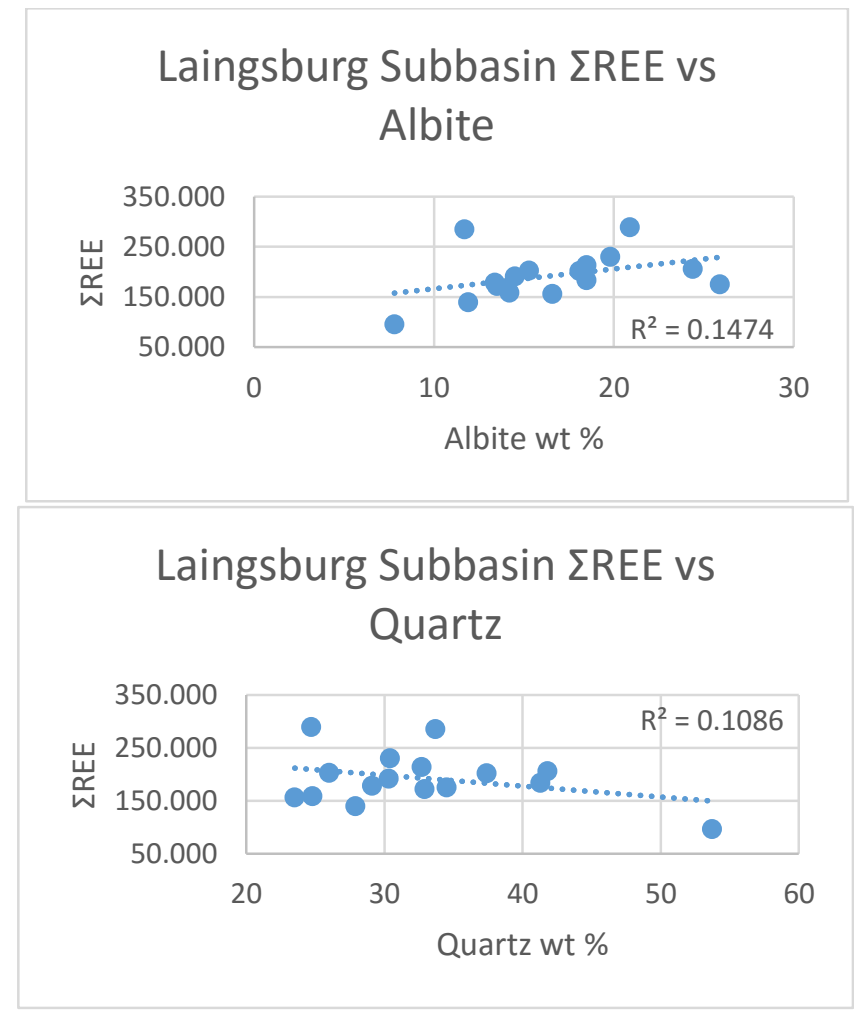

Figure 29: In the Ripon subbasin, $\Sigma R E E$ versus albite and quartz weight $\%$ show weak correlations $\left(R^{2}=0.11\right.$ and 0.15 , respectively). 


\subsection{Samarium and Neodymium Isotope Results}

Sm-Nd isotopic composition was determined for samples the Prince Albert, Whitehill, Collingham, Vischkuil and the base of the Ripon formations in the Laingsburg subbasin. These samples show that $\varepsilon N d$ values decrease from -6.07 in the Prince Albert Formation to -8.6 in the Vischkuil Formation and back up to -6.9 in the Laingsburg Formation reflecting oldest provenance in the Vischkuil Formation (Figure 29) (Appendix IV). The model age increases from $553 \mathrm{Ma}$ in the Prince Albert to $850 \mathrm{Ma}$ in the Laingsburg Formation, reflecting older provenance terranes upsection (Figure 31). A crossplot of $\Sigma$ REE versus $\varepsilon N d$ shows a correlation between high $\Sigma$ REE and a more negative $\varepsilon N d$ value (Figure 32). A crossplot of albite weight percentage versus $\varepsilon N d$ shows no correlation (Figure 32 ). A crossplot of albite versus $\mathrm{T}_{\mathrm{CHUR}}$ shows a weak correlation between high albite content and older model age (Figure 32). Crossplots of CIA versus $\varepsilon N d$ and $\mathrm{T}_{\text {CHUR }}$ show the opposite trend, because high albite content corresponds with low CIA (Figure 32).

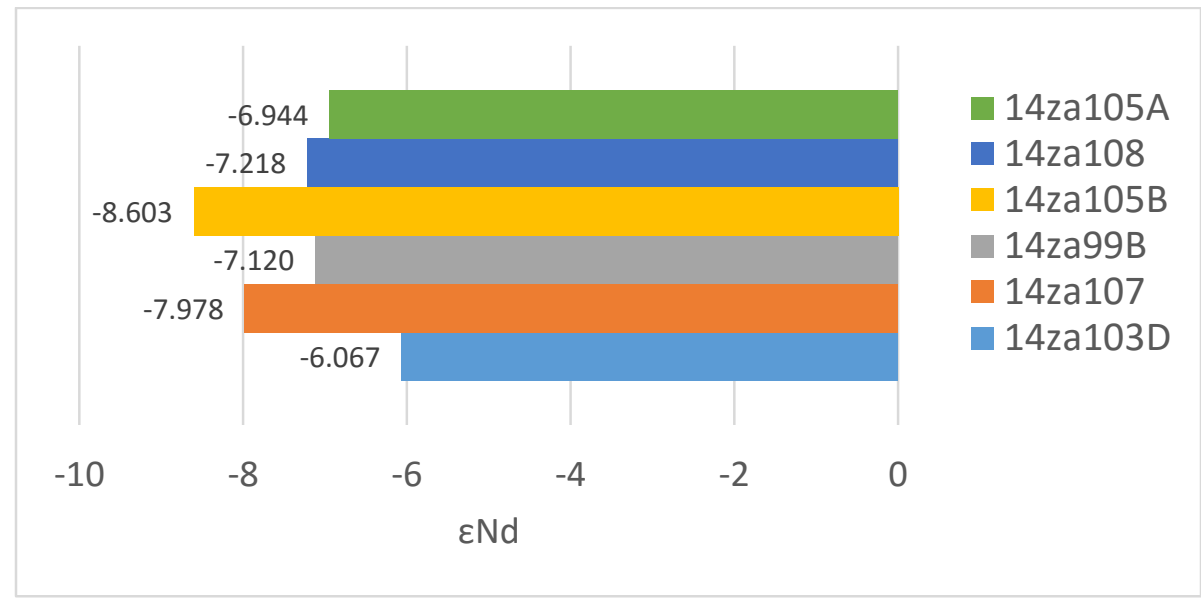

Figure 30: $\varepsilon N d$ becomes more negative upsection. Data from the lowermost and middle formations of the Ecca Group in the Laingsburg subbasin.

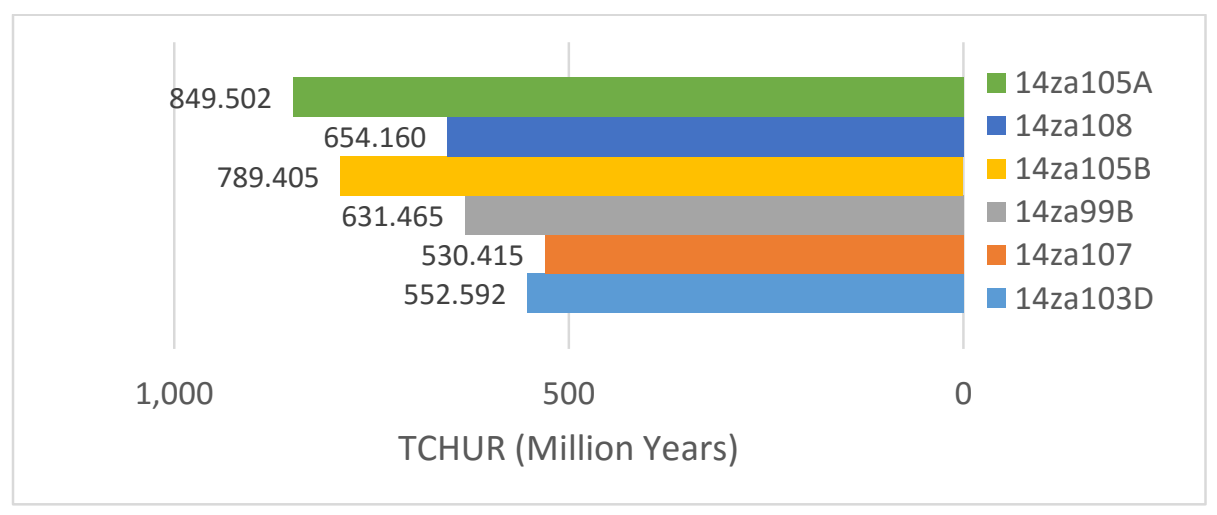

Figure 31: TCHUR increases upsection in the same samples as in the above $\varepsilon N d$ plot 


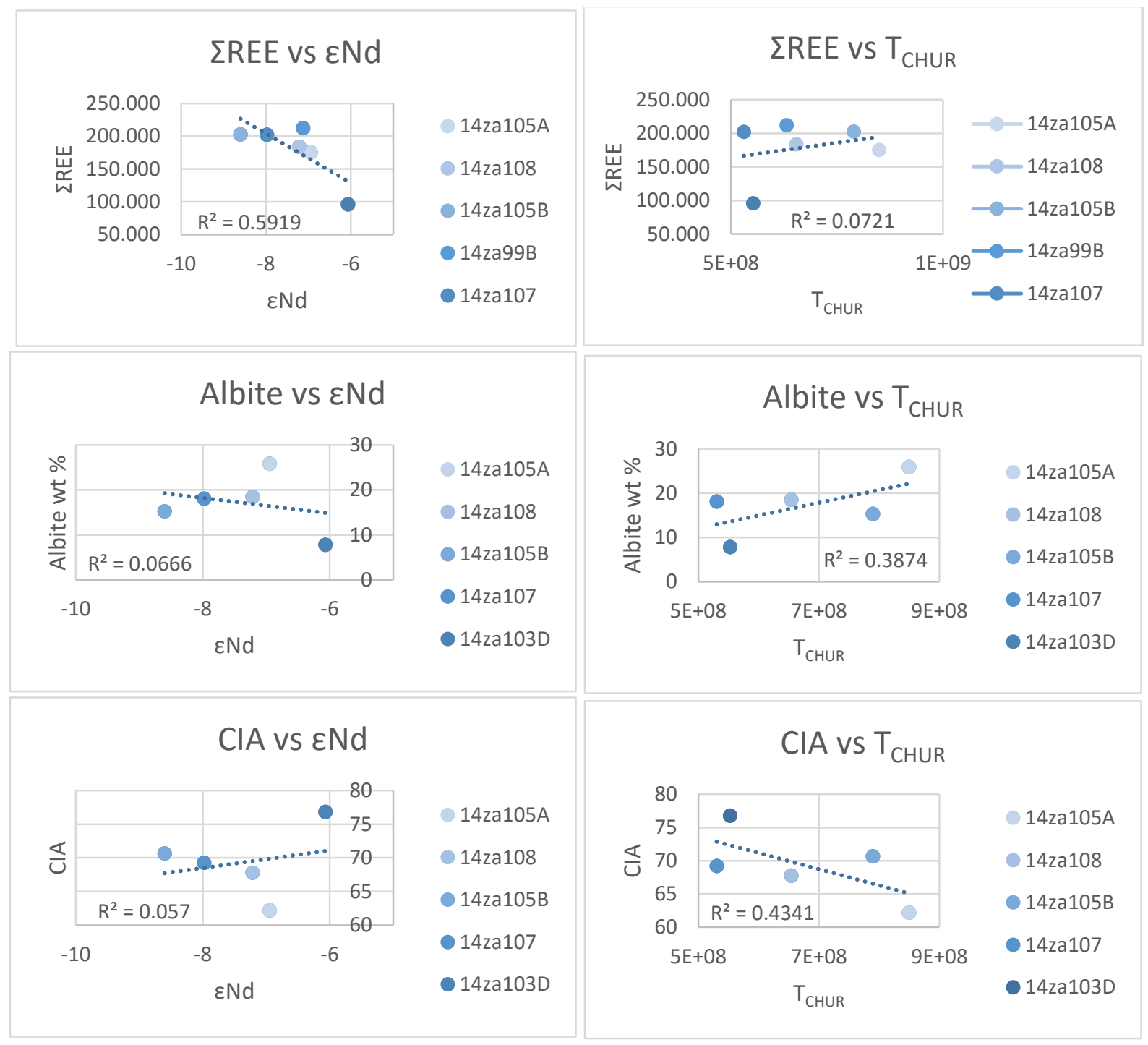

Figure 32: Sm-Nd data versus $\Sigma R E E$, albite, and CIA. A crossplot of $\Sigma R E E$ versus $E N d$ shows a correlation between high $\Sigma R E E$ and a more negative $\varepsilon N d$ value. A crossplot of albite weight percentage versus $\varepsilon N d$ shows no correlation. A crossplot of albite versus $T_{\text {CHUR }}$ shows a weak correlation between high albite content and older model age. Crossplots of CIA versus $\varepsilon N d$ and $T_{\text {CHUR }}$ show the opposite trend, because high albite content corresponds with low CIA.

\section{Chapter 4: Discussion}

\subsection{Provenance of mudstone units in the Ecca and Beaufort groups 4.1.1 Lithology and Composition of the source terranes}

Lithology of the source area can be determined through mineralogy, major elements, and isotopic data. Muscovite is ubiquitous in XRD results (average $=29.1 \mathrm{wt} \%$ ), and detrital muscovite is ubiquitous in thin-sections (average $=3.9 \%$ ) (Figures 6, 7, 8, 10, and 11). High muscovite weight percentages seen in XRD data are not seen in thin-section. This may be because most of the muscovite is diagenetic. Vitrinite reflectance values $\left(\mathrm{R}_{\mathrm{O}}\right)$ in the Whitehill Formation near the base of the Ecca Group average 4\% (Geel et al., 2015), which corresponds to a peak temperature of $\sim 300^{\circ} \mathrm{C}$ and an illite crystallinity Kubler Index value of 0.25 (Merriman and Kemp, 1996). At this temperature, smectite is altered to mixed-layer illite/smectite, illite, and 
muscovite (Merriman and Kemp, 1996). Most of the muscovite may have come from metamorphism. Detrital muscovite most commonly indicates a metamorphic source (Potter et al., 2005), but could also come from felsic igneous rocks or recycled sedimentary rocks. If the muscovite came from a metamorphic source, chlorite would also be expected in the samples. In the Laingsburg subbasin, chlorite is present in the Prince Albert, Vischkuil, Laingsburg formations, Waterford, and Abrahamskral formations, but not in the others (Figure 10). In the Ripon subbasin, chlorite is present in the Prince Albert, Ripon, Fort Brown, Waterford and Balfour formations (Figure 11). The absence of chlorite in the other formations could indicate that there was no metamorphic source during deposition of those formations. Muscovite could also be derived from felsic igneous rocks, such as rhyolite or granite. Other minerals in granite and rhyolite, such as feldspars and biotite, would weather to clay minerals while muscovite and quartz survived. Lastly, muscovite could be recycled from a sedimentary source, in which case only other stable minerals such as quartz and clay minerals would survive.

Quartz is also ubiquitous in XRD results, and there is a correlation between quartz and $\mathrm{SiO}_{2}$ content in the samples (Figures 10 and 11). The North American Shale Composite (NASC) contains on average $64.8 \% \mathrm{SiO}_{2}$ (Gromet et al., 1984). The average $\mathrm{SiO}_{2}$ content for samples of this study is $66 \%$. Samples of the Prince Albert, Whitehill, Collingham, Vischkuil and Waterford formations have high quartz content (>30\%) in the Laingsburg subbasin, and in the Ripon subbasin the Whitehill, Collingham, upper Ripon, Fort Brown, Waterford, Koonap, and Balfour formations have high quartz content $(>30 \%)$. As sediment is recycled, quartz, and therefore $\mathrm{SiO}_{2}$ content, will increase. However, petrography reveals that quartz in the samples is mostly microcrystalline quartz. Quartz can form authigenically from the diagenesis of silica derived from the dissolution of radiolarian or diatomic opal (Hesse, 1989; Schieber et al., 2000), dissolution of volcanic silica (Calvert, 1974), or from the release of silica during the alteration of smectite to illite (Peltonen et al., 2009). It is difficult to determine if most of the microcrystalline quartz is detrital or authigenic with a petrographic microscope (Figures 6, 7, 8, and 9). A scanning electron microscope study using backscattered and scanned cathodoluminescence imaging would need to be done to differentiate detrital from authigenic quartz with certainty (Schieber et al., 2000). If quartz in the samples is detrital, high quartz and $\mathrm{SiO}_{2}$ content could indicate recycling of a sedimentary source.

Albite is present in nearly all of the Ecca and Beaufort Group mudstone and could indicate the reworking of volcanic ash from the arc into the mudstone (Figures 10 and 11). The Ecca Group contains abundant thin beds of volcanic tuff from the Gondwanide Magmatic Arc (McKay et al., 2016). In order to determine if reworked ashes were incorporated into the mudstone, mineralogy was assessed to identify minerals specific to volcanic ashes. Volcanic ash is commonly altered to zeolite phases during diagenesis (Hay, 1986); however no zeolite phases were identified in XRD analysis. Because clay- and silt-sized feldspar minerals typically don't survive the chemical weathering process that occurs during transportation of sediment to the deposition of shale, the presence of plagioclase could indicate addition of volcanic ash from an andesitic arc, or growth of authigenic feldspar phases during diagenesis (Milliken, 1988, 1989, 2003; Potter et al., 2005). If albite were coming from the volcanic ash, one would expect to see $\varepsilon \mathrm{Nd}$ become less negative with high albite content and $\mathrm{T}_{\mathrm{CHUR}}$ decrease because zircon in the ash 
is Permian in age (Fildani et al., 2007; Fildani et al., 2009; McKay et al., 2015). A crossplot of albite versus $\mathrm{T}_{\text {CHUR }}$ shows a correlation between high albite content and older model age, and a crossplot of albite content versus $\varepsilon N d$ shows no correlation (Figure 32). The correlation between albite and $\mathrm{T}_{\mathrm{CHUR}}$ indicates that albite did not come from reworking of volcanic ash into the mudstone.

Composition of the source terranes can be determined with major elements, trace elements, REE, and mineralogy. The A-CN-K diagram indicates samples are following the weathering trends of felsic rocks (Figure 17). Differing weathering trends on the A-CN-K diagram are entirely dependent on the amount of $\mathrm{K}_{2} \mathrm{O}$ in the sample, because felsic rocks contain more potassium bearing minerals, such as muscovite and potassium-feldspar, than mafic rocks. $\mathrm{TiO}_{2}$ is present in mafic minerals, and is not removed during the alteration of these minerals to clay. A crossplot of $\mathrm{TiO}_{2} / \mathrm{Al}_{2} \mathrm{O}_{3}$ indicates more contribution from mafic sources upsection.

Trace elements $\mathrm{Rb}, \mathrm{Ba}, \mathrm{Th}, \mathrm{La}, \mathrm{Ce}, \mathrm{Sm}, \mathrm{Ta}, \mathrm{Nb}, \mathrm{Zr}$, and $\mathrm{Hf}$ are enriched in the samples, indicating derivation from a continental margin source (Figure 19; Pearce, 1983). REE profiles of the Ecca Group indicate that the source rock has undergone intracrustal fractionation, during which LREE were enriched relative to HREE, and Eu was depleted (Figures 24 and 25). This indicates derivation from a continental terrane, such as an old upper continental crust, recycled sedimentary rocks, or differentiated arc terrane (McLennan et al., 1993). The samples are mature rocks that are fine-grained, have a high quartz and $\mathrm{SiO}_{2}$ content, and contain quartz and muscovite silt and sand size grains in thin-sections. This indicates derivation from a mature, highly weathered source or a long residence time in transport. Overall, lithology and composition is indicated to be felsic igneous, metamorphic, or sedimentary from a recycled sedimentary, upper continental crust, or differentiated arc terrane.

\subsubsection{Weathering of the source terranes}

The average shale has a CIA of 70 - 75 (McLennan et al., 1993), so a higher value could indicate a more intensely weathered source that has been exposed for a longer period of time, a humid climate, a long residence time in transport to the basin, or exposure as a soil after deposition. The Karoo Basin was located at $\sim 60^{\circ} \mathrm{S}$ during the Jurassic (Scotese, 2000; de Wit et al., 2002). At that latitude, climate had switched from cold and dry with glaciation during the Carboniferous - early Permian, to warm and dry, especially inland where precipitation was the lowest (Kiddler and Worsley, 2004). In the tropics climate was dry with seasonal monsoons (Parrish, 1993), latitudes $15^{\circ}-40^{\circ}$ or possibly $15^{\circ}-60^{\circ}$ were the desert, and high latitudes were moist enough for forestation (Kiddler and Worsley, 2004). Since the subbasins are geographically close to each other, and paleoflows are relatively similar in the basins, local climate variation between the basins or source areas is not likely. Therefore, CIA will be assumed to be controlled by provenance composition, time in transport, and global climate.

Low to moderate (67 - 71) CIA and moderate to high ICV values in the Ecca and Beaufort groups indicate that a low to moderate degree of weathering altered the sediment during erosion and transport (Figure 15). These values agree with previous studies (Parrish, 1993; Kiddler and Worsley, 2004) that the climate was likely arid, characterized by lower chemical weathering rates. Given constant, arid climate conditions, sediment derived from primary igneous or metamorphic source rocks, including volcanic ash, exposed in tectonically active 
highlands tend to have low CIA values and high ICV values, whereas sediment derived from stable old cratonic rocks and/or recycling of uplifted sedimentary rocks are more likely have moderate CIA and moderate ICV values. The low to moderate CIA and moderate to high ICV values of Ecca and Beaufort Group mudstones are interpreted to represent mixing of sediment from primary igneous source rocks with lesser amounts of sediment from old cratonic rocks or recycled sedimentary rocks.

$\mathrm{Zr}$ is enriched in recycled sedimentary rocks through heavy mineral concentration of zircon. Trace elements $\mathrm{Zr}$ and $\mathrm{Th}$ are only slightly enriched when compared to shales from active margins, possibly indicating a recycled sedimentary source that has undergone heavy mineral enrichment (Figure 22; McLennan et al., 1993). Zircon was not identified in XRD, but that may be because there is such a small amount of zircon $(\mathrm{Zr}=107-218 \mathrm{ppm})$ in the sample. Trace element $\mathrm{U}$ is depleted during weathering by the process of oxidation and subsequent dissolution of $\mathrm{U}$. $\mathrm{U}$ is depleted in many samples above the base of the Laingsburg and Ripon formations, but not in samples below (Figure 21). This indicates the source switched from a less mature source to a more mature source, that climate became more humid, or that sediment spent more time in transport (McLennan et al., 1993).

\subsubsection{Age of the source terranes}

$\mathrm{Sm}-\mathrm{Nd}$ data reveals the whole-rock age of the samples. In the lower and middle Ecca Group of the Laingsburg subbasin, $\mathrm{T}_{\mathrm{CHUR}}$ increases (from $530 \mathrm{Ma}$ to $850 \mathrm{Ma}$ ) and $\varepsilon \mathrm{Nd}$ decreases (from -6.0 to -8.6) upsection from the Prince Albert to the Vischkuil formations, and then

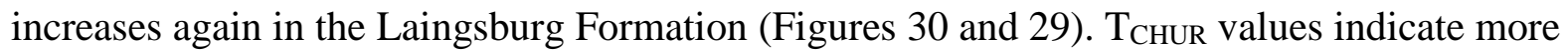
contribution of mud from Precambrian sources upsection, and more from Paleozoic sources downsection.

\subsubsection{Provenance trends}

Provenance is similar in both subbasins, but may not have been constant. Chlorite is present in some formations, CIA values decrease upsection, ICV values increase upsection, $\mathrm{TiO}_{2} / \mathrm{Al}_{2} \mathrm{O}_{3}$ increases upsection, $\mathrm{Th} / \mathrm{U}$ increases upsection, and $\mathrm{T}_{\mathrm{CHUR}}$ increases upsection. These observations indicate provenance changed during deposition of the Ecca Group. Chlorite may indicate contributions from a metamorphic source. The trend in CIA and ICV indicate more contribution from a less weathered source upsection, but increasing $\mathrm{Th} / \mathrm{U}$ indicates more contribution from a more weathered source upsection. A crossplot of CIA versus Th/U indicates that major elements and $U$ do not change at the same rate during weathering, so the contrast in the two weathering indicators could be due to $U$ being depleted faster than major elements during weathering or after deposition. Increasing $\mathrm{TiO}_{2}$ content upsection indicates more contribution from mafic sources upsection. Increasing $\mathrm{T}_{\mathrm{CHUR}}$ indicates more contribution from an older source upsection.

\subsubsection{Provenance terranes}

The most limiting data on provenance is $\mathrm{T}_{\mathrm{CHUR}}$ and $\varepsilon \mathrm{Nd}$, which indicate a source, or mix of sources, Cambrian - Cryogenian (530-850 Ma) in age. Potential sources of this age are granites of the Pan-African Orogenic belts, granites of the North Patagonian and Deseado Massifs, and a fraction of the sediment from the Cape Supergroup of the Cape Fold Belt. Provenance may be one of these terranes, or in the case of the granite, sub-terranes of larger 
terranes. Provenance could also be a mix of these terranes with those younger and older than the model age. If sources mixed, the Gondwanide Magmatic Arc would be the only provider of young, Permian age sediment, and older sediment could have come from the Cape Fold Belt, the Namaqua Natal Metamorphic Province, or the Kalahari Craton. Model ages indicate that a significant fraction of the sediment would have to come from Permian - Cryogenian age sources, because a significant contribution from the Mesoproterozoic-Mesoarchean Namaqua-Natal or Kalahari Craton would increase the model age. Mineralogy indicates a metamorphic or possibly recycled sedimentary source. All of the terranes contain metamorphic rocks, but only the Cape Fold Belt contains sedimentary rocks. Major elements indicate the source switched from a moderately weathered source to a less weathered source upsection. The climate was arid, so weathering indices for most of the sources would be low to moderate. The Gondwanide Magmatic Arc would be expected to contribute less weathered sediment because it is composed mostly of fresh igneous rocks, but the long transport distance to the basin probably weathered sediment before it reached the basin. The Dwyka Group of the Cape Fold Belt, however, is glacial and has low CIA values and could have supplied the Karoo Basin minimally weathered recycled sediment. The Cape Supergroup of the Cape Fold Belt may have contributed moderately weathered sediment as well due to the short transport distance to the basin. Trace elements and REE indicate the source is an old upper continental crust, recycled sedimentary rock, or differentiated arc terrane. All of the potential terranes fall into one of those categories. The Gondwanide Magmatic Arc is a young differentiated arc terrane, and the REE profile of Ecca and Beaufort Group mudrock samples are similar to the profiles of volcanic tuffs from the Ecca and Beaufort groups and the Choiyoi and Puesto Viejo terranes of the Gondwanide Magmatic Arc; however Karoo mudstones do not have as much LREE enrichment on average and have a more significant negative Eu anomaly than the lower Choiyoi Group and Puesto Viejo Group (Figures 24, 25, and 33; McKay et al., 2016). This indicates that sediment of the Ecca and Beaufort groups did not come solely from the Gondwanide Magmatic Arc. In order to constrain provenance, previous studies must be considered. 


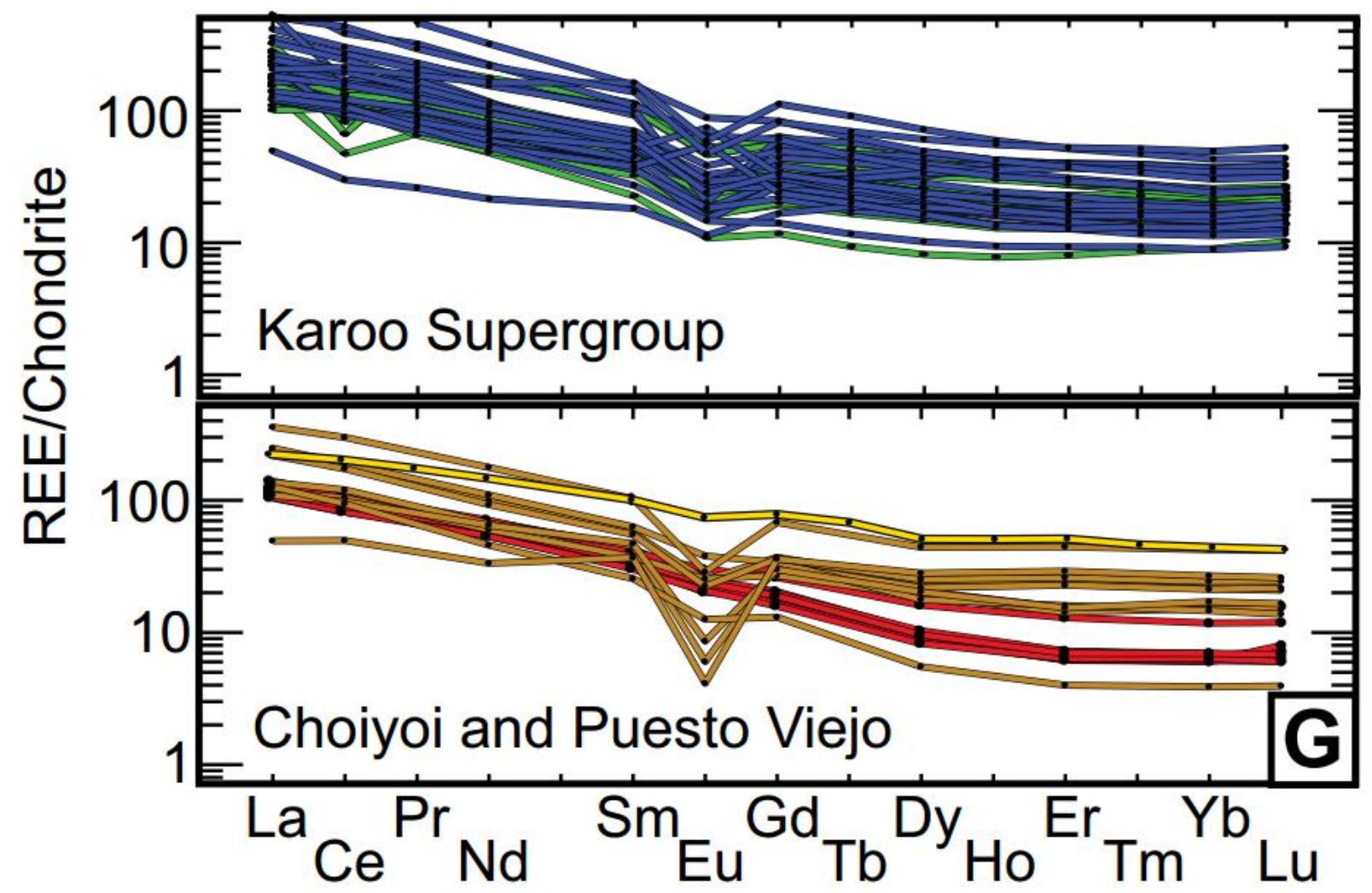

Figure 33: REE profile of volcanic tuffs from the Ecca (blue) and Beaufort (green) groups of the Karoo Basin, and the Choiyoi (upper=gold, lower=red) and Puesto Viejo (yellow) groups of the Gondwanide Magmatic Arc (McKay et al., 2016).

\subsubsection{Integration with previous studies}

Geochemical studies of the Skoorsteensburg Formation (Andersson et al., 2003, 2004, 2006) support the results of this study. Model ages and $\varepsilon N d$ values are similar, as well as CIA values. A Detrital zircon study of the Ecca and Beaufort groups support increasing $\mathrm{T}_{\mathrm{CHUR}}$ and $\varepsilon N d$ values, showing greater amounts of Ordovician, Neoproterozoic, and Mesoproterozoic age zircon upsection and less Permian age zircon upsection (Dean, 2014). Paleoflow direction indicates derivation of the Ecca and Beaufort groups from southern sources (Ryan and Whitfield, 1979; Johnson, 1991; Cole, 1992; Veevers, 1994; Wickens, 1996; Wickens and Bouma, 2000). Sources to the south of the Karoo Basin are the Cape Fold Belt, Saldania Belt of the Pan-African Orogenic belts, North Patagonian and Deseado Massifs, and Gondwanide Magmatic Arc.

Sediment pathways from the Gondwanide Magmatic Arc would cross the other terranes, picking up Cambrian - Ectasian age (500 - $1300 \mathrm{Ma})$ sediment along the transport path to the Karoo Basin (Figure 34). Through time, proportions of sediment from each terrane changed, and composition of the arc may have changed. As the Cape Fold Belt was deformed and the overlying Dwyka Group was exposed to erosion, more sediment was contributed from the Cape Fold Belt. Increased contribution from the Dwyka Group, and decreased contribution from the Gondwanide Magmatic Arc, increased $\mathrm{T}_{\mathrm{CHUR}}$, increased the number of Neo- and Mesoproterozoic detrital zircon (Dean, 2014), decreased CIA, increased ICV, and may have increased Th/U in the Karoo Basin fill. Although the arc may have contributed less sediment 
through time, the sediment may have been more mafic in composition which is why we see more $\mathrm{TiO}_{2}$ upsection.

This study aligns with other studies that have interpreted provenance to have switched between deposition of the Dwyka Group and Ecca Group, and provides evidence for the switch at the base of the Ecca Group. The Cape Supergroup and Dwyka Group underlie the Ecca and Beaufort groups, and are derived from northern continental terranes (Johnson, 1991; Vorster, 2013). The Ecca and Beaufort groups are derived from southern terranes (Johnson, 1991; Vorster, 2013; Dean, 2014). The switch in provenance is due to tectonic activity along the Panthalassan margin of Gondwana, which is discussed in the next section.

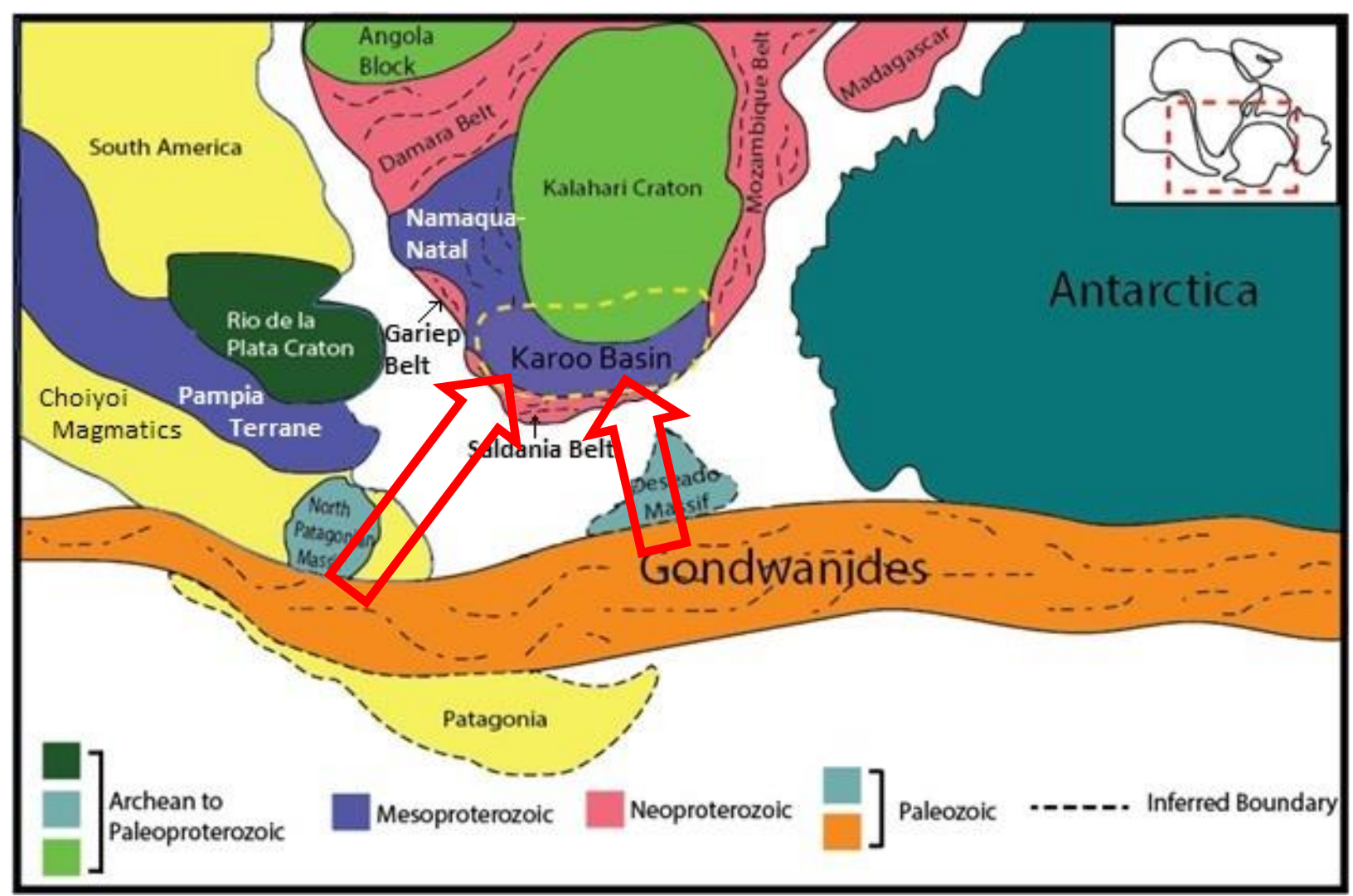

Figure 34: Map of terranes of Permian-Triassic southern Gondwana with provenance arrows interpreted in this study (Modified from Pankhurst et al., 2006; Kleiman and Japas, 2009; Rapela et al., 2011; Uriz et al., 2011; Veevers and Saeed 2013; Vorster 2013, and Dean, 2014).

\subsection{Flexural Basin Models}

\subsubsection{Retroarc Foreland Basin}

The Karoo Basin is generally interpreted as a retroarc foreland basin. In this model, subsidence resulted from flexure driven by crustal loading by the Cape Fold Belt and Gondwanide Magmatic Arc (Figure 1A; Cole, 1992; Catuneanu et al., 1998). This model is supported by: 1) thinning of the lower Ecca Group over the Ceres Syntaxis (Wickens, 1994; Scott et al., 2000) and 2) thinning of Ecca and Beaufort Group formations away from the Cape Fold Belt (Catuneanu et al., 1998). The first indicates syndepositional deformation in the Cape Fold Belt, and syndepositional deformation can be used to infer that crustal loading occurred in 
the Cape Fold Belt coeval with basin subsidence. As for the second, foreland basins strata thin away from the fold/thrust belt (Busby and Ingersol, 1995), just as they do in the Ecca and Beaufort groups.

Provenance interpretations of this study align with this model by providing evidence that provenance of the Ecca Group is, in part, the Cape Fold Belt and Gondwanide Magmatic Arc to the south. The Gondwanide Magmatic Arc was uplifted and contributing sediment to the basin by fluvial transport and airfall ash deposits, indicating subduction was active. The Cape Fold Belt was uplifted and contributing sediment at the time of deposition of the Ecca Group, indicating that crustal loading occurred during early subsidence of the Karoo Basin. Crustal loading on the southern margin of the Karoo Basin was coeval with deposition of the Ecca Group indicating that crustal loading drove subsidence.

\subsubsection{Intracratonic Basin}

The intracratonic basin model proposes that the Karoo Basin was formed by flexural subsidence from mantle convection cell flow (Tankard et al., 2009). In this model, convection cells driven mainly by subduction of the paleo-Pacific plate cause downward deflection of the crust, without additional loading by the Cape Fold Belt (Figure 1B; Tankard et al., 2009). The intimate provenance association of the Karoo Basin fill and the Gondwanide Arc and Cape Fold Belt is inconsistent with sole formation of the Karoo basin as an intracratonic basin (e.g., Tankard, 2009). Mantle flow may have contributed to the forces driving subsidence of the Karoo Basin, but during deposition of the Permian-Triassic Ecca and Beaufort groups, the Cape Fold Belt was uplifted and contributing sediment to the Karoo Basin indicating that crustal loading drove subsidence.

\subsection{Influence of the Gondwanide Magmatic Arc and Cape Fold Belt}

Foreland basin fill is typically derived from the associated fold/thrust belt and magmatic arc (Busby and Ingersol, 1995). High relief in the source areas can lead to a high sedimentation rate in a foreland basin. In contrast, low relief in the source areas for intracratonic basins, such as the Williston, Michigan, and Illinois basins of North America, can lead to low sedimentation rate and deposition of carbonates due to low sediment supply (Busby and Ingersol, 1995). In the Karoo Basin, mudstone is deposited in thick units throughout the basin both proximal and distal to the Cape Fold Belt, but is thickest in the subbasins (Johnson et al, 1996). Sedimentation rates have not been calculated due to controversies over chronostratigraphic control (Mckay et al., 2015; Tohver et al., 2015), but mudstone units are 10's to 100's of meters thick and are interbedded with sandstone turbidite sequences that are typically deposited in relatively quick succession of one another (Wickens and Bouma, 2000).

In order for thick mudstone to be deposited between turbidite deposits, the basin could not be sediment starved, but would need a large supply of mud. Moderate to low CIA values that decrease upsection suggest limited chemical weathering, consistent with either an arid climate or a short residence time in the transport system. Given the mudstone geochemistry, mud could have been transported a long distance in an arid climate (Busby and Ingersol, 1995), or by recycling of another nearby mudstone with low CIA (Busby and Ingersol, 1995; Potter et al., 2005). Climate in the Karoo Basin changed from cold and dry in the Early Permian to warm and dry in the Late Permian and Triassic (Kiddler and Worsley, 2004). The inferred location of the Gondwanide Magmatic Arc is 1000 kilometers from the Karoo Basin. Sediment from the arc could have been transported a long distance, but the climate was arid so the sediment was not 
intensely weathered. The Dwyka Group was deformed in the Cape Fold Belt, and consists of glacial deposits with low CIA values (50-70) (Visser and Young, 1990) that, through time, could have supplied the Karoo Basin with more fine-grained sediment than the arc. This transition from a distant arc source to a close mudstone source would result in the decrease seen in CIA values of this study, as well as the increase seen in detrital zircon ages (Dean, 2014) and Sm-Nd model ages of this study. Without the Cape Fold Belt and Gondwanide Magmatic Arc being uplifted, the source areas for the Ecca Group would have had low relief, and large amounts of mud and sand would not have been transported to the Karoo Basin.

In addition to influencing sedimentation rate, the Gondwanide Magmatic arc and Cape Fold Belt influenced sediment dispersal in the Karoo Basin. The Karoo Basin began as an underfilled basin during deposition of the lowermost formations of the Ecca Group, and transitioned to an overfilled basin by the time the Beaufort Group was deposited (Johnson et al., 1996; Tankard et al., 2009). The formation of the Laingsburg and Ripon depocenters could be a result of deformation and uplift of the Cape Fold Belt funneling sedimentation pathways from the Gondwanide Magmatic Arc into the depocenters. Based on zircon ages (Dean, 2014) and $\mathrm{Sm}-\mathrm{Nd}$ ages increasing upsection in the Ecca Group, CIA decreasing and ICV increasing upsection, and a transition from widespread mudstone deposition to mudstone and sandstone deposition in depocenters in the lower Ecca Group (Johnson et al., 1997), the sedimentation path from the arc may have initiated as a line source, with many low-discharge drainages delivering sediment from the arc and newly emerging fold belt to the Karoo Basin and later switched to point sources (Figure 35; Busby and Ingersol, 1995; Scott et al., 2000). Once the point source(s) were formed, sedimentation was concentrated into the subbasins, less sediment was transported from the arc, and turbidites moved sediment more efficiently outward into the more distal parts of the basin. A large sediment supply and high sedimentation rate near the fold belt would cause total organic carbon (TOC) content to be lower in proximal parts of the basin due to clastic dilution, and higher in distal parts of the basin, away from the source area where sedimentation rate is lower (Li et al., 2015). The Prince Albert, Whitehill, and Collingham formations may have undergone less dilution during deposition before point sources were formed, while the rest of the Ecca Group and Beaufort Group were diluted after point sources were formed proximal to the Cape Fold Belt. 


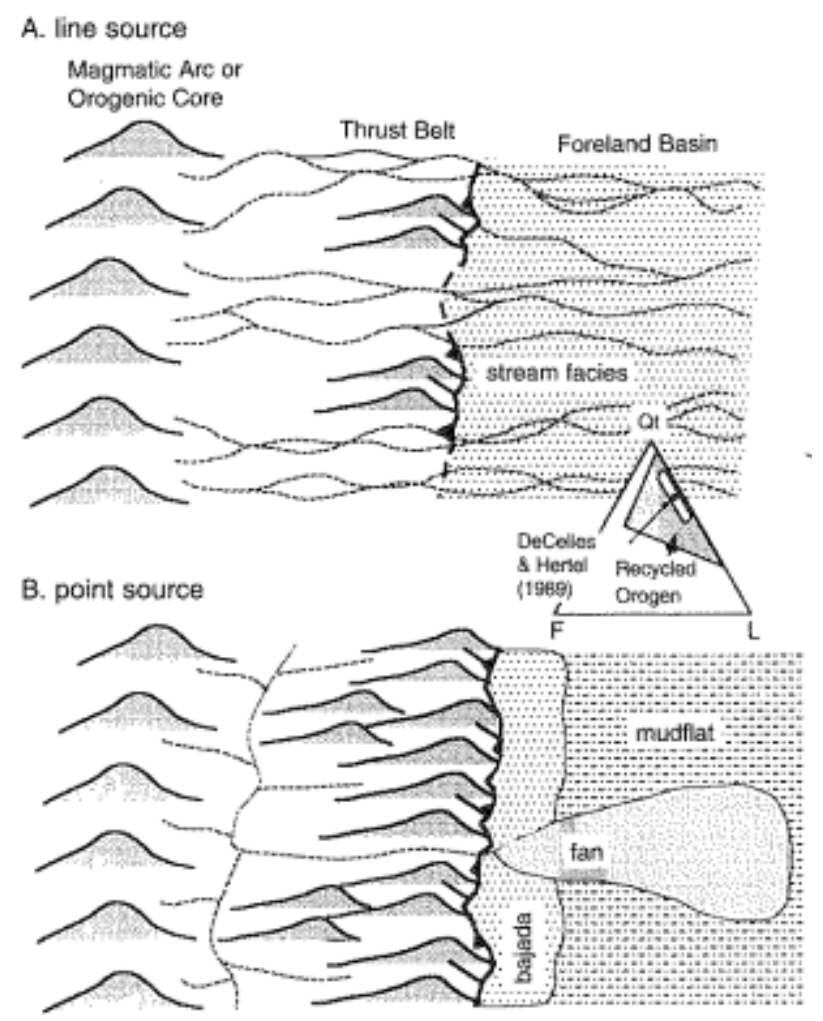

Figure 35: Drainage network types. A) Multiple minor rivers cross the emerging fold belt and empties sediment into the basin as a line source. B) A major river cuts across the uplifted fold belt and empties sediment into the basin as a point source (Taken from Busby and Ingersol, 1995).

\section{Chapter 5: Conclusions}

Texture, mineralogy, major elements, trace elements, rare earth elements, and Samarium and neodymium isotopes were used to interpret the provenance of Ecca and Beaufort Group mudstone. $\mathrm{T}_{\mathrm{CHUR}}$ increases upsection from 530 - $850 \mathrm{Ma}$ and paleocurrents from previous studies (Ryan and Whitfield, 1979; Johnson, 1991; Cole, 1992; Veevers, 1994; Wickens, 1996; Wickens and Bouma, 2000) indicate sediment pathways coming from the southern Permian granite and rhyolite of the Gondwanide Magmatic Arc, Paleozoic-Paleoarchean sedimentary rocks of the Cape Fold Belt, Ordovician-Permian granite of the North Patagonian and Deseado Massifs, and the Paleozoic-Precambrian metamorphic rocks and granite of the Pan-African Orogenic belts. Weathering indices from major elements indicate less weathering upsection. As the Cape Fold Belt deformed, more sediment was eroded from the glaciogenic Dwyka Group and Cape Supergroup and less sediment was transported from the arc. This resulted in less weathered sediment being deposited, sedimentation to be concentrated into the depocenters known as the Tanqua, Laingsburg, and Ripon subbasins, and clastic dilution proximal to the Cape Fold Belt (Scott et al., 2000). The presence of the Cape Fold Belt on the margin of the Karoo Basin coeval with sedimentation in the basin indicates that basin subsidence was driven by crustal loading in the fold belt, and that the Karoo Basin is a retroarc foreland basin. If used as a model for sedimentation in other foreland basins, this would mean 1) early sedimentation would be dominated by fine-grained sediment from the magmatic arc, enter the basin through a line source, and be distributed evenly throughout the basin, 2) deformation in the fold/thrust belt 
would control the switch in source terranes for basin fill, the transition from a line source to a point source, and the distribution of sediment in the basin, and 3) clastic dilution would lower TOC in the depocenters after point sources were formed.

\section{References}

Allen, P. A. (2008). From landscapes into geological history. Nature, 451(7176), 274-276.

Andersson, P. O. D., Johansson, Å., \& Kumpulainen, R. A. (2003). Sm-Nd isotope evidence for the provenance of the Skoorsteensburg Formation, Karoo Supergroup, South Africa. Journal of African Earth Sciences, 36(3), 173-183.

Andersson, P. O. D., Worden, R. H., Hodgson, D. M., \& Flint, S. (2004). Provenance evolution and chemostratigraphy of a Paleozoic submarine fan-complex: Tanqua Karoo Basin, South Africa. Marine and Petroleum Geology, 21(5), 555-577.

Andersson, P. O. D., \& Worden, R. H. (2006). Stratigraphic variations in mudstone mineral assemblages from a submarine fan-complex: Karoo Basin, South Africa. Clay Minerals, 41(4), 839-852.

Atwood, D. A. (Ed.). (2013). The rare earth elements: fundamentals and applications. John Wiley \& Sons.

Bailie, R., Armstrong, R., Reid, D., (2007). Composition and single zircon U-Pb emplacement and metamorphic ages of the Aggeneys Granite Suite, Bushmanland, South Africa. South African Journal of Geology, 110, p. 87-110.

Bhatia, M. R. (1985). Rare earth element geochemistry of Australian Paleozoic graywackes and mudrocks; provenance and tectonic control: Sedimentary Geology, 45(1-2), 97-113.

Bhatia, M. R., \& Crook, K. A. (1986). Trace element characteristics of greywackes and tectonic setting discrimination of sedimentary basins. Contributions to mineralogy and petrology, 92(2), 181193.

Blignault, H. J., \& Theron, J. N. (2012). Modes of Sedimentation and Glaciological Aspects of The Permo-Carboniferous Dwyka Group in the Elandsvlei-Elandsdrif Area, South Africa. South African Journal of Geology,115(2), 211-224.

Booth, P. W. K. (2011). Stratigraphic, structural and tectonic enigmas associated with the Cape Fold Belt: challenges for future research. South African Journal of Geology, 114(3-4), 235-248.

Bouma, A. H. (2000). Coarse-grained and fine-grained turbidite systems as $\varepsilon N d$ member models: applicability and dangers. Marine and Petroleum Geology, 17(2), 137-143.

Bouma, A. H. (2004). Key controls on the characteristics of turbidite systems. Geological Society, London, Special Publications, 222(1), 9-22.

Bouma, A. H. Wickens, (1994). Tanqua Karoo, ancient analog for fine-grained submarine fans. In Submarine fans and turbidite systems: Sequence stratigraphy, reservoir architecture, and production characteristics: Gulf Coast Section SEPM Foundation, 15th Research Conference Proceedings, 23-34. 
Busby, C. J., \& Ingersoll, R. V. (Eds.) (1995). Tectonics of sedimentary basins (Vol. 579). Oxford: Blackwell Science.

Calvert, S. E. (1974). Deposition and diagenesis of silica in marine sediments. International Association of Sedimentologists, Spec. Pub, 1, 273-299.

Catuneanu, O., Hancox, P. J., \& Rubidge, B. S. (1998). Reciprocal flexural behavior and contrasting stratigraphies: a new basin development model for the Karoo retroarc foreland system, South Africa. Basin Research, 10(4), 417-439.

Chemale Jr, F., Scheepers, R., Gresse, P. G., \& Van Schmus, W. R. (2011). Geochronology and sources of late Neoproterozoic to Cambrian granites of the Saldania Belt. International Journal of Earth Sciences, 100(2-3), 431-444.

Cole, D. I. (1992). Evolution and development of the Karoo Basin. Inversion tectonics of the Cape Fold Belt, Karoo and cretaceous basins of Southern Africa, 87-99.

Cornell, D.H., Thomas, R.J., Gibson, R., Moen, H.F.G., Reid, D.L., Moore, J.M. and Gibson, R.L., (2006). The Namaqua-Natal Province. (Eds.) The Geology of South Africa, Geological Society of South Africa. Johannesburg Council for Geoscience, Pretoria, p. 325-379.

Cox, R., Lowe, D. R., \& Cullers, R. L. (1995). The influence of sediment recycling and basement composition on evolution of mudrock chemistry in the southwestern United States. Geochimica et Cosmochimica Acta, 59(14), 2919-2940.

DePaolo, D. J., \& Wasserburg, G. J. (1976a). Nd isotopic variations and petrogenetic models. Geophysical Research Letters, 3(5), 249-252.

DePaolo, D. J., \& Wasserburg, G. J. (1976b). Inferences about magma sources and mantle structure from variations of^ ${ }^{\wedge}(143) \mathrm{Nd} / \wedge(144) \mathrm{Nd}$. Geophysical Research Letters, 3(12), 743-746.

de Wit, M. J., Ghosh, J. G., de Villiers, S., Rakotosolofo, N., Alexander, J., Tripathi, A., \& Looy, C. (2002). Multiple Organic Carbon Isotope Reversals across the Permo-Triassic Boundary of Terrestrial Gondwana Sequences: Clues to Extinction Patterns and Delayed Ecosystem Recovery. The Journal of Geology, 110(2), 227-240.

De Wit, M. J., \& Ransome, I. G. (1992). Regional inversion tectonics along the southern margin of Gondwana. Inversion tectonics of the Cape Fold Belt, Karoo and Cretaceous basins of southern Africa, 15-21.

Dickin, A. P. (2005). Radiogenic isotope geology. Cambridge University Press.

Dickinson, W. R. (1974). Plate tectonics and sedimentation. Society of Economic Paleontologists and Mineralogists Special Publication 22, p. 1-27.

Evensen, N., Hamilton, P. J., \& O'nions, R. K. (1978). Rare-earth abundances in chondritic meteorites. Geochimica et Cosmochimica Acta, 42(8), 1199-1212.

Fedo, C. M., Nesbitt, H. W., \& Young, G. M. (1995). Unraveling the effects of potassium metasomatism in sedimentary rocks and paleosols, with implications for paleoweathering conditions and provenance. Geology, 23(10), 921-924.

Fildani, A., Drinkwater, N.J., Weislogel, A., McHargue, T., Hodgson, D.M., Flint, S. (2007). Age 
controls on the Tanqua and Laingsburg deep-water systems: New insights on the evolution and sedimentary fill of the Karoo Basin, South Africa, Journal of Sedimentary Research, 77, 901908.

Fildani, A., Romans, B.W., Fosdick, J.C., Crane, W.H., and Hubbard, S.M., (2008). Orogenesis of the Patagonian Andes as reflected by basin evolution in southernmost South America, in Spencer, J.E., and Titley, S.R., eds., Ores and orogenesis: Circum-Pacific tectonics, geologic evolution, and ore deposits: Arizona Geological Society Digest 22, p. 259-268.

Fildani, A., Weislogel, A., Drinkwater, N.J., McHargue, T., Tankard, T., Wooden, J., Hodgson, D., Flint, S. (2009). U-Pb zircon ages from the southwestern Karoo Basin, South Africa Implications for the Permian-Triassic boundary, Geology, 37, 719-722.

Flint, S. A., Hodgson, D. M., Sprague, A. R., Brunt, R. L., Van der Merwe, W. C., Figueiredo, J., Prelat, A., Box, D., Di Celma, C., \& Kavanagh, J. P. (2011). Depositional architecture and sequence stratigraphy of the Karoo basin floor to shelf edge succession, Laingsburg depocentre, South Africa. Marine and Petroleum Geology, 28(3), 658-674.

Geel, C., Schulz, H. M., Booth, P., \& Horsfield, B. (2013). Shale gas characteristics of Permian black shales in South Africa: results from recent drilling in the Ecca Group (Eastern Cape). Energy Procedia, 40, 256-265.

Gresse, P.G., Theron, J.N., Fitch, F.J., Miller, J.A. (1992). Tectonic inversion and radiometric resetting of the basement in the Cape Fold Belt. In de Wit, M.J. and Ransome, I.G.D. (Eds.) Inversion Tectonics of the Cape Fold Belt, Karoo, and Cretaceous Basins of Southern Africa, A.A. Balkema: Rotterdam.

Gresse, P. G., \& Scheepers, R. (1993). Neoproterozoic to Cambrian (Namibian) rocks of South Africa: a geochronological and geotectonic review. Journal of African Earth Sciences (and the Middle East), 16(4), 375-393.

Gresse, P.G., Von Veh, M.W., Frimmel, H.E., (2006). Namibian (Neoproterozoic) to early Cambrian Successions. In: Johnson, M.R., Anhaeusser, C.R. and Thomas, R.J. (Eds.), The Geology of South Africa, Geological Society of South Africa, Johannesburg/Council for Geoscience, Pretoria, p. 395-420.

Gromet, L. P., Haskin, L. A., Korotev, R. L., \& Dymek, R. F. (1984). The "North American shale composite": its compilation, major and trace element characteristics. Geochimica et Cosmochimica Acta, 48(12), 2469-2482.

Gu, X. X. (1994). Geochemical characteristics of the Triassic Tethys-turbidites in northwestern Sichuan, China: implications for provenance and interpretation of the tectonic setting. Geochimica et Cosmochimica Acta, 58(21), 4615-4631.

Halbich, I.W., Fitch, F.J., Miller, J.A. (1983). Dating the Cape Orogeny. Spec. Publ. geol. Soc., S. Afr., 12, p. $149-164$.

Hay, R. L. (1986). Geologic occurrence of zeolites and some associated minerals. Pure and Applied Chemistry, 58(10), 1339-1342. 
Hesse, R. (1989). Silica diagenesis: origin of inorganic and replacement cherts. Earth-Science Reviews, v. 26, p. 253-284.

Hosterman, J. W., \& Whitlow, S. T. (1981). Clay mineralogy of Devonian shales in the Appalachian Basin. Geol. Surv. Open-File Rep.(US);(United States), 81.

Ingersoll, R. V. (1988). Tectonics of sedimentary basins. Geological Society of America Bulletin, 100(11), 1704-1719.

Johnson, M.R. (1991). Sandstone petrography, provenance and tectonic setting in Gondwana context of the southeastern Cape-Karoo Basin. South African Journal of Geology, v. 94, pp., 137-154.

Johnson, M. R., Van Vuuren, C. J., Hegenberger, W. F., Key, R., \& Show, U. (1996). Stratigraphy of the Karoo Supergroup in southern Africa: an overview.Journal of African Earth Sciences, 23(1), 315.

Johnson, M. R., Van Vuuren, C. J., Visser, J. N. J., Cole, D. I., Wickens, H. D. V., Christie, A. D. M., and Brandl, G. (2006). Sedimentary rocks of the Karoo Supergroup. The geology of South Africa, 461-499.

Johnsson, M. J., \& Basu, A. (Eds.). (1993). Processes controlling the composition of clastic sediments (Vol. 284). Geological Society of America.

Kleiman, L. E., \& Japas, M. S. (2009). The Choiyoi volcanic province at 34 S-36 S (San Rafael, Mendoza, Argentina): Implications for the Late Palaeozoic evolution of the southwestern margin of Gondwana.Tectonophysics, 473(3), 283-299.

LaMaskin, T. A., Dorsey, R. J., \& Vervoort, J. D. (2008). Tectonic Controls on Mudrock Geochemisry, Mesozoic Rocks of Eastern Oregon and Western Idaho, USA: Implications for Cordilleran Tectonics. Journal of Sedimentary Research, 78(12), 765-783.

Li, Y., Fan, T., Zhang, J., Wei, X., \& Zhang, J. (2015). Impact of paleoenvironment, organic paleoproductivity, and clastic dilution on the formation of organic-rich shales: a case study about the Ordovician-Silurian black shales, southeastern Chongqing, South China. Arabian Journal of Geosciences, 1-15.

Lopez-Gamundí, O. (2006), Permian plate margin volcanism and tuffs in adjacent basins of west Gondwana: Age constraints and common characteristics, Journal of South American Earth Sciences, 22, 227-238.

Mackenzie, F. T. (Ed.). (2005). Sediments, diagenesis, and sedimentary rocks: treatise on geochemistry (Vol. 7). Elsevier.

McKay, M. (2015). Integrated geochronology and petrogenesis of volcanic suites for tectonic sedimentary studies: Karoo Basin, South Africa. PhD Dissertation, West Virginia University.

McKay, M.P., Weislogel, A.L., Fildani, A., Brunt, R.L., Hodgson, D.M., and Flint, S.S. (2015). U-Pb zircon tuff geochronology from the Karoo Basin, South Africa: Implications of zircon recycling on stratigraphic age controls 1008592 . International Geology Review, v. 57, p. 393-410, doi: $10.1080 / 00206814.2015$. 
McKay, M.P., Coble, M.A., Hessler, A.M., Weislogel, A.L., and Fildani, A., (2016). Petrogenesis and provenance of distal volcanic tuffs from the Permian-Triassic Karoo Basin, South Africa: A window into a dissected magmatic province: Geosphere, v. 12, no. 1, p. 1-14, doi:10.1130/GES01215.1.

McLennan, S. M., Taylor, S. R., McCulloch, M. T., \& Maynard, J. B. (1990). Geochemical and Nd $\square$ Sr isotopic composition of deep-sea turbidites: crustal evolution and plate tectonic associations. Geochimica et Cosmochimica Acta, 54(7), 2015-2050.

McLennan, S. M., Taylor, S. R., McCulloch, M. T., \& Maynard, J. B. (1990). Geochemical and Nd $\square$ Sr isotopic composition of deep-sea turbidites: crustal evolution and plate tectonic associations. Geochimica et Cosmochimica Acta, 54(7), 2015-2050.

McLennan, S. M., Hemming, S., McDaniel, D. K., \& Hanson, G. N. (1993). Geochemical approaches to sedimentation, provenance, and tectonics.Geological Society of America Special Papers, 284, 21-40.

Merriman, R. J., \& Kemp, S. J. (1996). Clay minerals and sedimentary basin maturity. Mineralogical Society Bulletin, 111, 7-8.

Milliken, K. L. (1988). Loss of provenance information through subsurface diagenesis in PlioPleistocene sandstones, northern Gulf of Mexico. Journal of Sedimentary Research, 58(6).

Milliken, K. L. (1989). Petrography and composition of authigenic feldspars, Oligocene Frio Formation, south Texas. Journal of Sedimentary Research,59(3).

Milliken, K. L. (2003). Late diagenesis and mass transfer in sandstone shale sequences. Treatise on geochemistry, 7, 159-190.

Nesbitt, H.W., (2003). Petrogenesis of siliciclastic sediments and sedimentary rocks, in Lentz, D.R., ed., Geochemistry of Sediments and Sediemntary Rocks: Evolutionary Considerations to Mineral Deposit-Forming Environments. Geological Association of Canada, GeoText 4, p. 39-51.

Nesbitt, H. W., \& Young, G. M. (1984). Prediction of some weathering trends of plutonic and volcanic rocks based on thermodynamic and kinetic considerations. Geochimica et Cosmochimica Acta, 48(7), 1523-1534.

Nesbitt, H. W., \& Young, G. M. (1989). Formation and diagenesis of weathering profiles. The Journal of Geology, 129-147.

Parrish, J. T. (1993). Climate of the supercontinent Pangea. The Journal of Geology, 215-233.

Peltonen, C., Marcussen, Ø., Bjørlykke, K., \& Jahren, J. (2009). Clay mineral diagenesis and quartz cementation in mudstones: The effects of smectite to illite reaction on rock properties. Marine and Petroleum Geology, 26(6), 887-898.

Potter, P. E., Maynard, J. B., \& Depetris, P. J. (2005). Provenance of Mudstone. Mud and Mudstone: Introduction and Overview, 157-174.

Priestley, K., McKenzie, D., \& Debayle, E. (2006). The state of the upper mantle beneath southern Africa. Tectonophysics, 416(1), 101-112. 
Roser, B. P., \& Korsch, R. J. (1988). Provenance signatures of sandstone-mudstone suites determined using discriminant function analysis of major-element data. Chemical geology, 67(1), 119-139.

Ryan, P. J., \& Whitfield, G. G. (1979). Basinal analysis of the Ecca and lowermost Beaufort beds and associated coal, uranium and heavy mineral beach sand occurrences. Some sedimentary basins and associated ore deposits of South Africa.

Schieber, J., Krinsley, D., \& Riciputi, L. (2000). Diagenetic origin of quartz silt in mudstones and implications for silica cycling. Nature, 406(6799), 981-985.

Scotese, C. R. (2004). A continental drift flipbook. The Journal of Geology,112(6), 729-741.

Scott, E. D., Bouma, A. H., \& Wickens, H. (2000). Influence of tectonics on submarine fan deposition, Tanqua and Laingsburg subbasins, South Africa. Special Publication-SEPM, 68, 47-56.

Shone, R. W., \& Booth, P. W. K. (2005). The Cape Basin, South Africa: A review. Journal of African Earth Sciences, 43(1), 196-210.

Stow, D. A., Howell, D. G., \& Nelson, C. H. (1985). Sedimentary, tectonic, and sea-level controls. In Submarine fans and related turbidite systems (pp., 15-22). Springer New York.

Środoń, J., Drits, V. A., McCarty, D. K., Hsieh, J. C., \& Eberl, D. D. (2001). Quantitative X-ray diffraction analysis of clay-bearing rocks from random preparations. Clays and Clay Minerals, 49(6), 514-528.

Tankard, A., .Welsink, H., Aukes, P., Newton, R., and Stettler, S. (2009). Tectonic Evolution of the Cape and Karoo Basins of South Africa. Marine and Petroleum Geology 26.8, 1379-412.

Taylor, S. R., \& McLennan, S. M. (1995). The geochemical evolution of the continental crust. Reviews of Geophysics, 33(2), 241-265.

Thamm, A. G., \& Johnson, M. R. (2006). The Cape Supergroup. The geology of South Africa, 443-459.

Tohver, E., Lanci, L., Wilson, A., Hansma, J., \& Flint, S. (2015). Magnetostratigraphic constraints on the age of the lower Beaufort Group, western Karoo basin, South Africa, and a critical analysis of existing U-Pb geochronological data. Geochemistry, Geophysics, Geosystems, 16(10), 36493665 .

Van Lente, B., (2004). Chemostratigraphic trends and provenance of the Permian Tanqua and Laingsburg depocentres, South Western Karoo Basin, South Africa [unpublished Ph.D. thesis]: University of Stellenbosch, 339 p.

Veevers, J. J., Cole, D. I., \& Cowan, E. J. (1994). Southern Africa: Karoo basin and Cape fold belt. Geological Society of America Memoirs, 184, 223-280.

Velde, B. (1985). Possible chemical controls of illite/smectite composition during diagenesis. Mineralogical Magazine, 49(3), 387-391.

Visser, J. N., \& Young, G. M. (1990). Major element geochemistry and paleoclimatology of the PermoCarboniferous glacigene Dwyka Formation and postglacial mudrocks in southern Africa. Palaeogeography, Palaeoclimatology, Palaeoecology, 81(1), 49-57. 
Vorster, C. (2013). Laser ablation ICP-MS age determination of detrital zircon populations in the Phanerozoic Cape and Lower Karoo Supergroups (South Africa) and correlatives in Argentina. $\mathrm{PhD}$ Dissertation.

Weislogel, A.L., McKay, M.P., Dean, J., Fildani A. (2013). Perspectives and perils of using U-Pb zircon geochronology to constrain stratigraphic age: lessons from the Permian-Triassic Karoo basin, South Africa. AGU Fall Meeting Abstracts.

Wickens, H. DeV., (1994). Basin floor building turbidites of the southwestern Karoo Basin, Permian Ecca Group, South Africa: Unpublished Ph.D. disseretation, University of Port Elisabeth, South Africa, 233p.

Wickens, H., \& Bouma, A. H. (2000). The Tanqua fan complex, Karoo Basin, South Africa-Outcrop analog for fine-grained, deepwater deposits. SPECIAL PUBLICATION-SEPM, 68, 153-164.

Wilson, A., Flint, S., Payenberg, T., Tohver, E., Lanci, L. (2014). Architectural styles and sedimentology of the fluvial Lower Beaufort Group, Karoo Basin, South Africa. Journal of Sedimentary Research, v. 84, p. 326-348.

Winter, J. D. (2010). Principles of igneous and metamorphic petrology. Pearson.

Yaalon, D.H. (1961). Mineral Composition of the Average Shale. The Hebrew University, Jerusalem.

\section{Appendix I}

Mineralogy

Ripon Subbasin

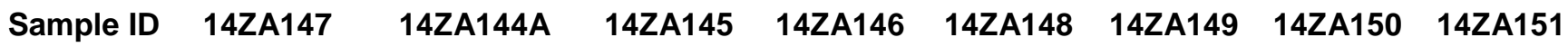

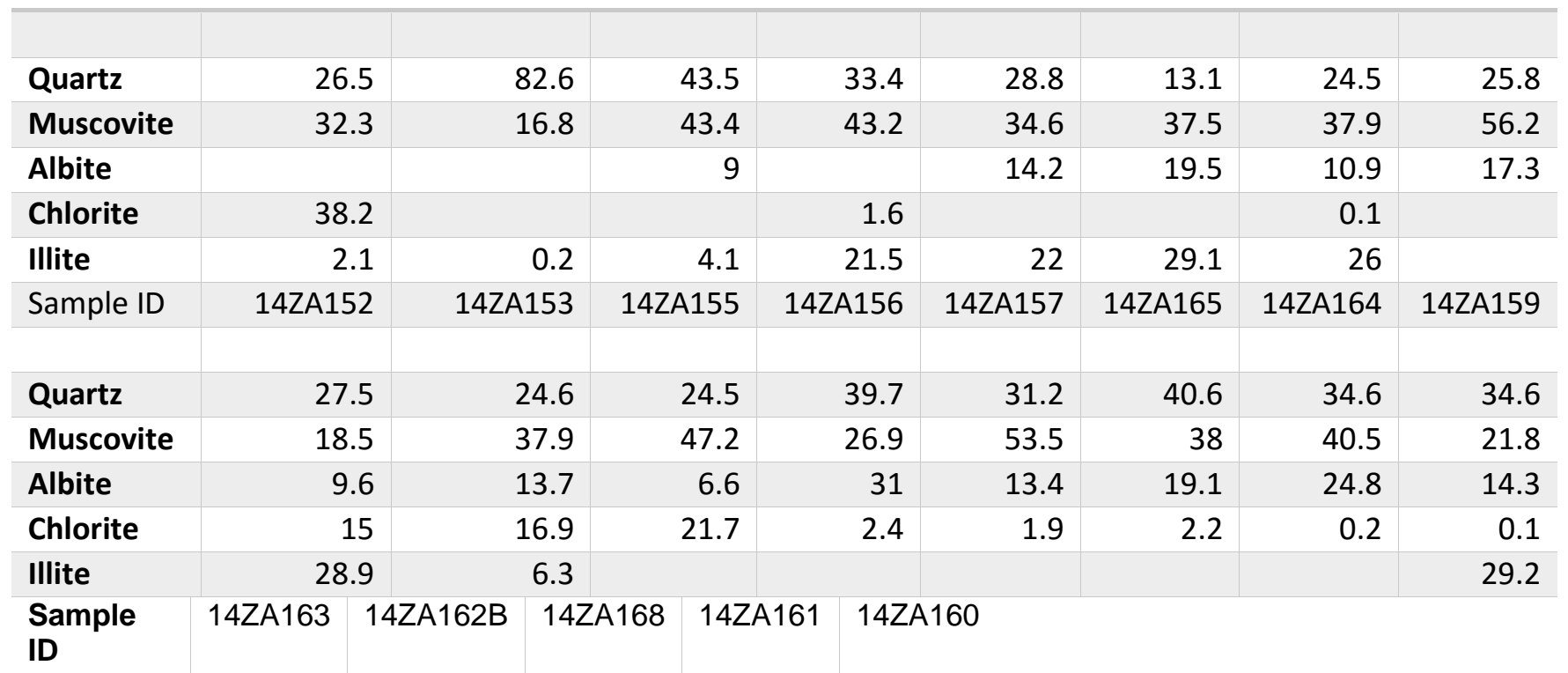




\begin{tabular}{|l|l|l|l|l|l|}
\hline Quartz & 31.7 & 38.4 & 33.5 & 32.5 & 20.1 \\
\hline Muscovite & 40.7 & 46.3 & 29.4 & 51.9 & 29.1 \\
\hline Albite & 11.1 & & 22.1 & 14.1 & \\
\hline Chlorite & & & 15.1 & & \\
\hline Illite & 16.5 & & & & 45.7 \\
\hline
\end{tabular}

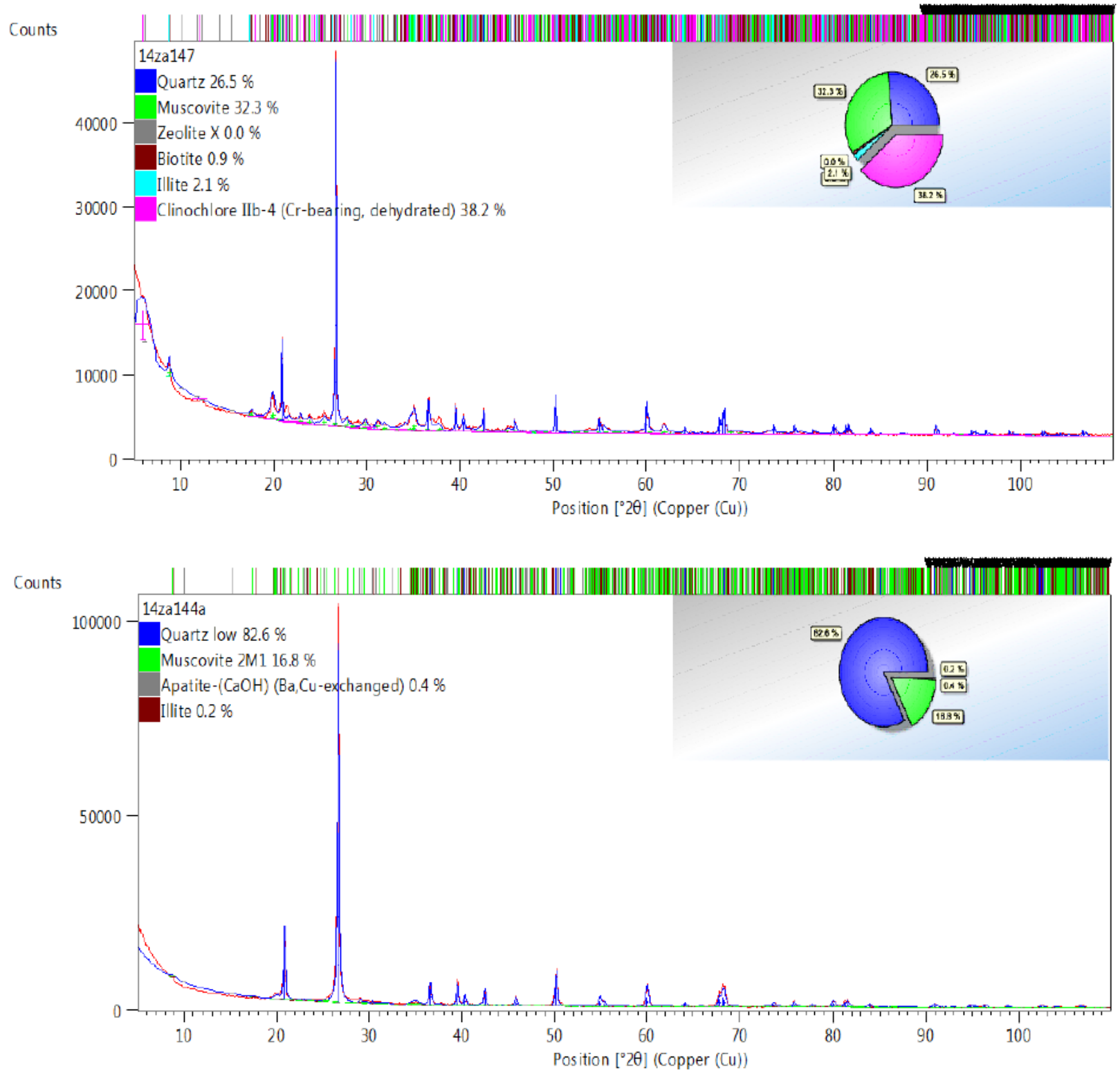



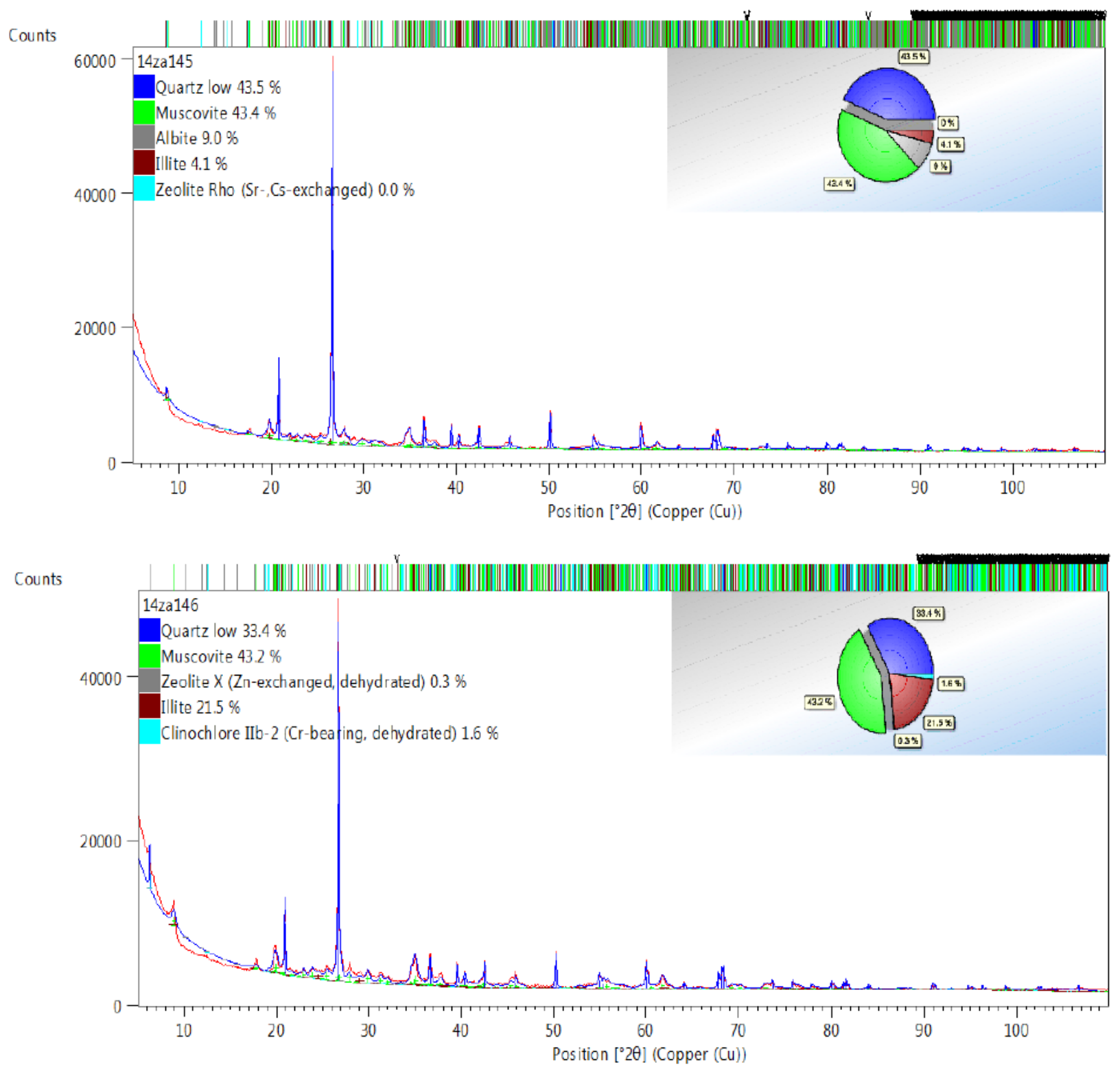


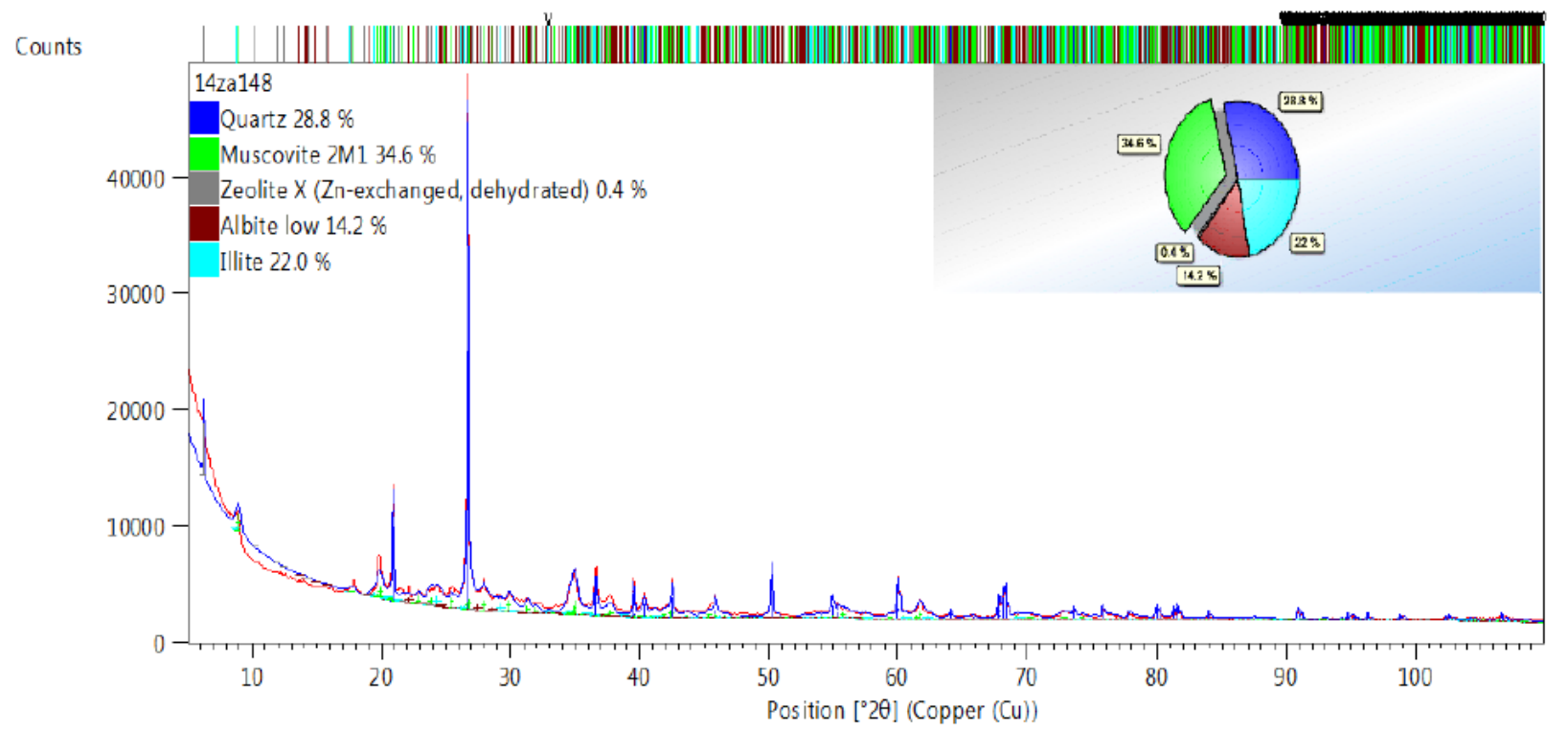

Counts

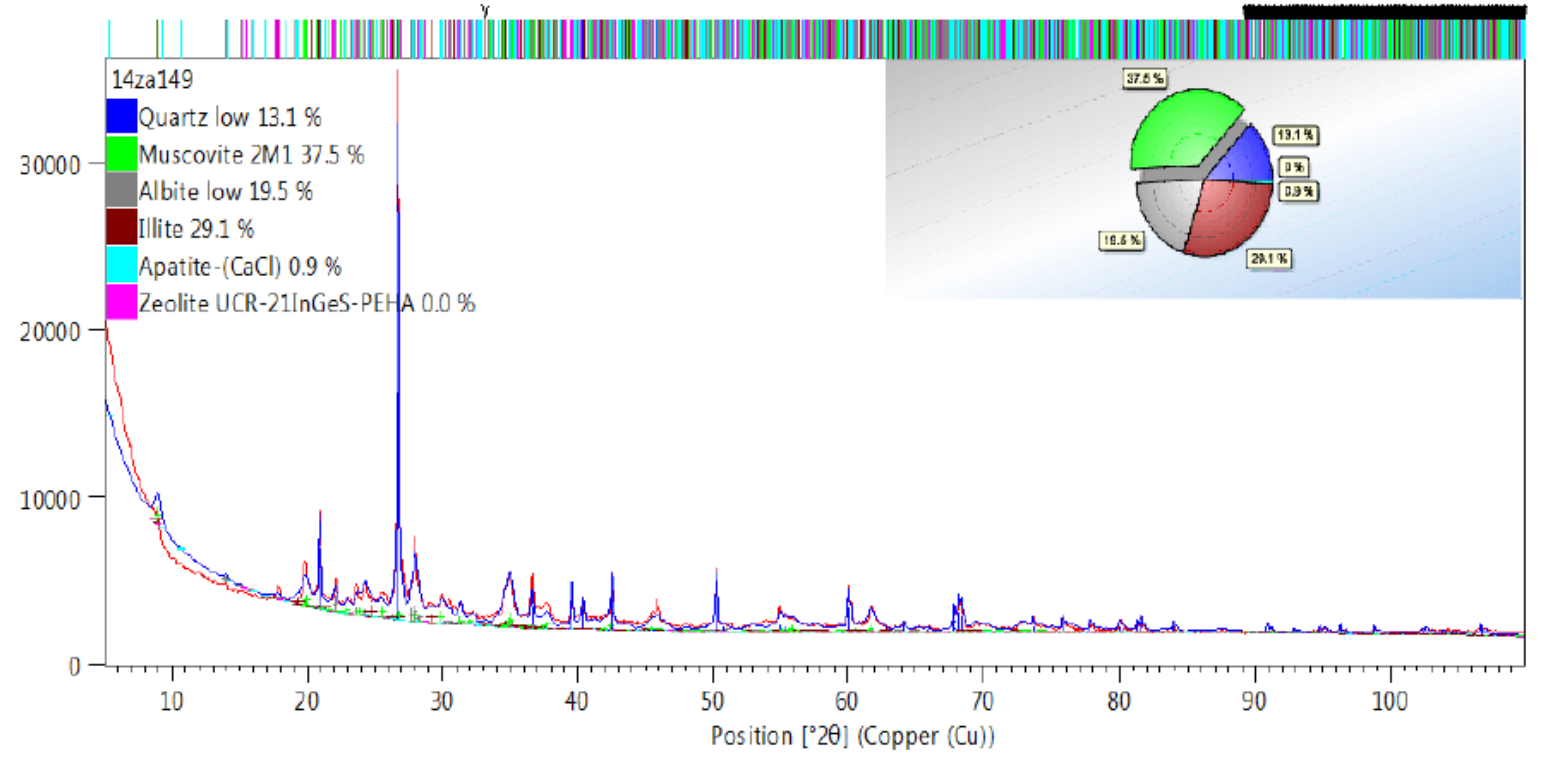



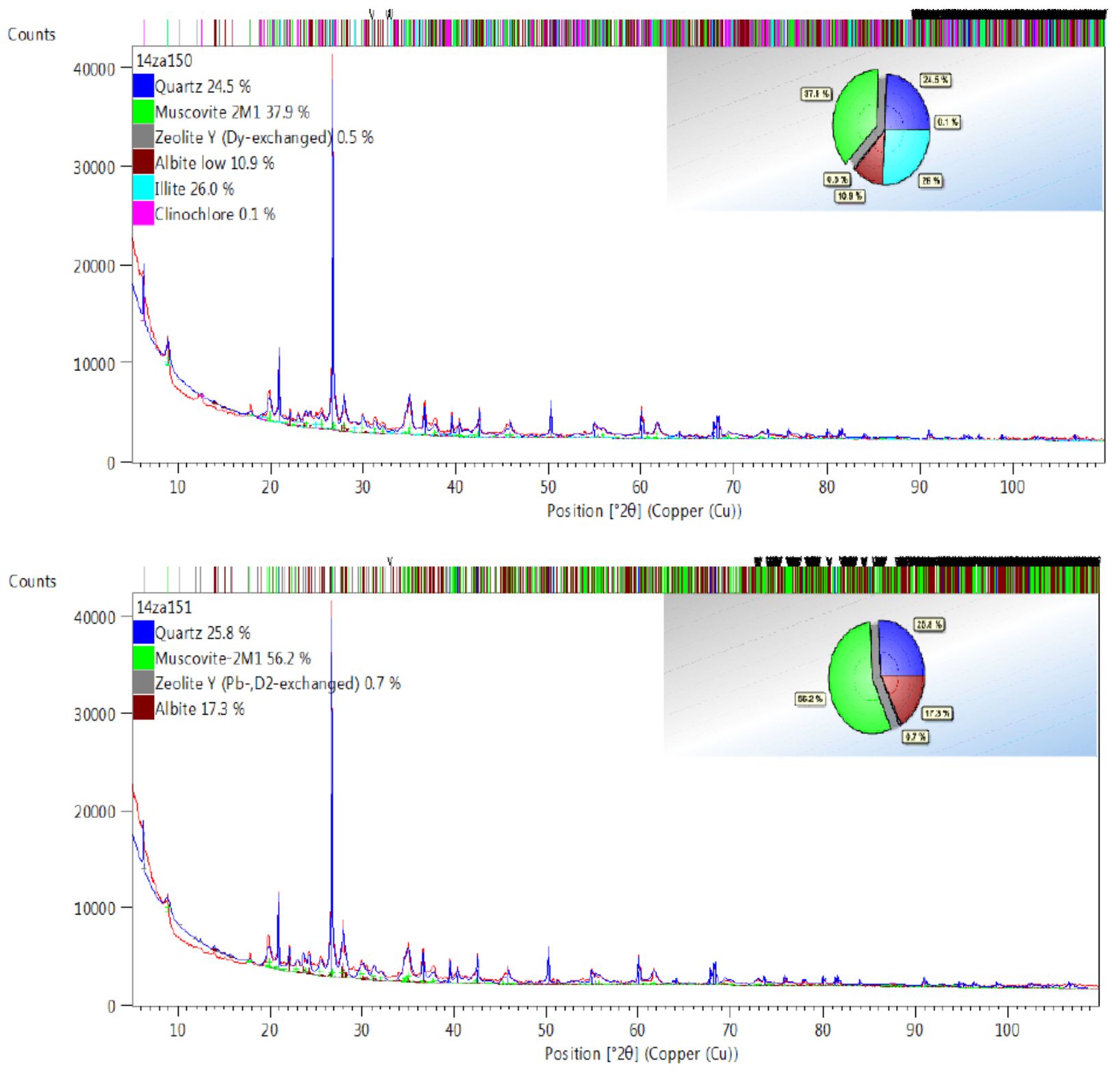


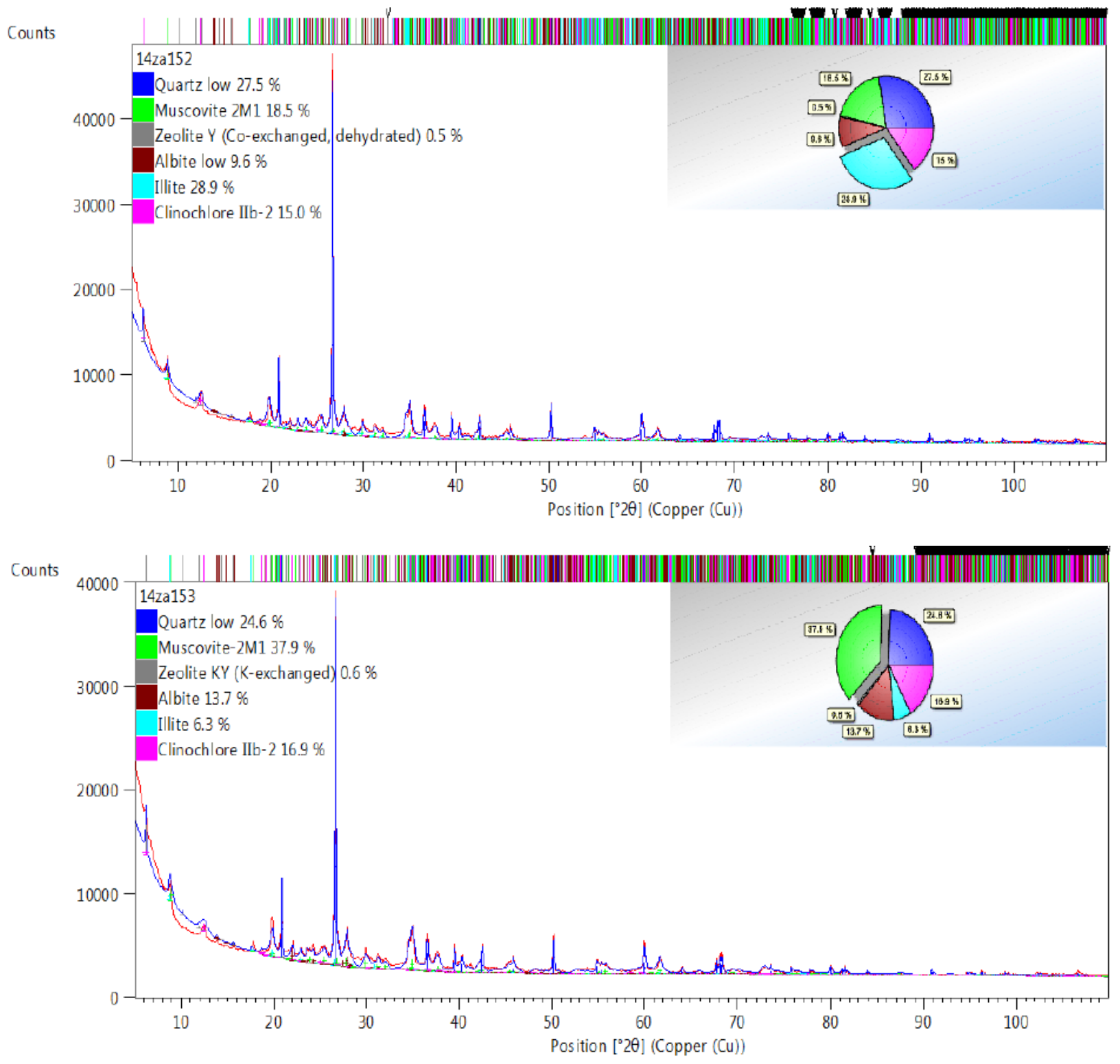


Counts
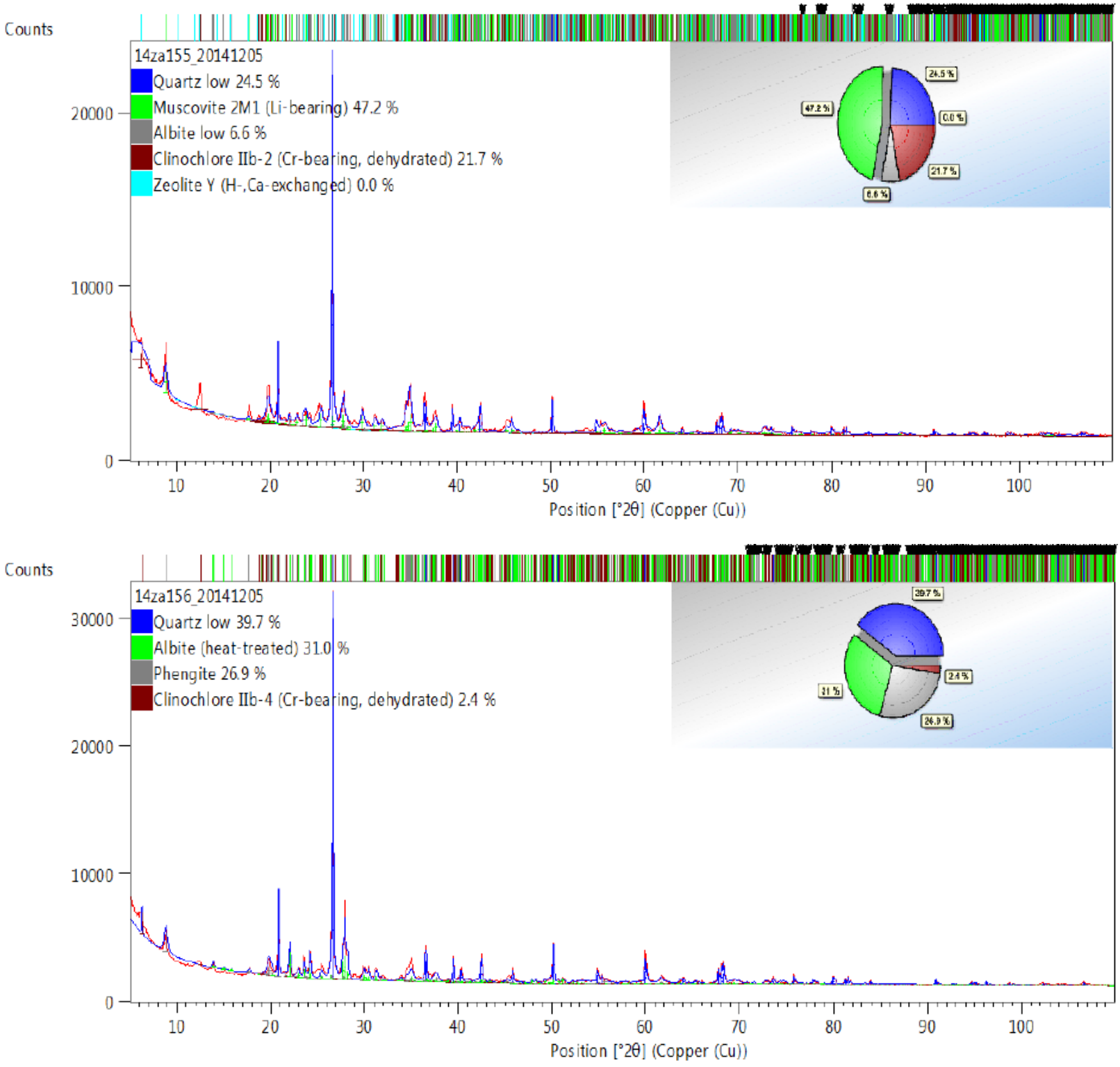

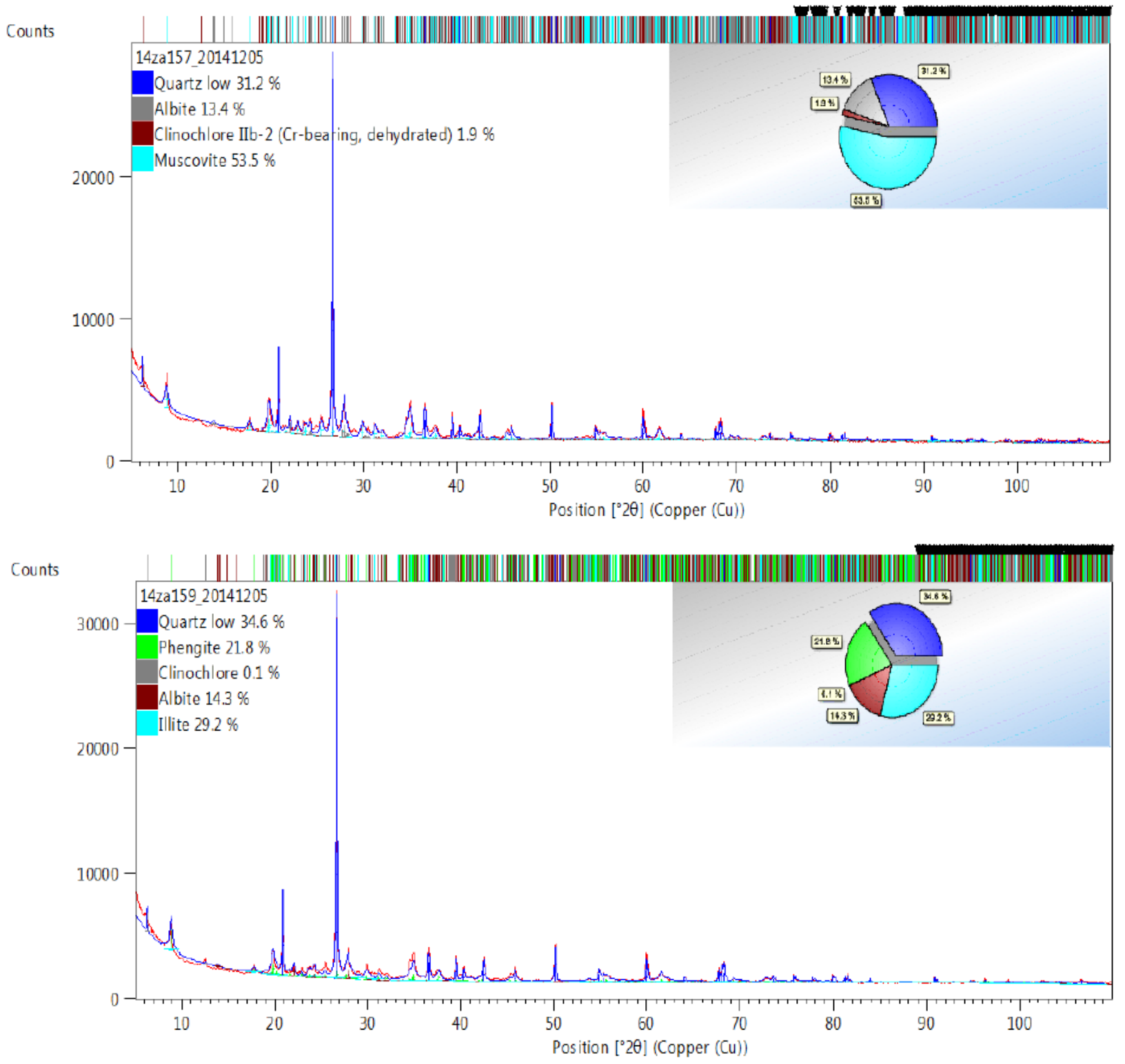

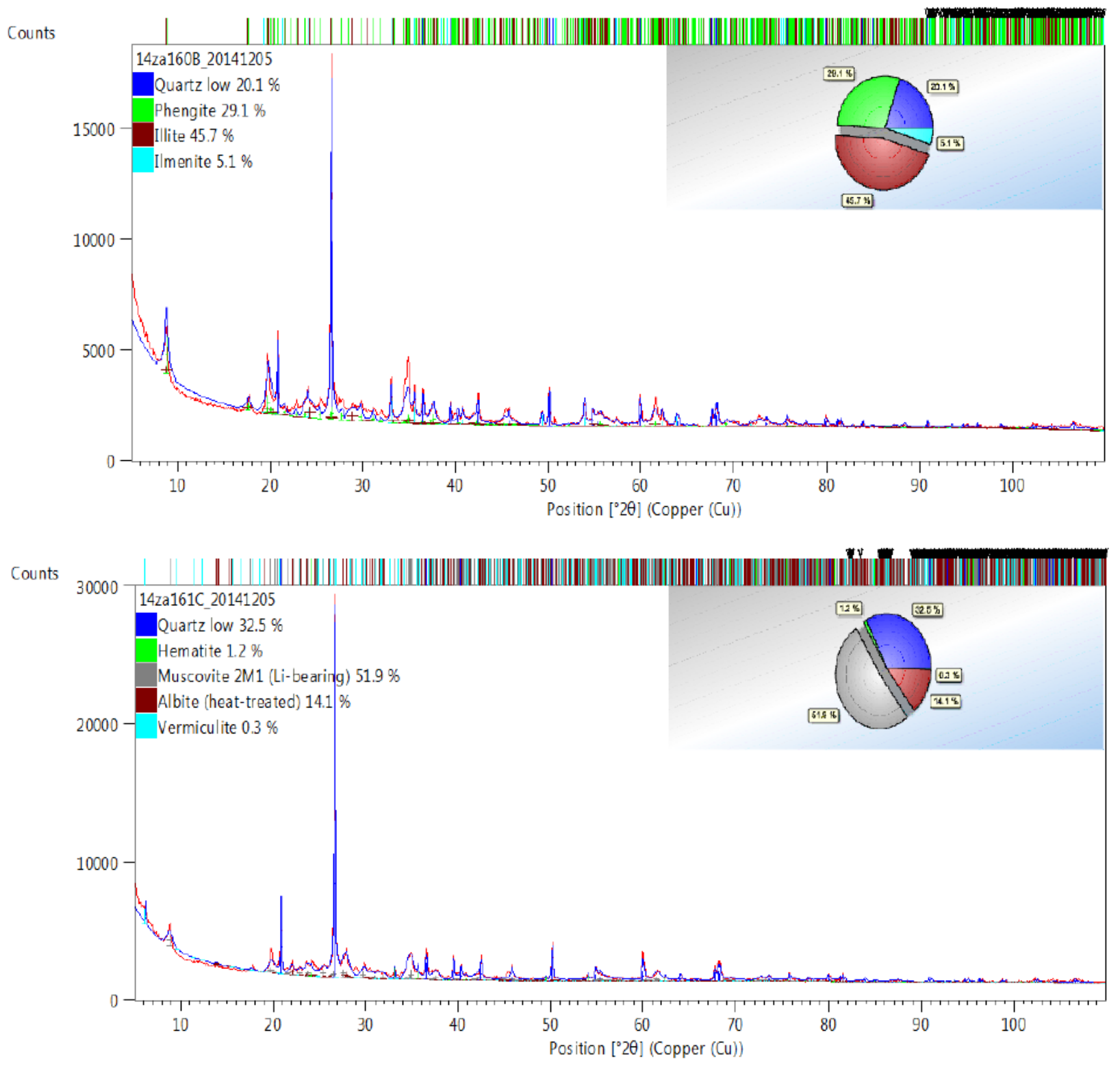


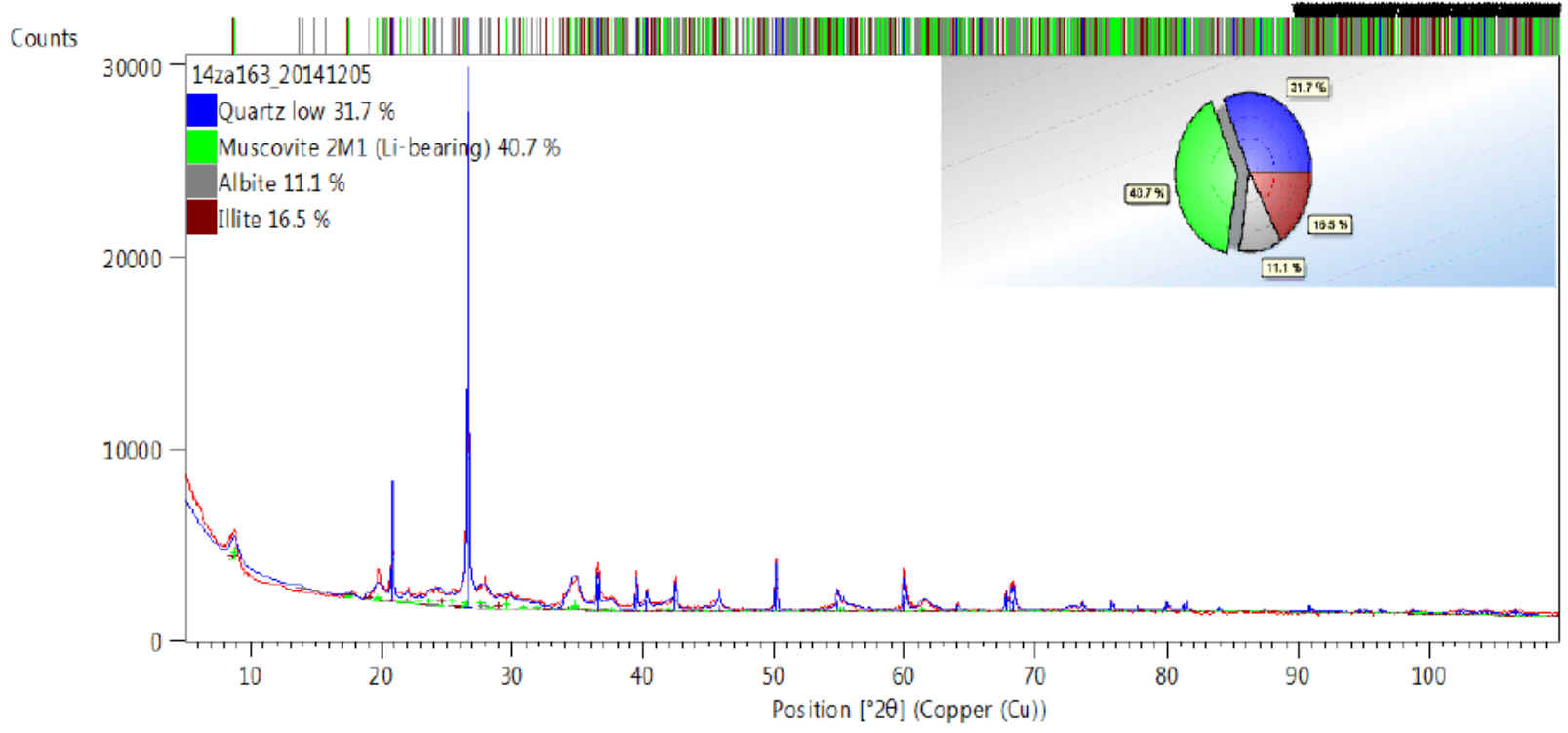

Laingsburg Subbasin

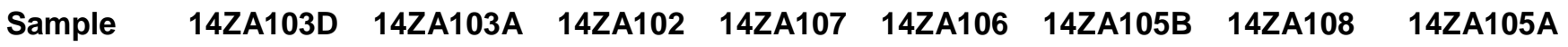
ID

\begin{tabular}{|c|c|c|c|c|c|c|c|c|}
\hline Quartz & 53.7 & 30.4 & 32.7 & 37.4 & 41.8 & 26 & 41.3 & 34.5 \\
\hline Muscovite & 34.7 & 29.4 & 24.9 & 29.7 & 8.1 & 28.1 & 20.7 & 22.9 \\
\hline Albite & 7.8 & 19.8 & 18.5 & 18.1 & 24.4 & 15.3 & 18.5 & 25.9 \\
\hline Chlorite & 1.6 & & & & & 1.7 & 17.4 & 14.6 \\
\hline Illite & 1.8 & 20.4 & 23.9 & 14.8 & 25.8 & 28.9 & 2.1 & 2.2 \\
\hline $\begin{array}{l}\text { Sample } \\
\text { ID }\end{array}$ & 14ZA98A & 14ZA116B & $14 Z A 119$ & 14ZA122 & 14ZA124 & 14ZA130B & 14ZA129B & 14ZA130C \\
\hline Quartz & 24.8 & 27.9 & 30.3 & 23.5 & 33.7 & 32.9 & 29.1 & 24.7 \\
\hline Muscovite & 46.4 & 32.8 & 20.6 & 41.6 & 22.2 & 22.2 & 45 & 37.8 \\
\hline Albite & 14.2 & 11.9 & 14.5 & 16.6 & 11.7 & 13.5 & 13.4 & 20.9 \\
\hline Chlorite & 13.8 & 13.8 & 13.1 & & 2.1 & & 10.8 & \\
\hline Illite & & 13.1 & 21.3 & 18.3 & 29.8 & 31.3 & & 16.6 \\
\hline
\end{tabular}



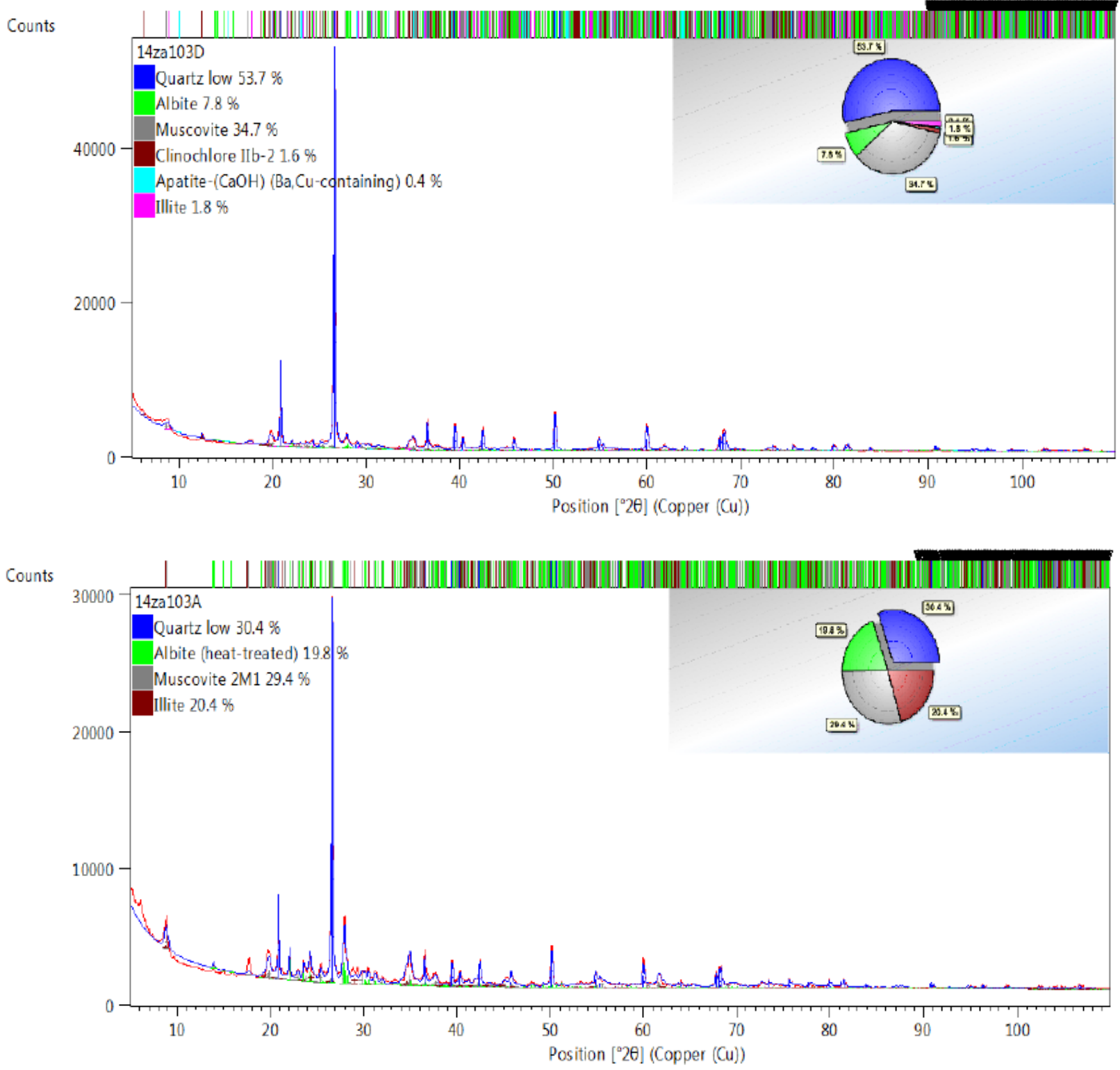


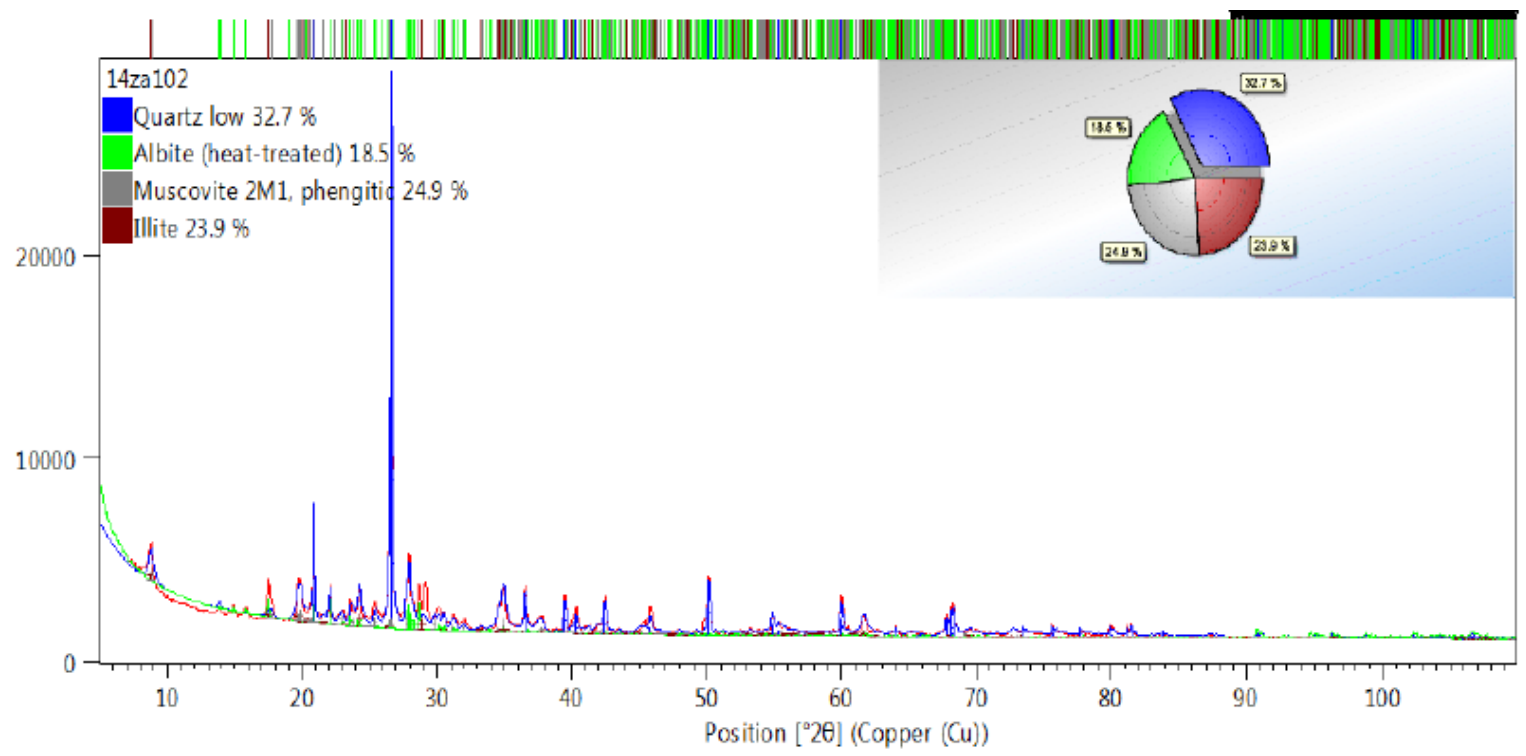

Counts

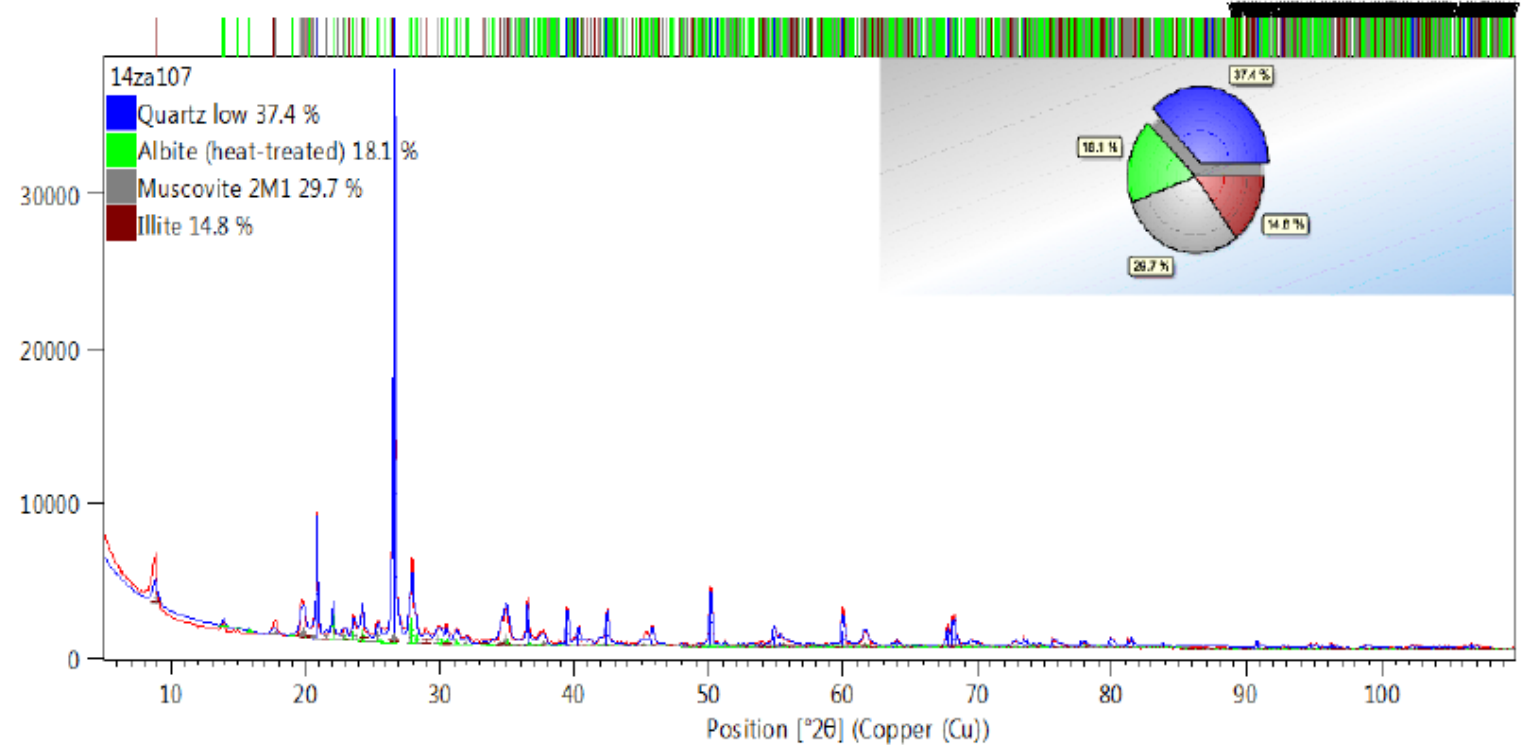



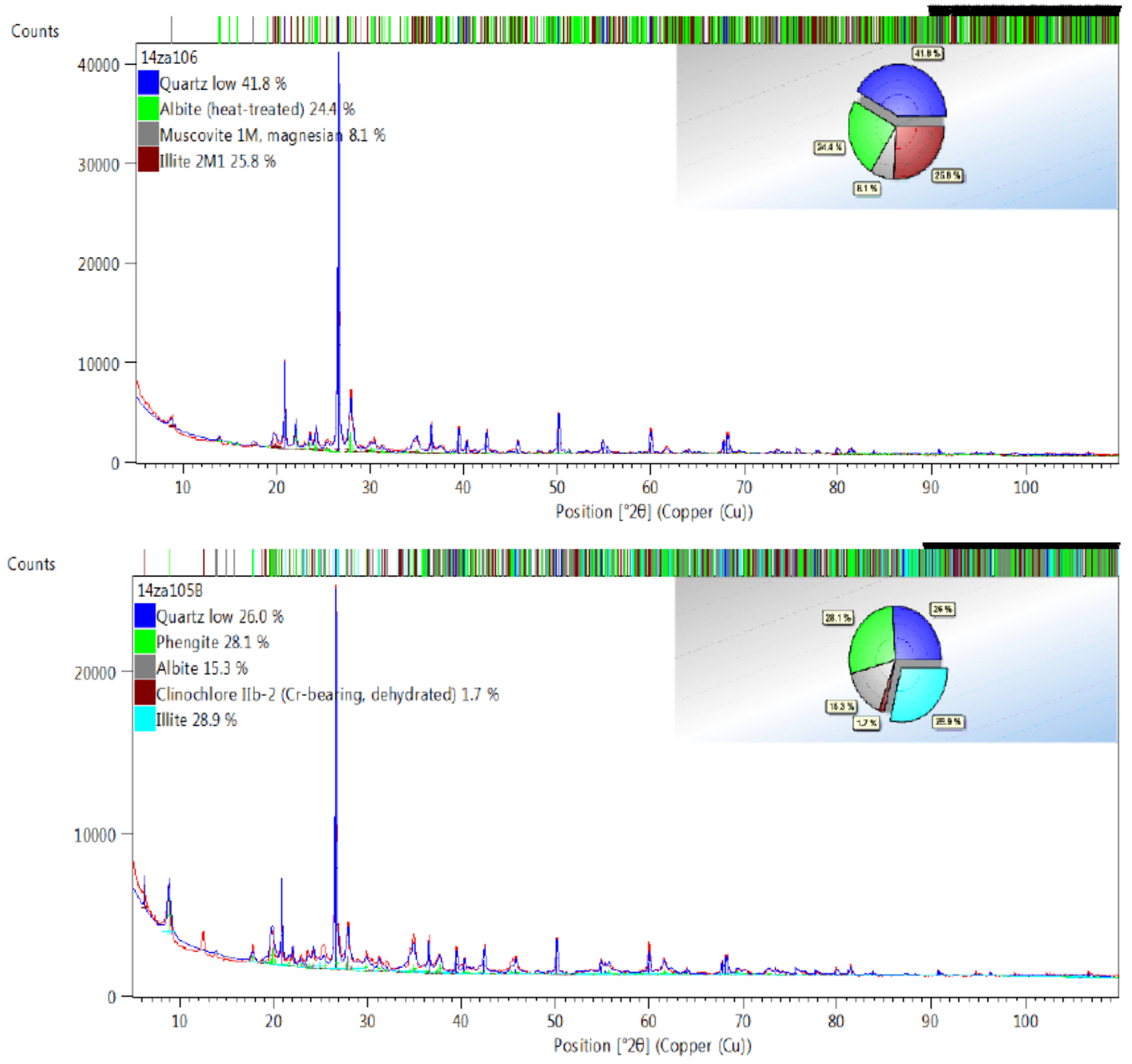

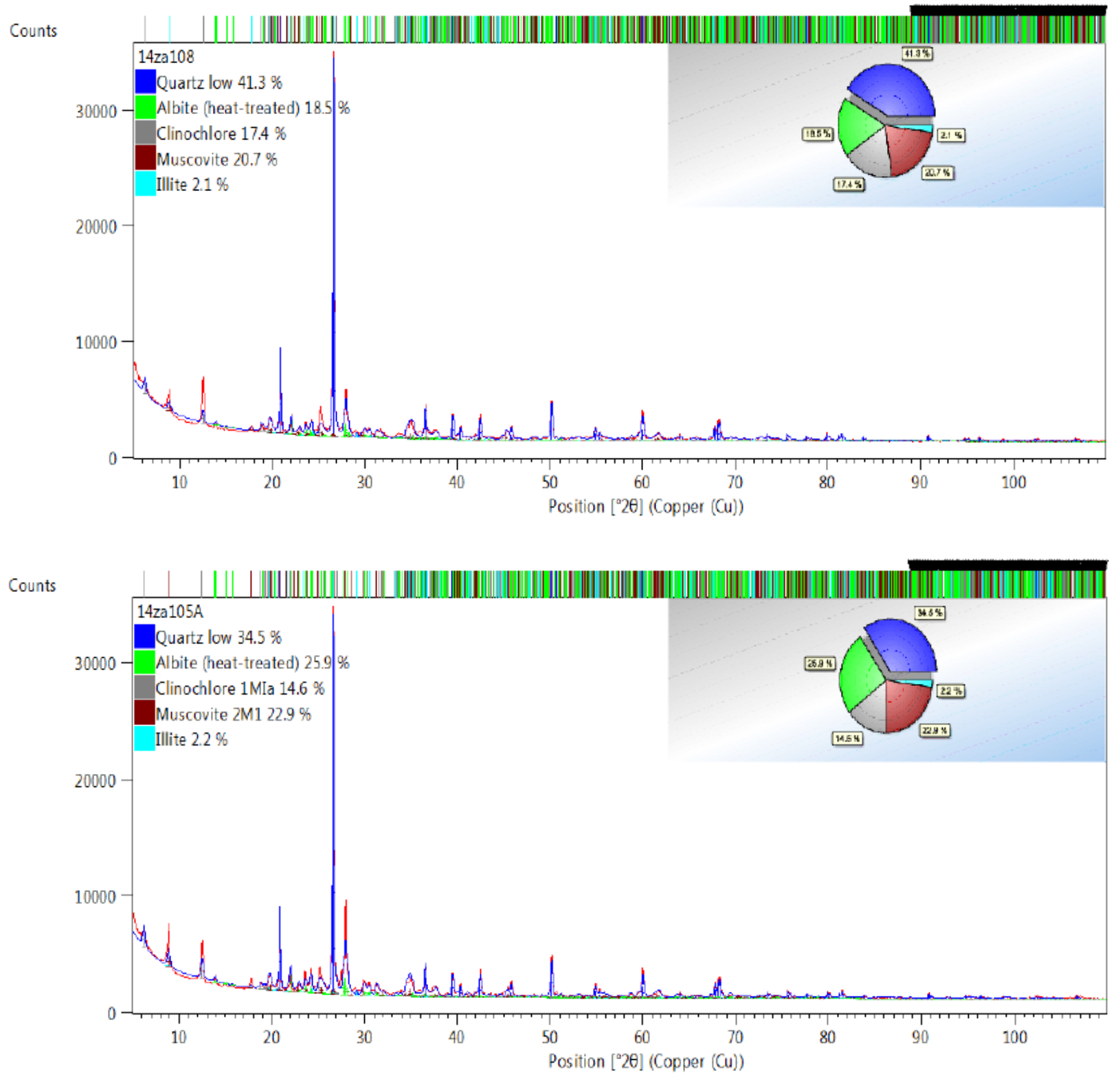
Counts

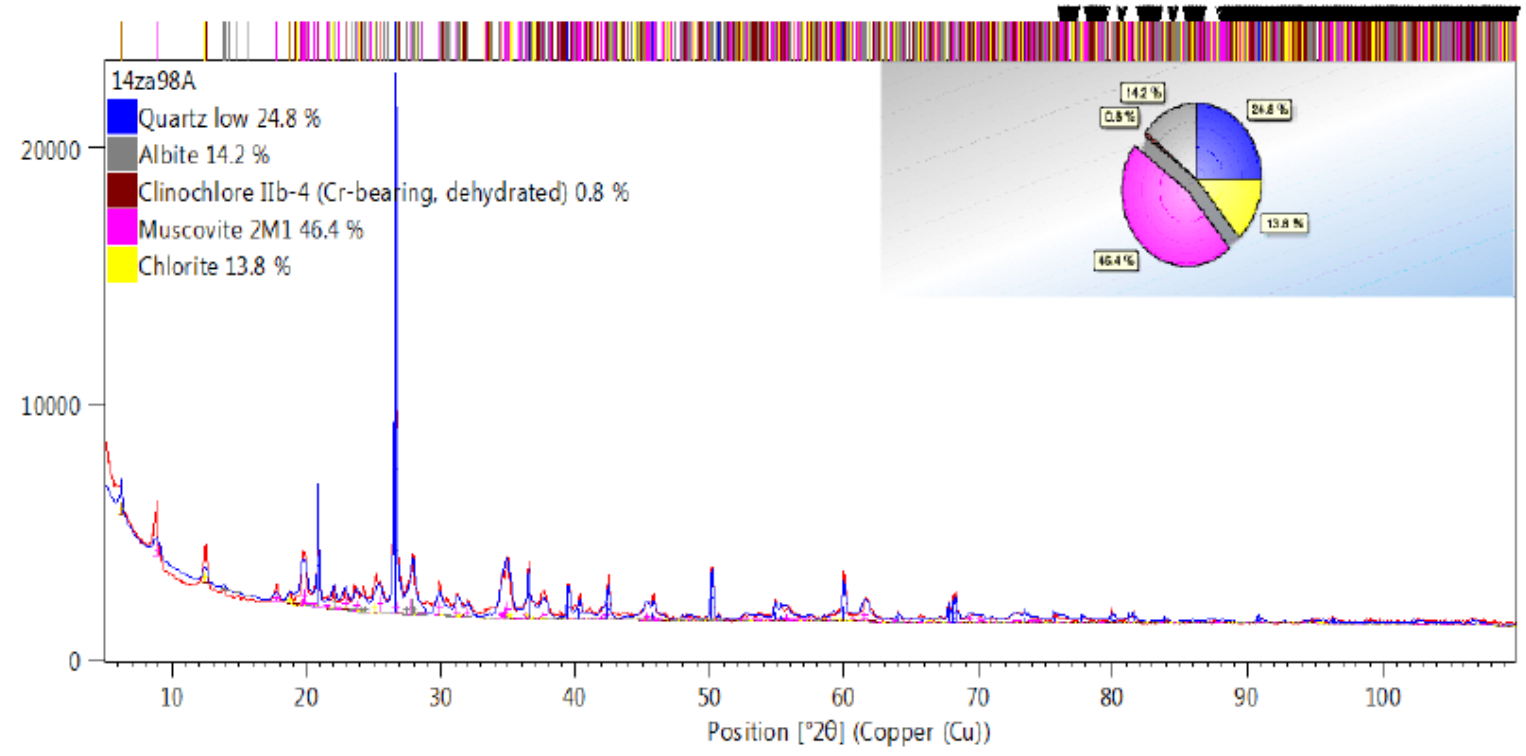

Counts

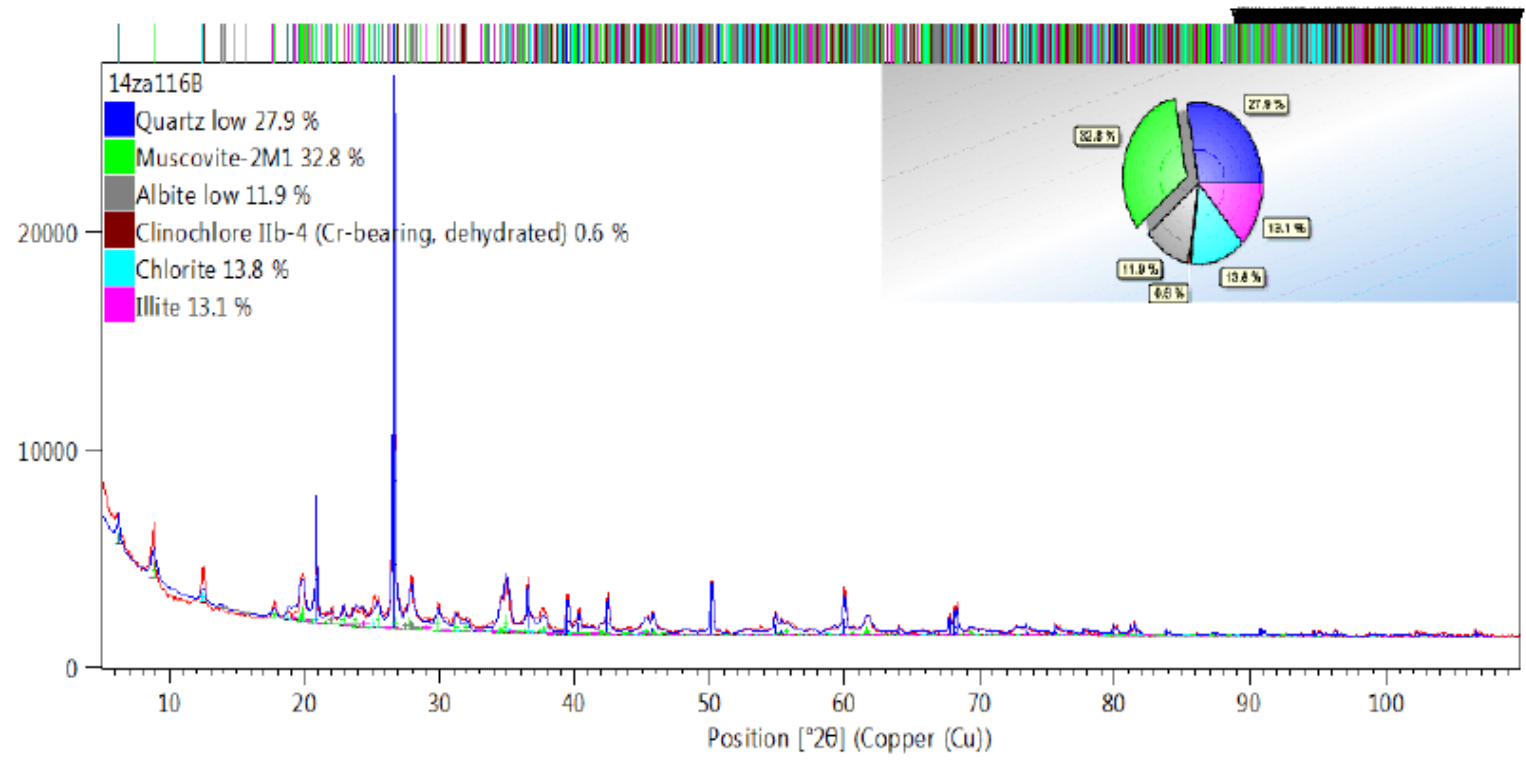



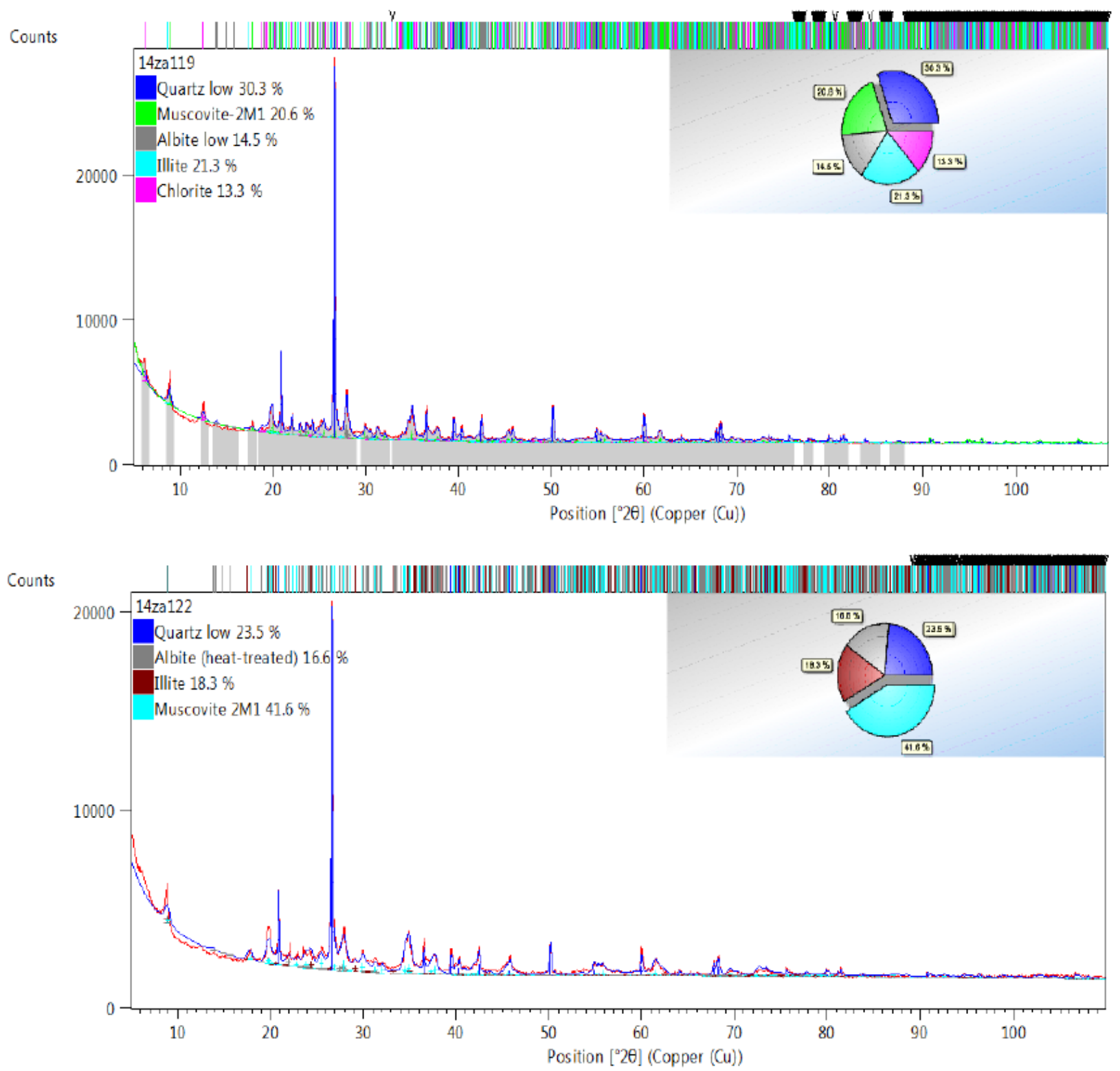


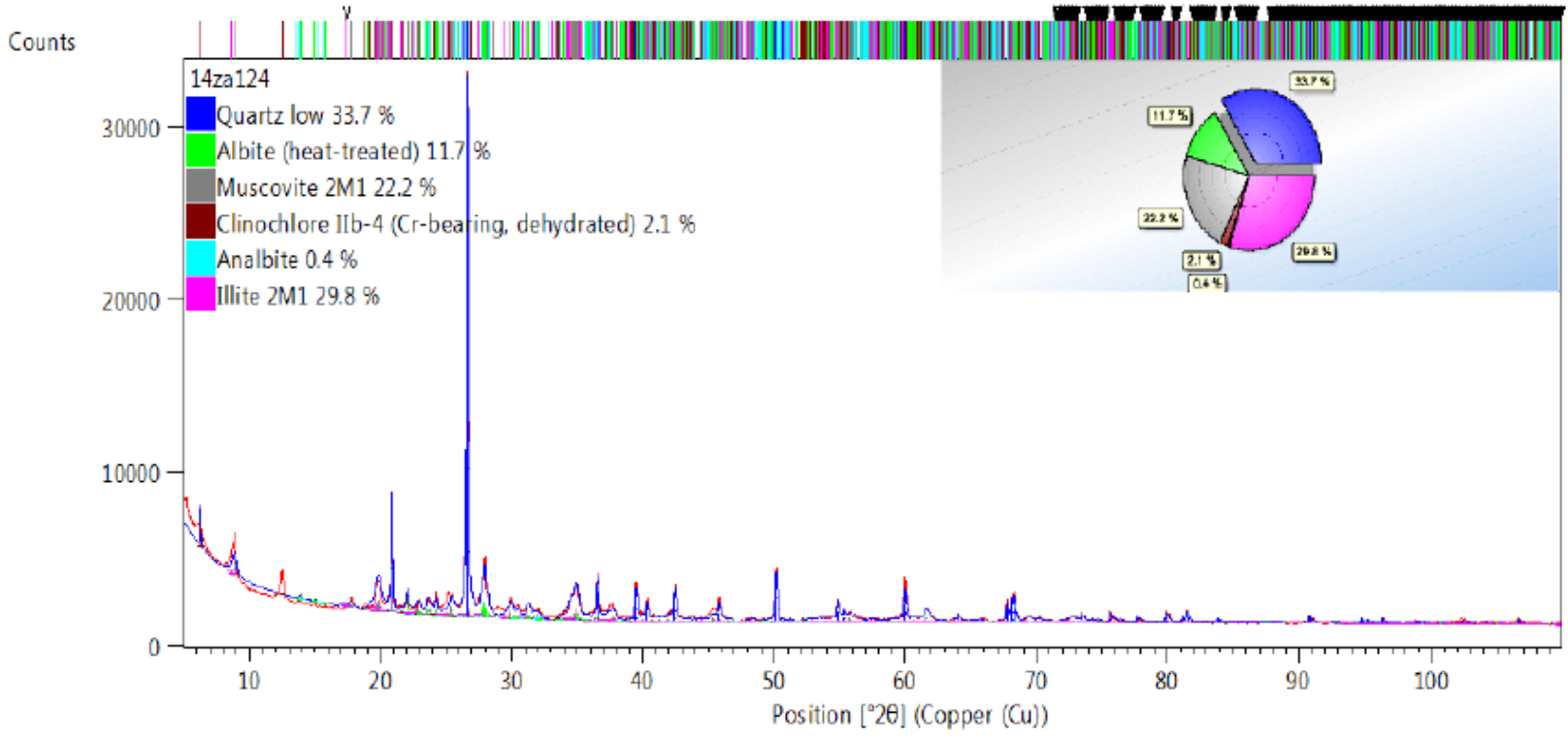

\section{Appendix II}

\section{Major Elements}

\section{Ripon Subbasin}

\begin{tabular}{|c|c|c|c|c|c|c|c|}
\hline Subbasin & Ripon & Ripon & Ripon & Ripon & Ripon & Ripon & Ripon \\
\hline Formation & Balfour & Balfour & Balfour & Balfour & Koonap & Koonap & $\begin{array}{l}\text { Waterfor } \\
\text { d }\end{array}$ \\
\hline $\begin{array}{l}\text { Sample } \\
\text { name }\end{array}$ & 14ZA160b & 14ZA161c & $\begin{array}{l}\text { 14ZA168 } \\
\text { b }\end{array}$ & $\begin{array}{l}\text { 14ZA162 } \\
b\end{array}$ & 14ZA163 & 14ZA159 & 14ZA164 \\
\hline SiO2 \% & 57.5266 & 64.5558 & 65.17 & 69.3838 & 65.518 & 67.790 & 62.031 \\
\hline TiO2 \% & 0.8976 & 0.6956 & 0.7346 & 0.5978 & 0.662 & 0.713 & 0.817 \\
\hline Al203 \% & 22.3696 & 17.21 & 17.0218 & 15.2634 & 17.631 & 17.346 & 18.367 \\
\hline Fe2O3 \% & 8.9696 & 6.8222 & 6.0076 & 5.8058 & 7.802 & 6.292 & 6.870 \\
\hline $\mathrm{MnO} \%$ & 0.031 & 0.0944 & 0.0874 & 0.0664 & 0.078 & 0.065 & 0.091 \\
\hline MgO \% & 1.6834 & 1.6804 & 1.8808 & 1.5534 & 1.808 & 1.898 & 1.935 \\
\hline $\mathrm{CaO} \%$ & 0.1858 & 1.1528 & 1.0904 & 0.6138 & 0.773 & 1.302 & 2.617 \\
\hline $\mathrm{Na20} \%$ & 0.1436 & 0.8976 & 1.6498 & 0.5268 & 0.640 & 1.009 & 1.845 \\
\hline K2O \% & 7.0652 & 4.6666 & 4.2462 & 4.2272 & 4.404 & 4.257 & 4.055 \\
\hline P2O5 \% & 0.0292 & 0.1474 & 0.1352 & 0.09 & 0.142 & 0.127 & 0.167 \\
\hline $\mathrm{CIA}$ & 73.12513 & 66.61881 & 64.68658 & 69.94694 & 70.932 & 66.766 & 60.124 \\
\hline ICV & 0.848303 & 0.93025 & 0.922159 & 0.877341 & 0.917 & 0.896 & 0.993 \\
\hline Subbasin & Ripon & Ripon & Ripon & Ripon & Ripon & Ripon & Ripon \\
\hline Formation & Waterford & $\begin{array}{l}\text { Fort } \\
\text { Brown }\end{array}$ & Ripon & Ripon & Ripon & Ripon & Ripon \\
\hline $\begin{array}{l}\text { Sample } \\
\text { name }\end{array}$ & 14IZA165 & 14IZA157 & 14ZA156 & 14IZA155 & 14IZA153 & 14IZA152 & 14IZA151 \\
\hline
\end{tabular}




\begin{tabular}{|c|c|c|c|c|c|c|c|}
\hline SiO2 \% & 66.628 & 62.739 & 67.955 & 60.768 & 62.567 & 62.982 & 63.667 \\
\hline TiO2 \% & 0.641 & 0.758 & 0.763 & 0.767 & 0.615 & 0.667 & 0.631 \\
\hline Al203 \% & 16.602 & 20.130 & 17.555 & 21.375 & 20.024 & 19.705 & 19.445 \\
\hline Fe2O3 \% & 7.355 & 6.832 & 6.252 & 7.922 & 7.549 & 7.225 & 6.191 \\
\hline MnO \% & 0.076 & 0.037 & 0.040 & 0.062 & 0.062 & 0.075 & 0.018 \\
\hline MgO \% & 2.119 & 1.740 & 1.595 & 2.248 & 2.119 & 2.091 & 1.628 \\
\hline $\mathrm{CaO} \%$ & 0.926 & 0.490 & 0.884 & 0.870 & 0.747 & 0.854 & 0.400 \\
\hline $\mathrm{Na2O} \%$ & 1.239 & 1.338 & 2.843 & 0.825 & 1.046 & 0.826 & 1.682 \\
\hline K2O \% & 4.253 & 4.399 & 2.851 & 5.107 & 5.004 & 4.669 & 4.885 \\
\hline P2O5 \% & 0.103 & 0.199 & 0.209 & 0.168 & 0.142 & 0.166 & 0.107 \\
\hline $\mathrm{CIA}$ & 66.604 & 71.937 & 65.197 & 71.627 & 70.214 & 71.215 & 68.888 \\
\hline ICV & 1.000 & 0.775 & 0.867 & 0.833 & 0.856 & 0.833 & 0.794 \\
\hline Subbasin & Ripon & Ripon & Ripon & Ripon & Ripon & Ripon & Ripon \\
\hline Formation & Ripon & Ripon & Ripon & Ripon & Collingham & Whitehill & $\begin{array}{l}\text { Prince } \\
\text { Albert }\end{array}$ \\
\hline $\begin{array}{l}\text { Sample } \\
\text { name }\end{array}$ & $14 \mid Z A 150$ & 14IZA149 & $14 \mid Z A 148$ & 14IZA146 & 14IZA145 & $\begin{array}{l}\text { 14IZA144 } \\
\text { A }\end{array}$ & 14ZA147 \\
\hline SiO2 \% & 61.812 & 63.657 & 66.466 & 63.152 & 70.095 & 90.740 & 63.000 \\
\hline TiO2 \% & 0.680 & 0.535 & 0.560 & 0.650 & 0.587 & 0.407 & 0.742 \\
\hline Al203 \% & 19.590 & 18.855 & 18.584 & 19.397 & 16.069 & 3.332 & 19.878 \\
\hline Fe2O3 \% & 8.277 & 6.174 & 6.233 & 6.218 & 5.466 & 0.240 & 11.217 \\
\hline MnO \% & 0.042 & 0.035 & 0.011 & 0.020 & 0.036 & -0.011 & 0.054 \\
\hline MgO \% & 2.347 & 1.890 & 1.924 & 1.369 & 1.264 & 0.269 & 1.267 \\
\hline $\mathrm{CaO} \%$ & 0.542 & 0.519 & 0.343 & 0.314 & 0.285 & 0.222 & 0.241 \\
\hline $\mathrm{Na2O} \%$ & 1.054 & 1.516 & 0.657 & 0.556 & 0.618 & 0.314 & 0.241 \\
\hline K2O \% & 4.849 & 4.947 & 4.690 & 4.817 & 3.579 & 0.650 & 3.200 \\
\hline P2O5 \% & 0.273 & 0.074 & 0.111 & 0.129 & 0.073 & 0.077 & 0.198 \\
\hline CIA & 71.087 & 68.199 & 73.269 & 74.330 & 74.816 & 67.236 & 82.224 \\
\hline ICV & 0.908 & 0.828 & 0.776 & 0.719 & 0.737 & 0.627 & 0.853 \\
\hline
\end{tabular}

\section{Laingsburg Subbasin}

\begin{tabular}{|c|c|c|c|c|c|c|c|}
\hline Subbasin & Laingsburg & Laingsburg & Laingsburg & Laingsburg & Laingsburg & Laingsburg & Laingsburg \\
\hline Formation & Abrahamskral & Abrahamskral & Abrahamskral & Waterford & Waterford & Waterford & Laingsburg \\
\hline Sample name & 14ZA129b & 14ZA130b & 14ZA130c & 14ZA124 & 14ZA122 & 14ZA119 & 14ZA116b \\
\hline $\mathrm{SiO} 2 \%$ & 60.7824 & 66.856 & 66.4576 & 66.041 & 61.656 & 61.826 & 60.077 \\
\hline TiO2 \% & 0.7876 & 0.7094 & 0.7172 & 0.791 & 0.700 & 0.707 & 0.740 \\
\hline Al203 \% & 19.7224 & 16.3438 & 16.9042 & 17.792 & 19.576 & 18.749 & 19.173 \\
\hline Fe2O3 \% & 8.0566 & 6.224 & 5.408 & 6.733 & 8.765 & 8.048 & 7.731 \\
\hline MnO \% & 0.0778 & 0.0498 & 0.0338 & 0.074 & 0.099 & 0.074 & 0.076 \\
\hline MgO \% & 2.3016 & 1.677 & 1.6854 & 1.788 & 2.551 & 1.989 & 2.295 \\
\hline
\end{tabular}




\begin{tabular}{|c|c|c|c|c|c|c|c|}
\hline $\mathrm{CaO} \%$ & 0.8124 & 0.9078 & 1.085 & 1.057 & 0.992 & 1.002 & 0.824 \\
\hline $\mathrm{Na} 2 \mathrm{O} \%$ & 1.0006 & 1.5242 & 1.5504 & 1.401 & 1.011 & 1.557 & 0.969 \\
\hline K2O \% & 4.7382 & 4.1376 & 4.6862 & 3.932 & 5.314 & 3.699 & 4.307 \\
\hline P2O5 \% & 0.141 & 0.1224 & 0.2278 & 0.147 & 0.116 & 0.256 & 0.158 \\
\hline CIA & 70.50262 & 65.42724 & 63.79045 & 67.716 & 67.985 & 69.092 & 71.201 \\
\hline ICV & 0.901249 & 0.93184 & 0.897173 & 0.887 & 0.993 & 0.911 & 0.884 \\
\hline Subbasin & Laingsburg & Laingsburg & Laingsburg & Laingsburg & Laingsburg & Laingsburg & Laingsburg \\
\hline Formation & Laingsburg & Laingsburg & Laingsburg & Vischkuil & Collingham & Collingham & Whitehill \\
\hline Sample name & 14ZA98a & 14ZA105a & 14ZA108 & 14ZA105B & 14IZA106 & 14ZA99B & 14IZA107 \\
\hline $\mathrm{SiO2} \%$ & 60.120 & 67.028 & 67.477 & 68.404 & 75.653 & 63.715 & 69.386 \\
\hline TiO2 \% & 0.770 & 0.786 & 0.649 & 0.800 & 0.514 & 0.729 & 0.698 \\
\hline Al2O3 \% & 19.843 & 15.869 & 15.332 & 20.477 & 14.662 & 20.332 & 17.579 \\
\hline Fe2O3 \% & 8.118 & 5.865 & 7.313 & 6.432 & 2.690 & 4.703 & 2.136 \\
\hline MnO \% & 0.064 & 0.071 & 0.070 & 0.019 & 0.051 & 0.000 & -0.010 \\
\hline MgO \% & 2.546 & 1.959 & 1.932 & 1.877 & 0.767 & 1.742 & 1.113 \\
\hline $\mathrm{CaO} \%$ & 0.967 & 1.013 & 0.259 & 0.478 & 0.238 & 0.339 & 0.148 \\
\hline $\mathrm{Na} 20 \%$ & 1.004 & 2.548 & 2.336 & 1.230 & 2.967 & 1.992 & 2.129 \\
\hline K2O \% & 5.006 & 3.333 & 2.754 & 5.185 & 2.768 & 5.236 & 3.732 \\
\hline P2O5 \% & 0.140 & 0.193 & 0.156 & 0.171 & 0.148 & 0.111 & 0.065 \\
\hline CIA & 69.208 & 62.205 & 67.761 & 70.656 & 63.828 & 68.016 & 69.238 \\
\hline ICV & 0.931 & 0.982 & 0.999 & 0.782 & 0.682 & 0.725 & 0.566 \\
\hline Subbasin & Laingsburg & Laingsburg & Laingsburg & & & & \\
\hline Formation & Whitehill & Prince Albert & Prince Albert & & & & \\
\hline Sample name & 14ZA102 & 14ZA103a & 14ZA103d & & & & \\
\hline SiO2 \% & 69.716 & 66.134 & 77.049 & & & & \\
\hline TiO2 \% & 0.770 & 0.742 & 0.404 & & & & \\
\hline Al203 \% & 16.603 & 18.226 & 14.174 & & & & \\
\hline Fe2O3\% & 6.522 & 6.348 & 2.537 & & & & \\
\hline $\mathrm{MnO} \%$ & -0.007 & -0.002 & 0.023 & & & & \\
\hline $\mathrm{MgO} \%$ & 0.946 & 1.213 & 0.754 & & & & \\
\hline $\mathrm{CaO} \%$ & 0.107 & 0.497 & 0.325 & & & & \\
\hline $\mathrm{Na} 2 \mathrm{O} \%$ & 2.163 & 2.365 & 0.669 & & & & \\
\hline $\mathrm{K} 2 \mathrm{O} \%$ & 3.783 & 3.466 & 2.393 & & & & \\
\hline P2O5 \% & 0.253 & 0.242 & 0.094 & & & & \\
\hline CIA & 67.906 & 68.076 & 76.806 & & & & \\
\hline ICV & 0.860 & 0.803 & 0.501 & & & & \\
\hline
\end{tabular}




\section{Appendix III}

\section{Trace Elements}

Ripon Subbasin

\begin{tabular}{|c|c|c|c|c|c|c|c|}
\hline Subbasin & Ripon & Ripon & Ripon & Ripon & Ripon & Ripon & Ripon \\
\hline Formation & Balfour & Balfour & Balfour & Balfour & Koonap & Koonap & Waterford \\
\hline Sample & 14ZA168 & 14ZA160 & 14ZA161 & 14ZA162B & 14ZA163 & 14ZA159 & 14ZA164 \\
\hline La ppm & 42.06 & 32.32 & 46.40 & 23.94 & 33.766 & 36.712 & 43.537 \\
\hline Ce ppm & 73.17 & 48.83 & 78.53 & 35.78 & 90.357 & 71.272 & 88.077 \\
\hline Pr ppm & 9.58 & 5.66 & 11.06 & 5.61 & 8.207 & 8.660 & 10.641 \\
\hline Nd ppm & 35.47 & 19.15 & 42.25 & 20.85 & 31.518 & 32.636 & 40.337 \\
\hline Sm ppm & 7.32 & 3.53 & 8.91 & 4.36 & 6.741 & 6.945 & 8.392 \\
\hline Eu ppm & 1.37 & 0.70 & 1.65 & 0.80 & 1.268 & 1.258 & 1.616 \\
\hline Gd ppm & 6.21 & 3.00 & 7.84 & 3.83 & 6.051 & 5.880 & 7.225 \\
\hline Tb ppm & 1.00 & 0.57 & 1.27 & 0.66 & 1.001 & 0.945 & 1.121 \\
\hline Dy ppm & 5.83 & 3.86 & 7.68 & 4.19 & 6.076 & 5.754 & 6.624 \\
\hline Ho ppm & 1.14 & 0.89 & 1.52 & 0.87 & 1.222 & 1.131 & 1.320 \\
\hline Er ppm & 3.06 & 2.83 & 4.18 & 2.42 & 3.297 & 3.071 & 3.484 \\
\hline Tm ppm & 0.45 & 0.47 & 0.62 & 0.37 & 0.493 & 0.445 & 0.498 \\
\hline Yb ppm & 2.74 & 3.26 & 3.69 & 2.33 & 3.042 & 2.749 & 3.095 \\
\hline Lu ppm & 0.43 & 0.53 & 0.58 & 0.35 & 0.477 & 0.428 & 0.472 \\
\hline Ba ppm & 737 & 885 & 804 & 715 & 665.793 & 814.091 & 767.904 \\
\hline Th ppm & 16.23 & 22.78 & 19.20 & 16.27 & 19.445 & 16.402 & 19.741 \\
\hline Nb ppm & 13.42 & 17.39 & 14.59 & 12.21 & 13.289 & 14.438 & 15.948 \\
\hline Y ppm & 29.27 & 22.69 & 40.44 & 22.31 & 32.339 & 29.021 & 34.182 \\
\hline Hf ppm & 3.74 & 6.06 & 4.82 & 3.73 & 4.487 & 3.557 & 5.239 \\
\hline Ta ppm & 1.09 & 1.42 & 1.17 & 0.98 & 1.096 & 1.138 & 1.280 \\
\hline U ppm & 2.97 & 5.33 & 3.33 & 2.24 & 2.963 & 3.606 & 4.225 \\
\hline Pb ppm & 21.36 & 24.28 & 23.24 & 16.83 & 19.595 & 20.046 & 36.914 \\
\hline Rb ppm & 191.6 & 317.2 & 217.1 & 240.0 & 227.369 & 206.275 & 185.210 \\
\hline Cs ppm & 11.10 & 15.18 & 16.00 & 22.68 & 16.783 & 13.407 & 10.467 \\
\hline Sr ppm & 135 & 42 & 151 & 109 & 84.750 & 267.275 & 891.042 \\
\hline Sc ppm & 14.8 & 20.3 & 15.9 & 13.0 & 16.885 & 15.824 & 15.016 \\
\hline Zr ppm & 128 & 211 & 164 & 120 & 147.613 & 122.273 & 184.419 \\
\hline Th/Sc & 17.264 & 20.897 & 13.568 & 10.580 & 13.547 & 15.385 & 17.695 \\
\hline Zr/Sc & 12.202 & 2.759 & 9.428 & 4.795 & 5.050 & 19.935 & 85.131 \\
\hline Th/U & 7.425 & 10.080 & 12.117 & 11.308 & 10.896 & 7.947 & 10.422 \\
\hline $\mathbf{E u} / \mathbf{E u} *$ & 0.113 & 0.216 & 0.101 & 0.114 & 0.151 & 0.088 & 0.037 \\
\hline $\mathrm{Ce} / \mathrm{Ce}^{*}$ & 1.078 & 0.190 & 0.735 & 0.438 & 0.416 & 1.803 & 6.269 \\
\hline Subbasin & Ripon & Ripon & Ripon & Ripon & Ripon & Ripon & Ripon \\
\hline Formation & Waterford & Fort Brown & Ripon & Ripon & Ripon & Ripon & Ripon \\
\hline Sample & 14ZA165 & 14ZA157 & 14ZA156 & 14ZA155 & 14ZA153 & 14ZA152 & 14ZA151 \\
\hline La ppm & 29.185 & 43.502 & 35.167 & 37.393 & 27.832 & 41.017 & 19.216 \\
\hline Ce ppm & 53.774 & 80.623 & 59.338 & 47.236 & 44.399 & 70.014 & 25.701 \\
\hline Pr ppm & 7.275 & 10.532 & 9.911 & 8.892 & 8.076 & 10.330 & 5.120 \\
\hline Nd ppm & 27.637 & 39.728 & 38.754 & 33.895 & 32.362 & 38.804 & 20.632 \\
\hline
\end{tabular}




\begin{tabular}{|c|c|c|c|c|c|c|c|}
\hline Sm ppm & 6.012 & 8.175 & 8.570 & 7.218 & 7.201 & 7.868 & 5.156 \\
\hline Eu ppm & 1.145 & 1.396 & 1.700 & 1.355 & 1.264 & 1.239 & 1.021 \\
\hline Gd ppm & 5.127 & 6.911 & 7.357 & 5.957 & 6.262 & 6.361 & 5.025 \\
\hline Tb ppm & 0.847 & 1.084 & 1.215 & 0.963 & 0.994 & 0.992 & 0.855 \\
\hline Dy ppm & 5.151 & 6.362 & 7.145 & 5.777 & 5.899 & 5.841 & 5.576 \\
\hline Ho ppm & 1.057 & 1.267 & 1.413 & 1.153 & 1.175 & 1.159 & 1.166 \\
\hline Er ppm & 2.814 & 3.374 & 3.702 & 3.102 & 3.197 & 3.095 & 3.240 \\
\hline Tm ppm & 0.417 & 0.481 & 0.541 & 0.462 & 0.470 & 0.455 & 0.476 \\
\hline Yb ppm & 2.616 & 3.006 & 3.259 & 2.851 & 2.960 & 2.897 & 3.025 \\
\hline Lu ppm & 0.406 & 0.465 & 0.484 & 0.442 & 0.476 & 0.445 & 0.467 \\
\hline Ba ppm & 678.493 & 870.076 & 601.936 & 778.845 & 700.694 & 806.010 & 732.031 \\
\hline Th ppm & 16.285 & 17.962 & 16.995 & 17.998 & 16.814 & 17.471 & 17.820 \\
\hline Nb ppm & 13.699 & 14.503 & 14.060 & 14.161 & 11.931 & 12.482 & 12.860 \\
\hline Y ppm & 26.434 & 33.643 & 36.306 & 29.566 & 31.154 & 30.104 & 29.814 \\
\hline Hf ppm & 3.976 & 4.136 & 4.439 & 3.648 & 3.770 & 3.751 & 4.671 \\
\hline Ta ppm & 1.136 & 1.169 & 1.152 & 1.141 & 0.968 & 1.027 & 1.109 \\
\hline U ppm & 3.183 & 4.036 & 4.500 & 3.563 & 3.820 & 4.459 & 4.847 \\
\hline Pb ppm & 18.681 & 18.101 & 19.885 & 33.540 & 21.960 & 28.803 & 25.648 \\
\hline Rb ppm & 204.355 & 209.261 & 131.547 & 249.383 & 252.858 & 218.366 & 241.529 \\
\hline Cs ppm & 11.102 & 11.040 & 6.755 & 13.582 & 14.385 & 12.571 & 15.128 \\
\hline Sr ppm & 110.969 & 69.582 & 129.861 & 54.301 & 63.543 & 64.006 & 125.731 \\
\hline Sc ppm & 14.772 & 17.336 & 13.852 & 19.107 & 17.693 & 17.534 & 16.115 \\
\hline Zr ppm & 134.710 & 143.538 & 151.949 & 122.466 & 125.013 & 127.738 & 155.609 \\
\hline Th/Sc & 18.408 & 18.955 & 19.475 & 18.362 & 17.578 & 17.371 & 15.966 \\
\hline $\mathrm{Zr} / \mathrm{Sc}$ & 9.996 & 6.303 & 19.226 & 3.998 & 4.417 & 5.092 & 8.311 \\
\hline Th/U & 7.318 & 7.573 & 7.802 & 6.670 & 7.112 & 7.354 & 9.746 \\
\hline $\mathbf{E u} / \mathbf{E u} *$ & 0.121 & 0.173 & 0.099 & 0.234 & 0.199 & 0.194 & 0.115 \\
\hline $\mathrm{Ce} / \mathrm{Ce}^{*}$ & 0.861 & 0.526 & 1.560 & 0.361 & 0.395 & 0.450 & 0.666 \\
\hline Subbasin & Ripon & Ripon & Ripon & Ripon & Ripon & Ripon & Ripon \\
\hline Formation & Ripon & Ripon & Ripon & Ripon & Collingham & Whitehill & $\begin{array}{l}\text { Prince } \\
\text { Albert }\end{array}$ \\
\hline Sample & 14ZA150 & 14ZA149 & 14ZA148 & 14ZA146 & 14ZA145 & 14ZA144A & 14ZA147 \\
\hline La ppm & 21.495 & 28.819 & 35.186 & 42.183 & 40.721 & 28.825 & 57.146 \\
\hline Ce ppm & 31.581 & 44.365 & 57.746 & 77.446 & 80.769 & 56.820 & 112.498 \\
\hline Pr ppm & 5.858 & 7.288 & 8.170 & 8.839 & 10.306 & 6.419 & 15.357 \\
\hline Nd ppm & 23.712 & 28.924 & 31.367 & 32.411 & 39.101 & 23.334 & 60.539 \\
\hline Sm ppm & 5.553 & 7.161 & 7.768 & 6.999 & 7.850 & 4.332 & 12.242 \\
\hline Eu ppm & 1.049 & 1.277 & 1.384 & 1.280 & 1.121 & 0.670 & 2.178 \\
\hline Gd ppm & 5.123 & 7.139 & 7.551 & 6.472 & 6.886 & 3.955 & 9.954 \\
\hline Tb ppm & 0.860 & 1.211 & 1.297 & 1.071 & 1.123 & 0.705 & 1.464 \\
\hline Dy ppm & 5.383 & 7.599 & 7.881 & 6.577 & 6.954 & 4.672 & 8.659 \\
\hline Ho ppm & 1.107 & 1.547 & 1.538 & 1.368 & 1.399 & 0.996 & 1.727 \\
\hline Er ppm & 3.093 & 4.246 & 4.040 & 3.766 & 3.888 & 2.845 & 4.616 \\
\hline Tm ppm & 0.458 & 0.626 & 0.593 & 0.559 & 0.571 & 0.414 & 0.675 \\
\hline Yb ppm & 2.918 & 3.926 & 3.801 & 3.641 & 3.646 & 2.682 & 4.177 \\
\hline Lu ppm & 0.458 & 0.613 & 0.598 & 0.574 & 0.581 & 0.425 & 0.626 \\
\hline Ba ppm & 597.860 & 585.224 & 699.872 & 879.950 & 663.886 & 183.514 & 639.397 \\
\hline Th ppm & 17.638 & 17.911 & 17.517 & 18.859 & 17.504 & 10.998 & 17.979 \\
\hline Nb ppm & 13.221 & 13.574 & 13.118 & 13.186 & 12.575 & 7.609 & 12.157 \\
\hline
\end{tabular}




\begin{tabular}{|c|c|c|c|c|c|c|c|}
\hline Y ppm & 31.133 & 42.433 & 40.379 & 34.528 & 38.003 & 28.561 & 44.869 \\
\hline Hf ppm & 3.410 & 5.045 & 4.566 & 4.415 & 4.910 & 3.406 & 4.604 \\
\hline Ta ppm & 1.015 & 1.012 & 0.995 & 1.052 & 1.039 & 0.606 & 0.954 \\
\hline U ppm & 4.722 & 6.598 & 6.774 & 4.078 & 4.889 & 5.809 & 3.786 \\
\hline Pb ppm & 21.512 & 26.491 & 23.358 & 30.859 & 23.771 & 38.296 & 12.888 \\
\hline Rb ppm & 266.952 & 276.968 & 248.293 & 229.050 & 178.569 & 37.829 & 159.786 \\
\hline Cs ppm & 13.056 & 21.516 & 16.095 & 18.167 & 19.161 & 3.786 & 9.320 \\
\hline Sr ppm & 84.656 & 150.799 & 66.426 & 46.698 & 51.251 & 176.428 & 89.355 \\
\hline Sc ppm & 18.217 & 13.832 & 14.873 & 17.918 & 13.742 & 9.272 & 19.776 \\
\hline Zr ppm & 114.736 & 173.550 & 155.154 & 153.902 & 177.282 & 151.013 & 149.591 \\
\hline Th/Sc & 20.447 & 12.873 & 15.427 & 12.608 & 9.319 & 9.991 & 17.144 \\
\hline Zr/Sc & 6.484 & 7.009 & 4.127 & 2.570 & 2.675 & 46.595 & 9.587 \\
\hline Th/U & 5.611 & 13.482 & 10.057 & 12.207 & 19.023 & 15.115 & 8.726 \\
\hline $\mathbf{E u} / \mathbf{E u} *$ & 0.185 & 0.086 & 0.147 & 0.211 & 0.144 & 0.057 & 0.171 \\
\hline $\mathrm{Ce} / \mathrm{Ce} *$ & 0.605 & 0.532 & 0.331 & 0.207 & 0.201 & 3.792 & 0.784 \\
\hline
\end{tabular}

\section{Laingsburg Subbasin}

\begin{tabular}{|c|c|c|c|c|c|c|c|}
\hline Subbasin & Laingsburg & Laingsburg & Laingsburg & $\begin{array}{l}\text { Laingsbur } \\
\text { g }\end{array}$ & Laingsburg & Laingsburg & Laingsburg \\
\hline Formation & Abrahamskral & Abrahamskral & Abrahamskral & Waterford & Waterford & Waterford & Laingsburg \\
\hline Sample & 14ZA130C & 14ZA129B & 14ZA130B & 14ZA124 & 14ZA122 & 14ZA119 & 14ZA116B \\
\hline La ppm & 73.64 & 36.40 & 38.83 & 67.008 & 17.927 & 37.502 & 25.643 \\
\hline Ce ppm & 56.21 & 71.93 & 67.13 & 111.257 & 80.749 & 75.509 & 48.344 \\
\hline Pr ppm & 19.64 & 8.83 & 8.30 & 14.713 & 6.250 & 9.501 & 7.291 \\
\hline Nd ppm & 76.78 & 32.75 & 30.30 & 53.304 & 25.218 & 36.490 & 28.437 \\
\hline Sm ppm & 16.61 & 6.99 & 6.16 & 9.593 & 6.024 & 7.860 & 6.778 \\
\hline Eu ppm & 3.10 & 1.32 & 1.16 & 1.846 & 1.249 & 1.570 & 1.285 \\
\hline Gd ppm & 13.87 & 5.88 & 5.50 & 8.189 & 5.109 & 6.915 & 5.972 \\
\hline Tb ppm & 2.18 & 0.96 & 0.92 & 1.282 & 0.866 & 1.097 & 1.015 \\
\hline Dy ppm & 12.15 & 5.56 & 5.70 & 7.683 & 5.210 & 6.363 & 6.052 \\
\hline Ho ppm & 2.34 & 1.11 & 1.15 & 1.513 & 1.040 & 1.245 & 1.202 \\
\hline Er ppm & 6.01 & 3.00 & 3.10 & 4.036 & 2.880 & 3.379 & 3.318 \\
\hline Tm ppm & 0.86 & 0.45 & 0.46 & 0.589 & 0.429 & 0.496 & 0.495 \\
\hline Yb ppm & 5.02 & 2.79 & 2.84 & 3.595 & 2.663 & 3.107 & 3.137 \\
\hline Lu ppm & 0.72 & 0.43 & 0.43 & 0.552 & 0.418 & 0.491 & 0.480 \\
\hline Ba ppm & 533 & 608 & 500 & 484.715 & 573.825 & 661.982 & 649.786 \\
\hline Th ppm & 18.36 & 17.23 & 15.75 & 17.178 & 16.376 & 16.522 & 18.385 \\
\hline Nb ppm & 16.00 & 14.79 & 13.97 & 14.936 & 12.971 & 13.369 & 13.981 \\
\hline Y ppm & 59.42 & 29.09 & 31.03 & 41.984 & 27.125 & 32.402 & 30.918 \\
\hline Hf ppm & 6.17 & 3.71 & 3.64 & 4.457 & 3.096 & 3.735 & 3.703 \\
\hline Ta ppm & 1.27 & 1.22 & 1.11 & 1.231 & 1.026 & 1.078 & 1.124 \\
\hline U ppm & 4.63 & 2.85 & 3.43 & 3.799 & 2.464 & 3.499 & 3.975 \\
\hline Pb ppm & 25.56 & 30.22 & 30.60 & 19.811 & 42.491 & 33.547 & 23.218 \\
\hline Rb ppm & 211.5 & 205.9 & 198.1 & 183.079 & 276.964 & 179.632 & 215.579 \\
\hline Cs ppm & 11.62 & 13.73 & 12.24 & 10.388 & 22.459 & 10.720 & 13.135 \\
\hline Sr ppm & 182 & 70 & 136 & 72.678 & 91.768 & 103.859 & 81.529 \\
\hline Sc ppm & 13.0 & 17.1 & 14.4 & 16.322 & 17.845 & 17.711 & 18.502 \\
\hline
\end{tabular}




\begin{tabular}{|c|c|c|c|c|c|c|c|}
\hline Zr ppm & 218 & 123 & 124 & 154.345 & 107.468 & 127.072 & 128.681 \\
\hline Th/Sc & 18.205 & 14.997 & 16.184 & 17.623 & 12.332 & 16.757 & 16.413 \\
\hline Zr/Sc & 15.642 & 5.109 & 11.128 & 6.996 & 4.086 & 9.689 & 6.207 \\
\hline $\mathbf{T h} / \mathbf{U}$ & 11.977 & 8.228 & 7.674 & 8.758 & 8.715 & 7.583 & 7.840 \\
\hline $\mathbf{E u} / \mathbf{E u} *$ & 0.065 & 0.183 & 0.111 & 0.154 & 0.180 & 0.154 & 0.181 \\
\hline $\mathrm{Ce} / \mathrm{Ce}^{*}$ & 1.059 & 0.460 & 0.999 & 0.563 & 0.394 & 0.859 & 0.547 \\
\hline Subbasin & Laingsburg & Laingsburg & Laingsburg & Laingsburg & Laingsburg & Laingsburg & Laingsburg \\
\hline Formation & Laingsburg & Laingsburg & Laingsburg & Vischkuil & Collingham & Collingham & Whitehill \\
\hline Sample & 14ZA98A & 14ZA105A & 14ZA108 & 14ZA105B & 14ZA106 & 14ZA99B & 14ZA107 \\
\hline La ppm & 36.818 & 32.568 & 37.824 & 42.214 & 45.739 & 41.745 & 43.487 \\
\hline Ce ppm & 45.750 & 64.421 & 75.882 & 85.349 & 87.962 & 86.323 & 89.840 \\
\hline Pr ppm & 9.249 & 8.810 & 9.094 & 9.974 & 10.318 & 10.517 & 10.297 \\
\hline Nd ppm & 35.100 & 34.732 & 33.486 & 35.814 & 36.866 & 40.094 & 35.633 \\
\hline Sm ppm & 7.546 & 7.960 & 6.483 & 7.049 & 6.202 & 8.061 & 5.127 \\
\hline Eu ppm & 1.480 & 1.562 & 0.911 & 1.194 & 1.000 & 1.135 & 0.728 \\
\hline Gd ppm & 6.375 & 7.023 & 5.449 & 5.657 & 4.520 & 6.423 & 3.623 \\
\hline Tb ppm & 1.057 & 1.179 & 0.896 & 0.919 & 0.773 & 1.093 & 0.688 \\
\hline Dy ppm & 6.448 & 7.078 & 5.490 & 5.731 & 4.939 & 6.728 & 4.665 \\
\hline Ho ppm & 1.264 & 1.387 & 1.093 & 1.160 & 1.006 & 1.366 & 1.026 \\
\hline Er ppm & 3.477 & 3.846 & 3.145 & 3.329 & 2.873 & 3.862 & 3.010 \\
\hline Tm ppm & 0.524 & 0.568 & 0.478 & 0.503 & 0.439 & 0.571 & 0.468 \\
\hline Yb ppm & 3.269 & 3.534 & 2.959 & 3.211 & 2.783 & 3.536 & 3.030 \\
\hline Lu ppm & 0.493 & 0.544 & 0.472 & 0.516 & 0.428 & 0.552 & 0.479 \\
\hline Ba ppm & 632.203 & 612.552 & 602.303 & 876.485 & 695.374 & 790.638 & 625.190 \\
\hline Th ppm & 18.796 & 18.095 & 15.573 & 19.601 & 13.049 & 19.410 & 17.762 \\
\hline Nb ppm & 14.658 & 16.581 & 12.686 & 15.945 & 13.561 & 15.514 & 16.515 \\
\hline Y ppm & 32.788 & 36.407 & 28.607 & 29.011 & 26.938 & 34.472 & 25.014 \\
\hline Hf ppm & 3.982 & 4.935 & 4.320 & 4.043 & 4.627 & 4.899 & 4.954 \\
\hline Ta ppm & 1.171 & 1.341 & 1.004 & 1.264 & 0.826 & 1.243 & 1.256 \\
\hline U ppm & 3.972 & 4.846 & 4.306 & 3.558 & 6.732 & 4.374 & 5.627 \\
\hline Pb ppm & 33.609 & 21.741 & 22.865 & 37.462 & 16.815 & 36.568 & 27.389 \\
\hline Rb ppm & 255.018 & 185.804 & 124.856 & 265.390 & 119.926 & 251.326 & 176.889 \\
\hline Cs ppm & 16.460 & 10.775 & 7.151 & 16.269 & 6.919 & 14.776 & 9.563 \\
\hline Sr ppm & 69.089 & 100.553 & 74.530 & 73.400 & 104.303 & 72.374 & 89.683 \\
\hline Sc ppm & 19.120 & 15.257 & 12.868 & 18.661 & 10.665 & 17.525 & 13.887 \\
\hline Zr ppm & 134.575 & 169.481 & 147.044 & 138.027 & 178.929 & 145.918 & 166.910 \\
\hline Th/Sc & 15.493 & 17.244 & 17.461 & 16.312 & 17.332 & 17.009 & 18.497 \\
\hline Zr/Sc & 4.197 & 9.332 & 10.423 & 4.512 & 15.074 & 4.898 & 9.378 \\
\hline $\mathbf{T h} / \mathbf{U}$ & 8.686 & 9.828 & 8.421 & 8.462 & 10.323 & 8.579 & 9.024 \\
\hline $\mathbf{E u} / \mathbf{E u} *$ & 0.198 & 0.117 & 0.123 & 0.185 & 0.078 & 0.171 & 0.114 \\
\hline $\mathrm{Ce} / \mathrm{Ce} *$ & 0.362 & 0.717 & 0.860 & 0.384 & 1.127 & 0.405 & 0.726 \\
\hline Subbasin & Laingsburg & Laingsburg & Laingsburg & & & & \\
\hline Formation & Whitehill & Prince Albert & Prince Albert & & & & \\
\hline Sample & 14ZA102 & 14ZA103A & 14ZA103D & & & & \\
\hline La ppm & 44.214 & 45.126 & 19.653 & & & & \\
\hline Ce ppm & 92.329 & 95.041 & 37.831 & & & & \\
\hline Pr ppm & 10.700 & 10.931 & 4.681 & & & & \\
\hline Nd ppm & 39.322 & 41.370 & 17.235 & & & & \\
\hline
\end{tabular}




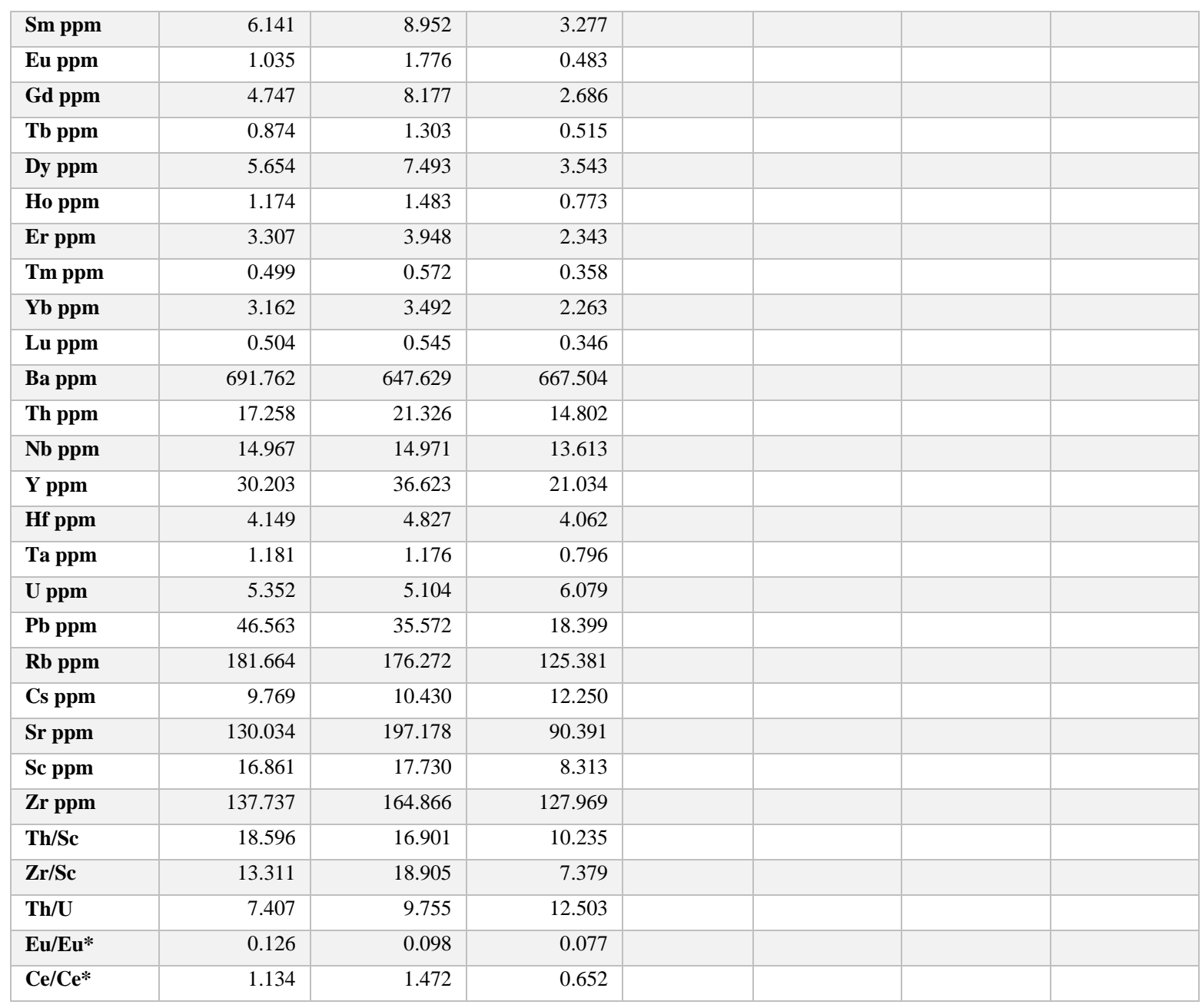

\section{Appendix IV}

\section{Sm - Nd Isotopes}

\section{Laingsburg Subbasin}

\begin{tabular}{|l|r|r|r|r|r|r|}
\hline Sample & 14za103D & \multicolumn{1}{|l}{ 14za107 } & 14za99B & 14za105B & 14za108 & 14za105A \\
\hline Sm ppm & 2.9 & 3.17 & 7.39 & 6.6 & 5.68 & 6.8 \\
\hline Nd ppm & 15.81 & 24.3 & 41.2 & 35.8 & 31.1 & 30.9 \\
\hline $\mathbf{1 4 7 S m / 1 4 4 N d ~}$ & 0.1108 & 0.079 & 0.1085 & 0.1115 & 0.1104 & 0.1328 \\
\hline $\mathbf{1 4 3 N d / 1 4 4 N d ~}$ & 0.512327 & 0.512229 & 0.512273 & 0.512197 & 0.512268 & 0.512282 \\
\hline $\mathbf{2 s}$ & 0.000004 & 0.000002 & 0.000003 & 0.000003 & 0.000002 & 0.000002 \\
\hline Epsilon Nd & -6.06665912 & -7.97833949 & -7.12003402 & -8.60256165 & -7.21756873 & -6.94447154 \\
\hline Tchur & 552591857.3 & 530414776.5 & 631465243.4 & 789404679.6 & 654159794.6 & 849502025.3 \\
\hline fSm/Nd & -0.43670564 & -0.59837316 & -0.44839858 & -0.43314692 & -0.4387392 & -0.32486019 \\
\hline
\end{tabular}

